\title{
Ulil norden
}

Nature Interpretation for Children and Young People in the Nordic Countries 

4 norden 



\section{Nature Interpretation for Children and Young People in the Nordic Countries}

Mette Aaskov Knudsen and Poul Hjulmann Seidler (Editors) 
Nature Interpretation for Children and Young People in the Nordic Countries

Mette Aaskov Knudsen and Poul Hjulmann Seidler (Editors)

ISBN 978-92-893-2549-3

http://dx.doi.org/10.6027/TN2013-534

TemaNord 2013:534

(C) Nordic Council of Ministers 2013

Layout: Hanne Lebech

Cover photo: Mette Aaskov Knudsen

This publication has been published with financial support by the Nordic Council of Ministers. However, the contents of this publication do not necessarily reflect the views, policies or recommendations of the Nordic Council of Ministers.

www.norden.org/en/publications

\section{Nordic co-operation}

Nordic co-operation is one of the world's most extensive forms of regional collaboration, involving Denmark, Finland, Iceland, Norway, Sweden, and the Faroe Islands, Greenland, and Åland.

Nordic co-operation has firm traditions in politics, the economy, and culture. It plays an important role in European and international collaboration, and aims at creating a strong Nordic community in a strong Europe.

Nordic co-operation seeks to safeguard Nordic and regional interests and principles in the global community. Common Nordic values help the region solidify its position as one of the world's most innovative and competitive.

Nordic Council of Ministers

Ved Stranden 18

DK-1061 Copenhagen K

Phone (+45) 33960200

www.norden.org 


\section{Content}

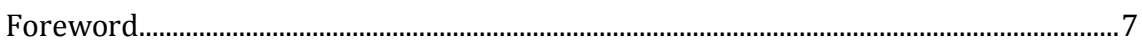

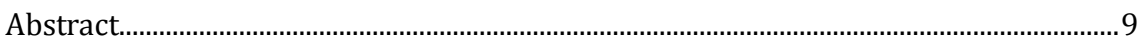

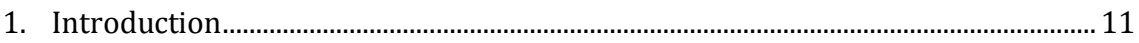

1.1 Project Description .................................................................................................... 11

1.2 The Aim of the Project ............................................................................................ 12

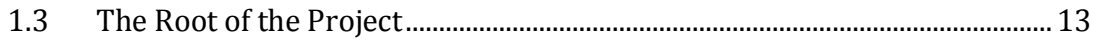

$1.4 \quad$ Project Background ........................................................................................... 15

1.5 Project Course.......................................................................................................... 21

2. Seven Central Perspectives in Nordic Nature Interpretation that can contribute to an Increased Understanding of Nature and Sustainable

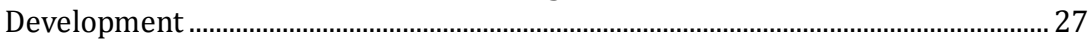

$2.1 \quad$ Nature Interpreters as Facilitators ……............................................................ 27

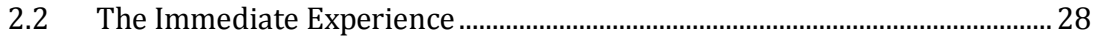

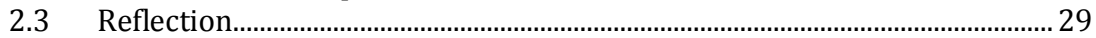

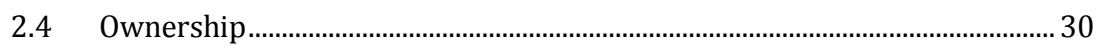

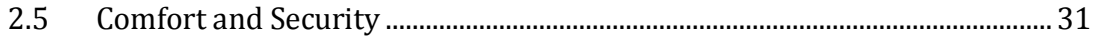

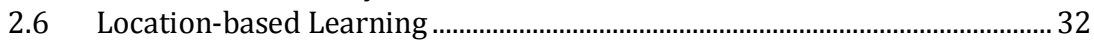

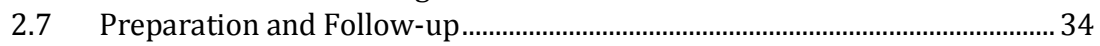

3. An Overview of Good Examples of Nature Interpretation in Nordic countries............. 35

3.1 Nature Interpreters as Facilitators ................................................................. 37

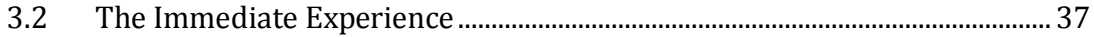

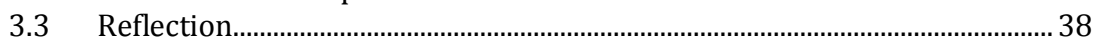

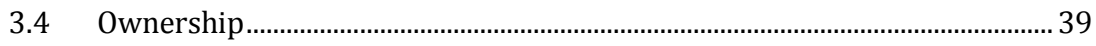

3.5 Comfort and Security ……............................................................................. 40

3.6 Location-based Learning ........................................................................... 41

3.7 Preparation and Follow-up.............................................................................. 42

4. Make a Lasting Impact with Your Nature Interpretation - Enhance the

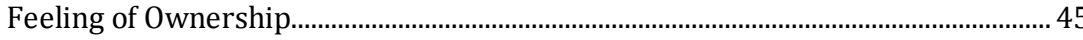

4.1 Getting a Feeling of Ownership of Things....................................................... 45

4.2 Getting a Feeling of Ownership of an Idea and Something We Don't

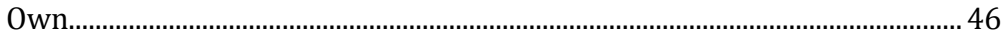

4.3 As a Nature Interpreter You Have Full Ownership - But What About Your Guests?......................................................................................... 46

4.4 The outcome for your visitors is not only about what they

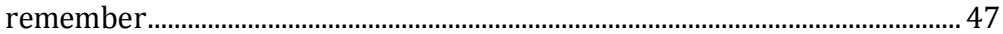

4.5 Ownership Relating to a Conservation Issue.................................................. 47

4.6 Mechanisms that Develop Feelings of Ownership.......................................... 47

4.7 How to Develop Understanding and Ownership of Sustainable

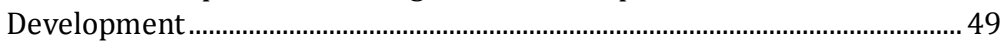

4.8 Time is Always the Limit.............................................................................. 51

4.9 Literature 
5. The Demanding Role of Nature Interpretation Sites ................................................ 55

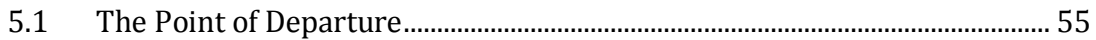

5.2 The Role of Nature Interpretation Sites in the Nordic Arena......................... 56

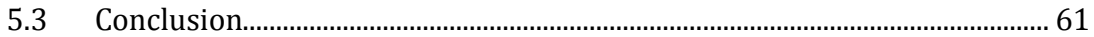

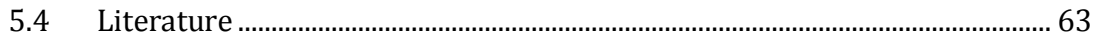

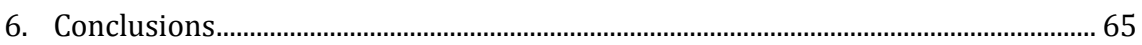

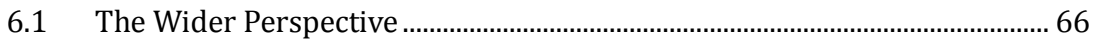

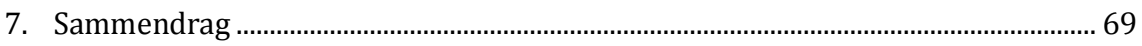

8. Appendix A/Bilag A ....................................................................................................... 71

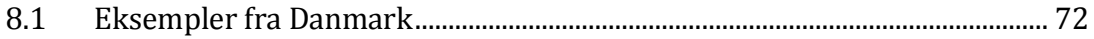

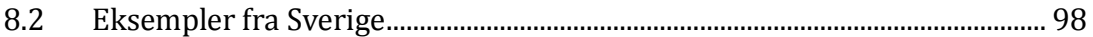

8.3 Eksempler fra Norge ........................................................................................110

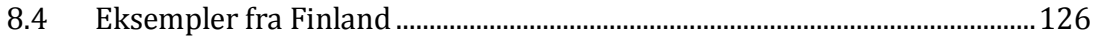

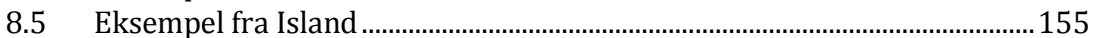

8.6 Eksempler fra Færøerne..............................................................................156

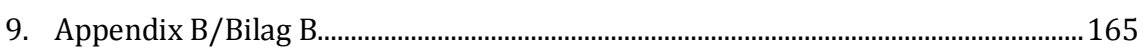

10. Appendix C/Bilag C....................................................................................................... 167

10.1 Workshop in Östersund $17^{\text {th }}-19^{\text {th }}$ September 2012...................................167

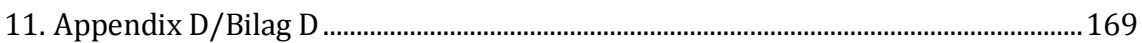




\section{Foreword}

Just as I had found my feet as a nature interpreter for children, this workshop gave me so many new thoughts and ideas. It was a good job that Søren, at the meeting, said that it's better to try to improve oneself incrementally, rather than trying to revolutionise one self and starting over. Build on what you have already - that's better in the long run. (Michaela from Sweden).

It was a great experience to sit with each other's activities and provide input, but in this process one is caught up in other people's work, so it got under my skin, and I'm finding that I can use them myself. Next time more time should be dedicated to this ... but it was also really good to get everything cleared up when talking to the specialists ... (Vibe from Denmark)

The above quotes are from two nature interpreters, who participated in the Nordic Workshop for Nature interpreters in Sweden, September 2012. They provide a clear picture of how the project "Nature Interpretation for children and young people in the Nordic countries" achieved one of its central goals - to create an effective framework in which nature interpreters can share positive experiences and inspire each other's mediation in practice.

Another central goal of the project has been to create an overview of methods that further the development of nature interpretation for children and young people in the Nordic countries. The project is a collaboration between 25 active nature interpreters, the project steering committee of 10 members and scientists from relevant Nordic research institutions. The project was realised with a grant from the Terrestrial Ecosystem Group (TEG) under the Nordic Council of Ministers. The participating countries were Denmark, Sweden, Norway, Finland, Iceland and the Faroe Islands. 



\section{Abstract}

Nature Interpretation for Children and Young People in the Nordic Countries was a one-year project with all of the Nordic countries participating. The project was realised thanks to a grant from the Terrestrial Ecosystem Group under the Nordic Council of Ministers. The primary goal of the project was to collect, develop and mediate a series of good examples of how nature interpretation, aimed at children and young people, can encourage children's understanding of nature, and inspire them to involve themselves with questions on humans nature and thus help contribute to sustainable development. The project focused on a several points of view regarding the planning of nature interpretation activities, which are central considerations when nature interpretation aims to lead to sustainable development. These points of view are concerned especially with how nature interpreters, through their activities, can instil a sense of ownership in children and young people, that involves body and mind, and encourages reflection and puts the experience and the activities in nature into a wider context. 



\section{Introduction}

\subsection{Project Description}

To implement sustainable management of our nature and culture environments, it is necessary to have knowledge of it and engage with it. This is the foundation of environmental politics in the Nordic countries. Nature interpretation is an important tool when citizens, children as well as grown-ups, are to acquire knowledge of and opinions on our nature and environment. One important goal of nature interpretation in the Nordic countries is to encourage the public to participate in the environmental debate. It is especially important to inspire interest among children and young people, as they are the citizens of the future, and future stewards of nature and the environment.

Nature interpretation takes place in the landscape. Outdoor life, physical activity and close contact with the landscape, the diversity of nature and cultural heritage monuments are important elements in nature interpretation. Furthermore, it is also the aim of nature interpretation to promote a healthy and sustainable lifestyle for the population at large.

\section{Figure 1.1}

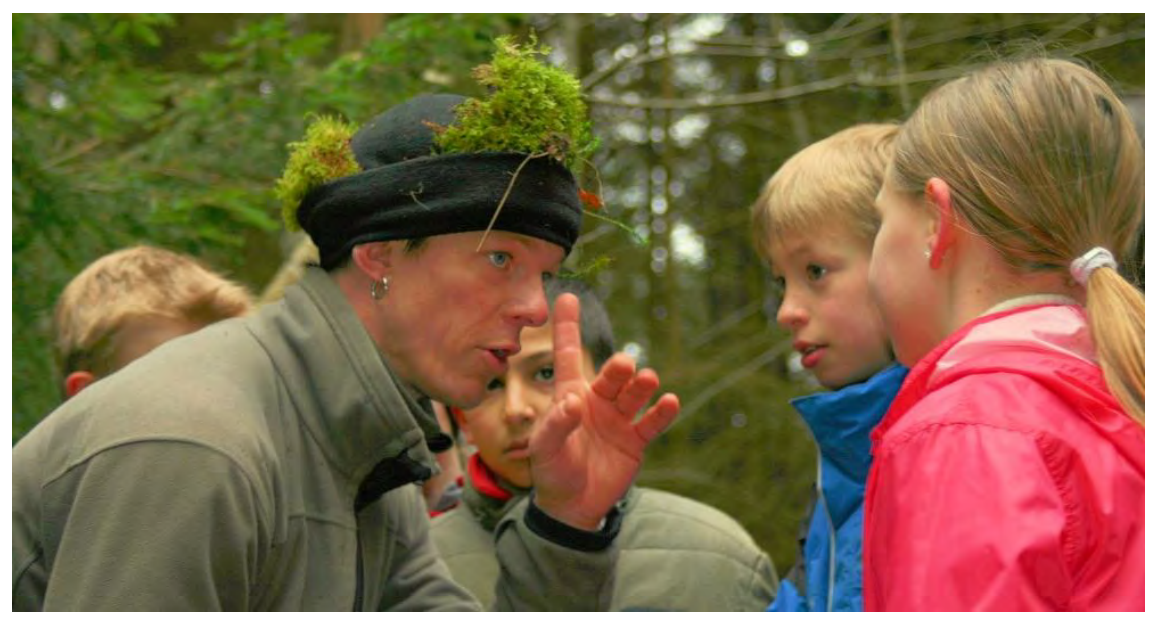

Photographer: Mette Aaskov Knudsen. 


\subsection{The Aim of the Project}

The overall aim of this project was to develop nature interpretation for children and young people in the Nordic countries in connection to periurban areas, natural areas and cultural environments.

This was achieved by highlighting a series of interesting practical examples of nature interpretation aimed at children and young people in the five Nordic countries. These examples was developed on and nature interpretation methods will be mediated to nature interpreters, and other relevant teaching environments, in the Nordic countries.

The secondary aim of the project was to build on nature interpretation as a method with which to inspire joy in children and young people at being, and expressing themselves, in nature. At the same time, an understanding of the relationship between people, nature and culture environments is to be created. It is thus the intention that children and young people are motivated to practice having a say and participating in the democratic processes that surround the use and mediation of nature and culture environments.

Furthermore, the project had the following sub-aims:

- To inspire a general lift in the quality of Nordic nature interpretation, which is to support, promote and elevate the skills and learning of the intended demographic. This is achieved with reasons for, as well as discussion and application, of the theory and practise worked with for this project.

- For nature interpreters participating in the project, it is the aim that they and their workplace are inspired to develop their own methods and skills.

Through discussions with and contributions from experienced nature interpreters, trained experts and the steering group of the Nordic project, we have pointed out seven areas that we have found to be especially important to address, in order to promote skills to engage oneself in the management and use of our nature and environment.

We have chosen to focus on:

- The democratic aspect.

- Ownership among participants.

- Nature interpreters role as facilitators. 
We are aware that not all of these areas apply to all demographic categories at all times, but we hope and believe that more areas can be incorporated in the context within which nature interpretation takes place.

We thereby hope that the quality of nature interpretation can be raised through explanation and use of the theory and practice that is worked with throughout this project.

From a Nordic perspective, and in relation to the management of our nature and environment, we have come up with a philosophy and a point of departure that characterises qualified nature interpretation in the Nordic countries in 2012.

\subsection{The Root of the Project}

The aim of the project is inspired by the following strategies and programmes that were prepared by the auspices of the Nordic Council of Ministers. ${ }^{1}$

- The Nordic Miljøhandlingsprogram 2009-2012 (Environmental Action Programme), focussing in particular on the goals highlighted in 3.2. Landscape, culture environment and outdoor life. In Miljøhandlingsprogrammet it is explicitly stated that the Nordic Council of Ministers will work towards increasing public knowledge of the importance of landscape and cultural heritage in its relation to a high quality of life.

- In Strategi for arbeidet med friluftsliv (2010) (Strategy for work related to outdoor life) from the Nordic Council of Ministers' taskforce TEG, point 2.2.4. Friluftsfostran focuses especially on promoting children and young people's opportunities for taking part in outdoor life, both in nature and in peri-urban natural areas.

\footnotetext{
${ }^{1}$ The following references were used in The root of the project: COPE: http://www.norden.org/da/publikationer/publikationer/2007-586.

Miljøhandlingsprogram 2009-12 : http://www.norden.org/da/publikationer/publikationer/2008-733 TEG's friluftsstrategi: http://www.norden.org/da/nordisk-ministerraad/ministerraad/nordiskministerraad-for-miljoe-mr-m/institutioner-samarbejdsorganer-ogarbejdsgrupper/arbejdsgrup per/arbejdsgruppen-for-terrestriske-oekosystemer-teg/arbejdsprogram Strategi for børn og unge i Norden: http://www.norden.org/da/publikationer/publikationer/2006-718 Den europæiske landskabskonvention: http://www.naturstyrelsen.dk/NR/rdonlyres/88F78D6C-8DBA4B1F-9A14-F5A0381C5BA6/120126/EUROPAEISKLANDSKABSKONVENTION1.pdf
} 
- Strategi for barn og unge i Norden (2010) (Strategy for children and young people in the Nordic countries) has a vision that "children and young people should be able to influence their own lives, their immediate environment and the development of society as a whole," prioritising the environment, on which it is stated that: "A

collaboration that creates more value through an exchange of experiences among children and young people in the Nordic countries, and that strengthens their awareness of the value of nature and its resources."

- COPE - Children, Outdoor, Participation, Environment (Norden 2008) deals with ideas of learning that can engage children and young people in the areas of health, nature interpretation, environmental issues, democracy and participation.

This project is also informed by the European Landscape Convention, where knowledge on landscape, home rule, involvement and commitment are central aims.

Konventionen for den immaterielle kulturarv (UNESCO 2003) (The Convention for Immaterial Cultural Heritage) defines cultural heritage as "Customs, creations, expressions, knowledge and skills and tools and appertaining equipment, artefacts and cultural spaces that society, groups and in some cases individuals perceive as a part of their cultural heritage. This immaterial cultural heritage, passed down from generation to generation, is recreated continuously in relation to their surroundings, their reciprocal relationship to nature and their history, and creates a sense of identity and continuity. It promotes respect for diversity and human creativity."

There is therefore a strong political will and backing for the aim of this project. Nature interpretation in the Nordic countries is a considerable factor in achieving the goals set by the many relevant strategies and conventions. Furthermore, nature interpretation has great potential to develop further in these directions, drawing more attention to the methods of Nordic nature interpretation. 


\subsection{Project Background}

\subsubsection{Nature Interpretation in the Nordic Countries: A Historical Review}

Nature interpretation as a method of mediation was initiated throughout the Nordic countries in the late 1980s and 1990s. The report "Naturveiledning i Norden" (Nord 1990:52) (Nature interpretation in the Nordic countries) was a result of this joint effort. A common Nordic definition of nature interpretation was devised as an integral part of the Nordic joint effort.

\footnotetext{
"Nature interpretation is the mediation of an outlook on and knowledge of nature. The goal of nature interpretation is to create an understanding of fundamental ecological and cultural interconnections, as well as people's role in nature. Through nature interpretation, positive experiences are created that can increase environmental awareness, both for individuals and for society as a whole" (freely cited from Nord 1990:52).
}

Already then it was maintained that nature interpretation contributes considerably to both positive experiences in nature, and inspires an increased environmental awareness in both individuals and society. The ultimate goal of nature interpretation is to influence people's relationship to nature; to increase environmental awareness and give individuals an opportunity to contribute to sustainable development.

Aside from the definition of Nordic nature interpretation, the project group agreed then that nature interpretation can contribute towards realising the following goals:

1. Provide inspiration for outdoor life on nature's own terms and in accordance with Nordic traditions for outdoor life.

2. Counter disturbances in and damage to vulnerable natural areas.

3. Promote understanding for the necessity of different forms of protection of nature and the environment.

4. Contribute to a mutual understanding between the primary professions and practitioners of outdoor life.

5. Promote understanding of how people, in a cultural-historical perspective, have had influence on and exploited nature and its resources.

6. Spread knowledge of how human activity affects eco systems

7. Promote a societal development in which there is a balance between nature and its exploitation. 
Following the release of the 1990 NORD-report, Denmark, especially, continued to develop nature interpretation as a strong method and profession over two decades that followed. In the middle of the first decade of the 2000s, initiatives were taken in Norway, Sweden and Iceland to strengthen nature interpretation. In Finland, nature interpretation became an important part of practice connected to the task of managing national parks and nature reserves in Forststyrelsen (Metsähallitus). In Sweden, the Swedish Centre for Nature Interpretation (SCNI) was established at the Swedish University of Agricultural Sciences (SLU) in 2008, and in Norway a new unit for nature interpretation at the Norwegian Nature Inspectorate/the Norwegian Directorate for Nature Management was established in 2010. New policy documents for work related to nature interpretation were also signed in both Sweden and Norway. In all of the Nordic countries, children and young people are an especially important and central demographic target for nature interpretation.

\subsubsection{A New Nordic Joint Effort}

There has always been a decent and equal working relationship between the Nordic countries in the field of nature interpretation. The Nordic countries have inspired and helped each other. In 2009, a group of people from the Nordic countries had an idea to strengthen the countries' cooperation with closer and more formalised cooperation. The aim was to work together on ideas for and developing projects on relevant challenges facing nature interpretation today.

The group that took initiative for this project came from Sweden, Denmark, Norway, Finland, Iceland and the Faroe Islands. The persons involved in the group are:

- Denmark: Mette Åskov Knudsen (project leader) and Poul Hjulmann Seidler from the Centre for Outdoor Life and Nature Interpretation at the University of Copenhagen.

- Norway: Torfinn Rohde and Brita Homleid-Lohne the Section for Nature Interpretation at the Norwegian Nature Inspectorate.

- Sweden: Eva Sandberg and Per Sonnvik from the Swedish Centre for Nature Interpretation at the Swedish University of Agricultural Sciences.

- Finland: Carina Wennström from Metsähallitus/Forststyrelsen and Niina Mykrä from the Association of Finnish nature- and environment schools.

- Iceland: Ragnar Kristjánsson from the Agricultural University of Iceland.

- The Faroe Islands: Trondur Levinsson from Umhvørvisstovan, Environment Agency. 
Figure 1.2. The project's steering group gathered for a planning meeting in Tyresta Nationalpark, Sweden in March 2012

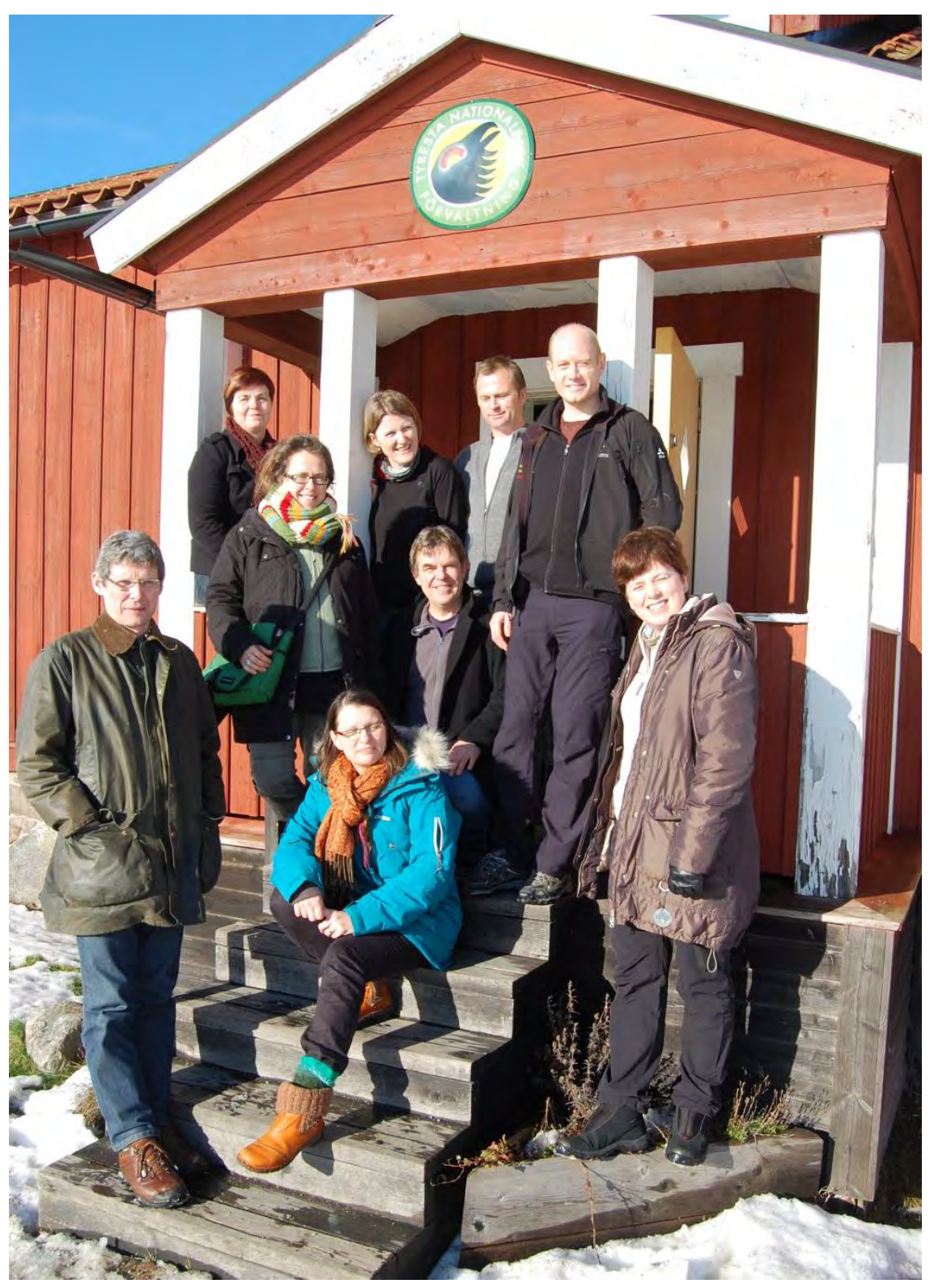

Photographer: Brita Homleid-Lohne. 


\subsubsection{The State of Nordic Nature Interpretation in 2012}

\section{Sweden}

The Swedish Centre for Nature Interpretation (SCNI) was established in 2008-an initiative by the Swedish Environmental Protection Agency (SEPA) and the Swedish University of Agricultural Sciences (SLU). The aim was to develop nature interpretation in Sweden. The point of departure for the work is the broad definition of nature interpretation that the Nordic Council of Ministers agreed on in 1990. SCNI gathers a network of 1,500 interpreters and others, who are interested in SCNI's work. SCNI promotes knowledge and experience by coordinating the network, organising seminars and courses and spreading best practice. An overview of nature interpretation activities has been prepared, indicating great diversity in different forms of nature interpretation in Sweden. Some of the main players in the field of nature interpretation are naturum (nature information centres and Nature Schools), nature tourist organisations, nature protections unions, homestead associations and a collection of public bodies. The most common forms of nature interpretation are guided tours and information in the form of Interpretive panels, leaflets and exhibitions.

SCNI's reason for participating in this project is to improve on the skills needed to best mediate nature interpretation to children and young people in Sweden, through a joint effort from the Nordic countries. Furthermore, SCNI wishes for the work to create a greater overview of good examples of nature interpretation, that can serve as a basis for further understanding and development of nature interpretation - not just nationally, but also throughout the Nordic countries. SCNI will use the results of the project in the on-going work with seminars, courses and conferences for nature interpreters in Sweden. It is SCNI's hope that these activities will help further elevate the standard of nature interpretation for children and young people in Sweden, raising awareness of nature and the value of the cultural landscape among the people of Sweden, encouraging the public to support and participate in environmental protection.

\section{Norway}

Historically speaking, nature interpretation in Norway has had a strong connection to Norwegian traditions of outdoor life. Today, nature interpretation in Norway is defined as an activity in its own right, with a strong focus on the educational aspect, the experience of nature, knowledge of nature, nature culture and mediation of views relating to nature and environment. Nature interpretation most often takes place outside facilitated by a single person - the nature interpreter. Nature interpreters in Norway work in voluntary unions, grass root organisa- 
tions, in museums, in outdoor life councils, at nature information centres and camps and within the tourist industry. Since 2007, Statens Naturoppsyn (SNO) has had nature interpreters on staff in its nature interpretation section.

Plans are in the works to establish a Norwegian network for nature interpreters, and more colleges/universities are working towards making degrees and courses on nature interpretation a reality. SNO's reasons for participating in this project are multifaceted:

- To provide nature interpreters in Norway with an opportunity to establish professional contact with nature interpreters in the other Nordic countries.

- To contribute to the exchange of experiences with nature interpretation for children and young people between Nordic nature interpreters.

- To strengthen the Nordic cooperation between the people and institutions that work with the development of nature interpretation as a profession and field of research in the other Nordic countries.

\section{Iceland}

In Iceland there are 15-20 people that work with nature protection. A lot of these also work as nature interpreters. During the summer, approximately 50 nature guards (nature interpreters) work in three national parks and 15 natural areas, as well as in the municipality of Reykjavík. The reason for hiring nature guards (nature interpreters) is tourism in the Icelandic nature: mass tourism is a problem in the vulnerable Icelandic nature, and professional nature interpreters are therefore necessary.

Nature interpretation for children and young people is scarce and isn't prioritised by the nature protection authorities. The municipality of Reykjavík runs a nature school, with an appropriately qualified person, who provides in-service training/further education for secondary school teachers. It is difficult to compare nature interpretation in Iceland to that of the other Nordic countries, especially because of differences in the education of nature interpreters. The Environment Agency of Iceland provides two-week courses for nature guards (nature interpreters). Young university students make up approximately $90 \%$ of the people that complete the course and are granted permission to work as nature guards (nature interpreters). They work predominately in national parks for six to ten weeks for two to three summers. A large part of their summer work is guiding tourists through protected nature sites. 


\section{Finland}

Many different authorities and institutions in Finland can offer nature interpretation: Nature and environment schools, youth and outdoor life centres, nature information centres, WWF, the association for nature protection, $4 \mathrm{H}$ and more. The demographics catered to are everyone from young children to adults, depending on the institution and organisation, but the goals are the same. In connection with the establishment of Finland's nature and environment schools, an idea to build a support network for environmental teaching in children's institutions, schools and youth schools was formed. Thus, the LYKE network was founded in 2011. The network consists of nature and environment schools, Metsähallitus (Finland's forest agency)'s nature information centres, national youth centres and camp school centres. The long-term aim is for all institutions and schools in Finland to have a connection to a place where they can get help and inspiration for education concerning the environment.

All of the network participants have the same ideas and goals: Working with institutions and/or schools is a central part of the task, and practical activities in nature and holistic experiences, and a diverse application of the senses are a part of the learning approach. The coordination of the network opens up for possibilities of development, where participants can help and inspire each other, and where it will be possible to organise courses and meetings with professional content. The Finnish Ministry of Education and Culture is responsible for this initiative.

Nature interpreters in Finland and within the new LYKE network find it inspiring to hear how nature interpretation is organised in the other Nordic countries. Furthermore, it is useful to share important educational approaches in nature interpretation. It is important to make contact and connect with other countries to learn how they work with developing their nature interpretation in practice.

\section{Denmark}

Over the past three decades in Denmark, the interest and persistent development of the education, in-training and rooting of nature interpreters has taken a steady climb. This effort has brought about a greater awareness of nature interpretation among the Danish population, as well as a development within nature interpretation that promotes a broad selection of societal needs. This includes needs for information on and protection of nature and culture environments, support for primary and secondary school pupils' education within most subjects, stimulation of social and human development for young children, actions that promote physical and mental health for several demographic categories, the inclusion of vulnerable children, as well as experience economy and 
the development of tourism. Approximately 350 full-time nature interpreters work predominantly at nature centres, nature schools, green organisations, museums, the Danish Nature Agency and as independent nature interpreters.

Aside from nature interpreters and their workplaces, the developing of nature interpretation in Denmark is promoted by, among other things, the nature interpreter course (a two-year training course consisting of seven residential courses of a two-to-ten day duration, as well as three large assignments). Furthermore, over the years there has been a special focus on on-going development and further education in seminar workshops, regional networks and national theme-networks. A good and long-term joint effort from central interest groups such as the Danish Outdoor Council, the Danish Nature Interpretation Service and the Danish Rangers Association have all contributed to furthering this development, like the Danish Nature Interpretation Service vast support to the Nature Interpretation education in the past, and the Danish Outdoor Council's past and present support for wages, education and further training has been paramount for the success of nature interpretation. This has supported a staff comprising of both dedicated and professional nature interpreters. Denmark's motivation for participating in this Nordic project is to strengthen the network between the different participants working with nature interpretation - a network of nature interpreters, but also a strengthened network between people in the Nordic countries that work with coordination, development of skill and network support.

\subsection{Project Course}

The aims of the project was realised by using examples of interesting practice within nature interpretation, aimed at children and young people in the Nordic countries. These examples highlight immediate and outdoor education. Each example has been described in such a way that it is clear which demographic it is aimed at, and thus what methods of mediation are applicable. In order to fulfil the part of the aim that concerns itself with the democratic aspect and opportunities to influence nature management, several examples are related to how advice and information includes and involves participants and gives them a chance to act or make decisions on their own.This project has focused on three areas within which the examples take place: The peri-urban environment, protected natural areas and culture environments. In all three 
areas, the examples are to highlight the connection between people, culture and nature. The examples are about nature interpretation aimed at children in schools, and also children and young people in other contexts like children within the family, or children and young people in their spare time.

\subsubsection{Planning Workshops for Nature Interpreters in the Nordic Countries, March-September 2012}

To collect interesting examples of nature interpretation in practice, the steering group laid out a project plan during its first meeting, describing sub-elements and how to achieve the project aims.

February 2012: The project steering group meets in Tyresta National Park in Sweden to plan. An invitation is prepared, and a form for nature interpreters to fill out to make their interest in participating in the project known. The form covers which of the three areas (see above) and which demographic the examples deal with.

April 2012: Each country announces the chance to take part in the workshop to its nature interpreters. From the suggestions and applications received, members from the individual country's steering groups selected those most interesting and relevant to the project. A total of approximately 80 interested nature interpreters applied, from which 25 were selected to take part in the Östersund workshop. The list of all received examples can be seen at Swedish Center for Nature Interpretations homepage.

May 2012: The selected nature interpreters are informed of the decision and are invited to participate in the workshop in September 2012 in Sweden.

June 2012: Presenters at the workshop in September are contacted. A final framework for the project report is prepared. The invited nature interpreters submit their final example descriptions. Central perspectives of nature interpretation are emphasised in the descriptions that nature interpreters have to consider when they describe their examples. The emphasised perspectives are:

- Nature interpreters as facilitators.

- The immediate experience.

- Reflection.

- Ownership.

- Security and comfort.

- Location-based learning.

- Preparation and follow-up. 
The seven central perspectives in nature interpretation are described and discussed in detail in Chapter 2.

August 2012: The workshop programme is sent to all participants. This and the list of participants can be seen in Appendices B and C.

\section{Figure 1.3}

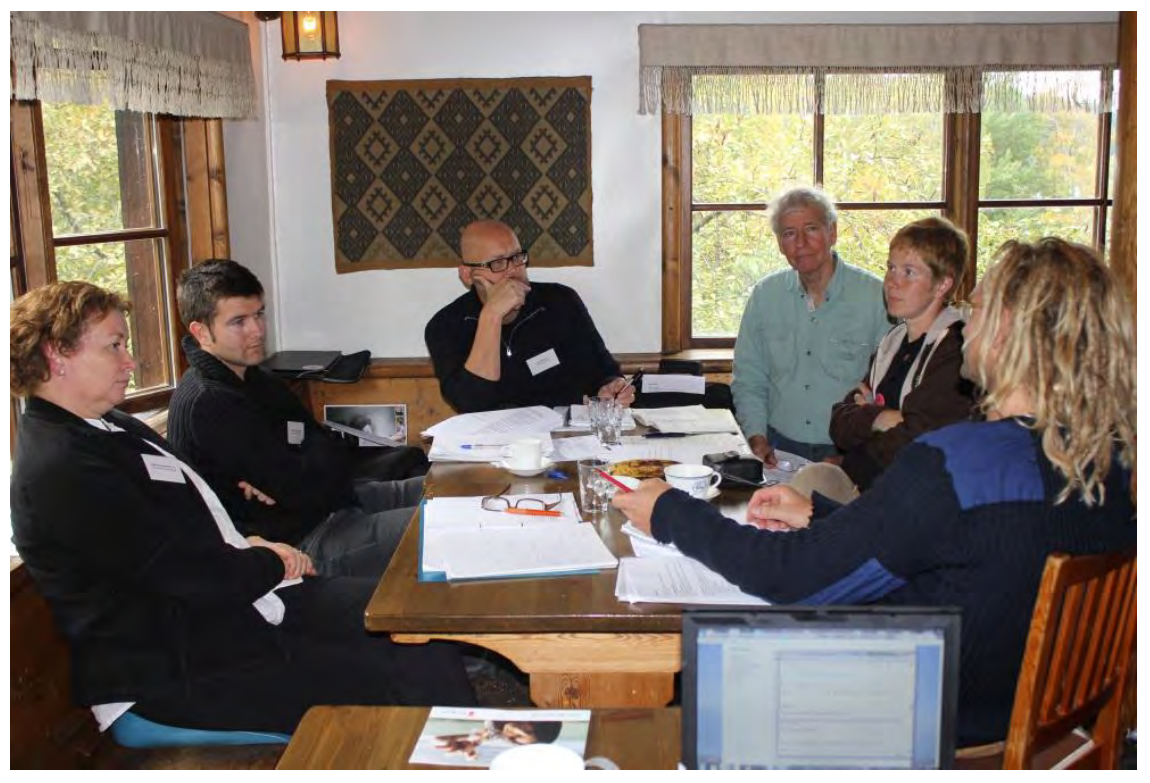

Photographer: Mette Aaskov Knudsen.

\subsubsection{Workshop in Östersund, Sweden $17^{\text {th }}-19^{\text {th }}$ September 2012}

A central component of the project was the joint Nordic workshop in Östersund, Sweden with a group of participants consisting of three-tofive nature interpreters from each of the Nordic countries. The aim of the workshop was to collect and develop 20-30 interesting examples of Nordic nature interpretation. To give them extra inspiration and knowledge for the developing process, two experts of the didactics of natural science and pedagogy took part: Søren Breiting, Lecturer in Curriculum Research at Aarhus University, Denmark and Lili-Ann Wolff, Lecturer at the Department of General Education at Åbo Akademi University, Finland.

Their role was to come up with an hour-long presentation, observe the discussions in the task groups, provide input to the task groups and lead the collective discussion based on the group work. Furthermore, both have contributed with an article included in this report. These two 
articles explore the themes that are particularly relevant for the aims of this project (see Chapters 4 and 5 in this report).

Parallel to the development of examples, the steering group had formed a small task group whose aim it was to discuss how nature interpretation can lead to sustainable development, focusing in particular on what elements are important to master for the mediation of nature interpretation in this context. It is on the basis of this, as well as running discussions within the steering group, that this report contains a chapter on nature interpretation that leads to sustainable development (see Chapter 2).

At the workshop, the participants were split into smaller groups of varied nationalities, with an aim to discuss, clarify and develop examples. Presentations and collective exhibitions were also there to inspire the group work. All of the completed examples can be seen in Appendix A. The method the group used during the workshop is described in Appendix D.

\section{Figure 1.4}

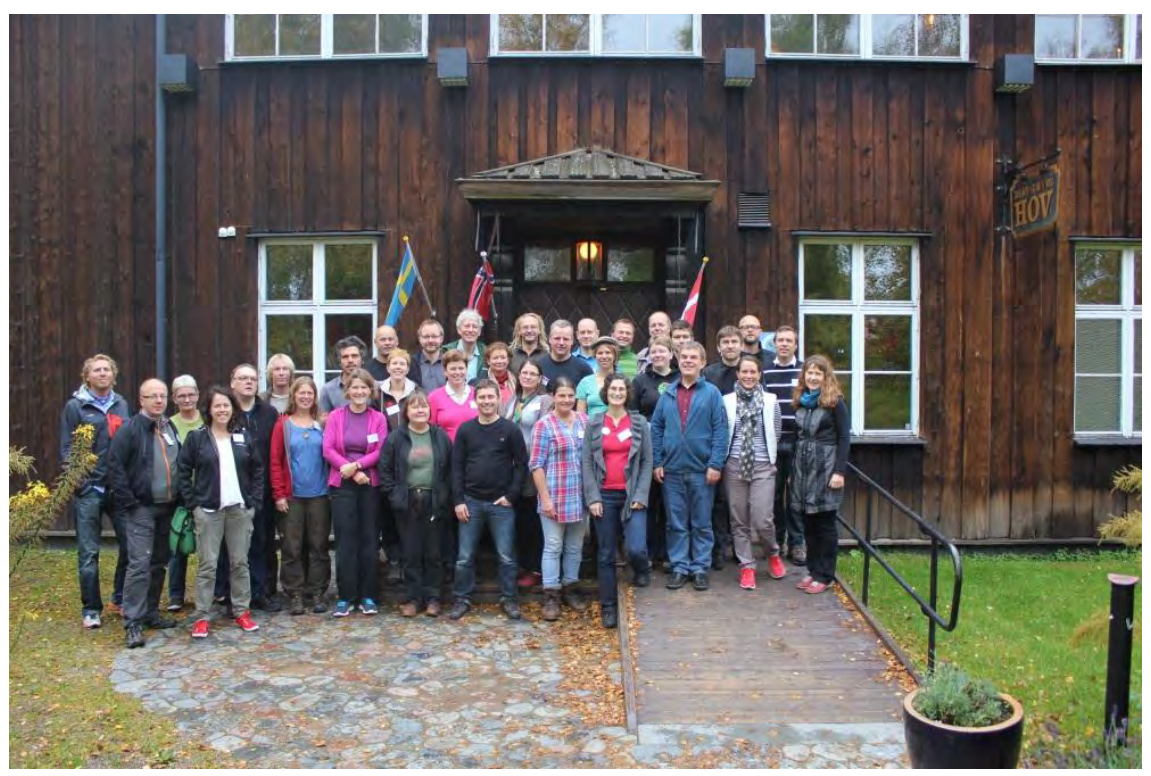

Photographer: Mette Aaskov Knudsen. 


\subsubsection{Course of Project after Workshop September- December 2012}

October 2012: Writing and editing of report commences.

The nature interpreter's example descriptions are collected and the speakers from the workshop complete their articles for the report.

November 2012-February 2013: The draft report is sent to the steering group for comments.

The steering group meets for a concluding three-day work seminar in Finland in November to work on the collection from the workshop and the project report.

The project administration completes a draft for the report, which is sent off to be approved or commented on by the entire project group, after which this report was completed. 



\section{Seven Central Perspectives in Nordic Nature Interpretation that can contribute to an Increased Understanding of Nature and Sustainable Development}

One aim of the project is to inspire a lift in the quality of Nordic nature interpretation - a lift that can support, promote and improve learning and skills of nature interpretation's target demographics.

Overall, nature interpretation deals with elements ranging from information and communication to participant involvement and facilitation, where all areas come into play. In terms of experience, the greatest challenge lies in operating within participant involvement and facilitating as crucial methods for improving learning for participants.

In this chapter, seven areas are described that we consider being crucial for working with the quality of Nordic nature interpretation. These considerations were made from the reflections of the steering group and discussions with the two participating experts Søren Breiting and LiliAnn Wolff, as well as the results of the Nordic workshop with 25 nature interpreters from all of the Nordic countries.

We are aware that not all areas apply to every audience at all times, but we think and hope that several of these (and as many as possible) can be adapted to any situation or context in which nature interpretation might take place.

\subsection{Nature Interpreters as Facilitators}

Considering the phrase "Teachers cannot teach anybody anything, but can create the circumstances under which pupils can teach themselves something" (Sten Larsen, Professor at the Department of Education at 
Aarhus University), the nature interpreter's role as a facilitator, who can establish a motivational framework and method of learning, becomes crucial for participants' learning. To possess the ability to facilitate the framework for learning to take place thus becomes important for nature interpreters to master.

Nature interpreters work in an arena that includes "meetings" between the participants, the informal classroom in nature and the many exciting possibilities, interests and dilemmas connected to the places of a nature interpretation tour. This arena presents particular challenges with, but also particular opportunities to create the right conditions to encourage participants' learning.

The facilitator role is fulfilled by a nature interpreter who is conscious of his/her own role, knowledge and views, and who facilitates views, opinions and discussions with an aim to encourage participants to reflect. This involves participant-orientated work methods that organises and establishes frames for learning processes, and that clarifies views and stimulates openness for the understanding of the views of others.

The nature interpreter can control and be aware of a continuum from a position where he/she is neutral and does not divulge his/her views, to a position as the expert within a field, who has strong and clear views, and where both positions make room for reflection among the participants. Thus a balance is created between the knowledge mediated by the nature interpreter, the standard of facilitation and the inclusion of the participants' own knowledge.

The overall question could be phrased as follows: "How does one facilitate so as to inspire participants to engage themselves in questions on nature and the environment, and let their voices be heard?"

\subsection{The Immediate Experience}

One of the strengths of the nature interpreter is the opportunity to work with the "immediate experience" with participants, including the immediate experience of meeting with what is happening out there, and the immediate experience of meeting the nature interpreter. It concerns itself with activities that are aimed towards the individual participant or the community (the group).

Nature interpretation can be set up in different ways, for example through actions, activities, dialogue, storytelling, games, drama and so on, and this provides different experiences. 
The experience is the individual participant's own impression, which through communication can articulate and clarify terms and feelings, and thus turn the experience itself into experience the participant has accrued.

The nature interpreter's communication can be supported with varied things like:

- Dialogue with and between the participants.

- Sensory experience followed-up on with communication.

- Plays, dilemmas, values and meaning with a concrete basis in the landscape.

- The unique possibilities of an individual place and the unique possibilities local areas present to local people.

Communication that purposefully takes its point of departure in the participant's own feelings, stories and personal experiences, is communication that works with episodic, narrative memory. Such a communication is an approach suited to help participants remember and retain what they experience.

In light of the above, the nature interpreter's choice of methods and the way these are presented, as well as the steering and way in which communication is facilitated, is crucial for the experience the participants takes away with them.

\subsection{Reflection}

Reflection is vital to retain experiences and impressions. It is important that it is seen in relation to already acknowledged knowledge and experiences. Reflection can help add surplus value to an experience and turn it into useful personal experience.

A visit provides opportunities for, and can stimulate, reflection, which links to one's own life and can have an impact on one's own story. The nature interpreter as facilitator steers reflection in a way that stimulates ownership (see the next chapter). If nature interpretation includes the participant, so that he/she will reflect in a way that has a long-term effect, it is more likely to lead to the participant taking responsibility and involving themselves in the management of nature and environment.

An interesting question for the nature interpreter could be: How do I get participants to think of the experience as something linked to their own future? 


\subsection{Ownership}

The more one is involved in and work for any given change, process or better result, the higher the level of mental ownership one feels towards it. This ownership creates a greater incentive and inclination to work for, follow up on and take active part in something.

The level of ownership felt therefore has an influence on a person's future commitment in situations or within areas that involve the person's feeling of ownership. There is a close bond between this understanding of ownership and the preservation and development of democracy, where a crucial element is the ability and chance to have an influence on one's own situation and to take part in decision-making.

Ownership and the ability to increase the capacity to have and to seek out influence on one's own situation can be practiced in nature interpretation in many contexts.

It can potentially happen every time participants are given an opportunity to have a say in decision-making during activities. This can, for example, happen when school pupils themselves have to teach or instruct other pupils, or when children and young people have an opportunity to make their own decisions concerning choice of method and activities (types of campfire, choice of bivouac, a location they choose themselves and like to be in etc.)

The question one could ask in relation to nature interpretation is: To what degree can we, as nature interpreters, be ready to involve our audience and let them have an influence on the activities? And what does it take to do so?

In Søren Breitings article "Make a lasting impact with your nature interpretation - enhance the feeling of ownership," which follows this chapter, he explains this notion of ownership in detail.

To promote and stimulate mental ownership in participants of nature interpretation, it is necessary for nature interpreters to understand their own role as facilitator and to have the ability to create valuable reflections as mentioned in the above paragraph. The nature interpreter's use of methods that stimulate participants' thinking and visualisation of the future can be an approach that promotes ownership and involvement. 
Figure 2.1

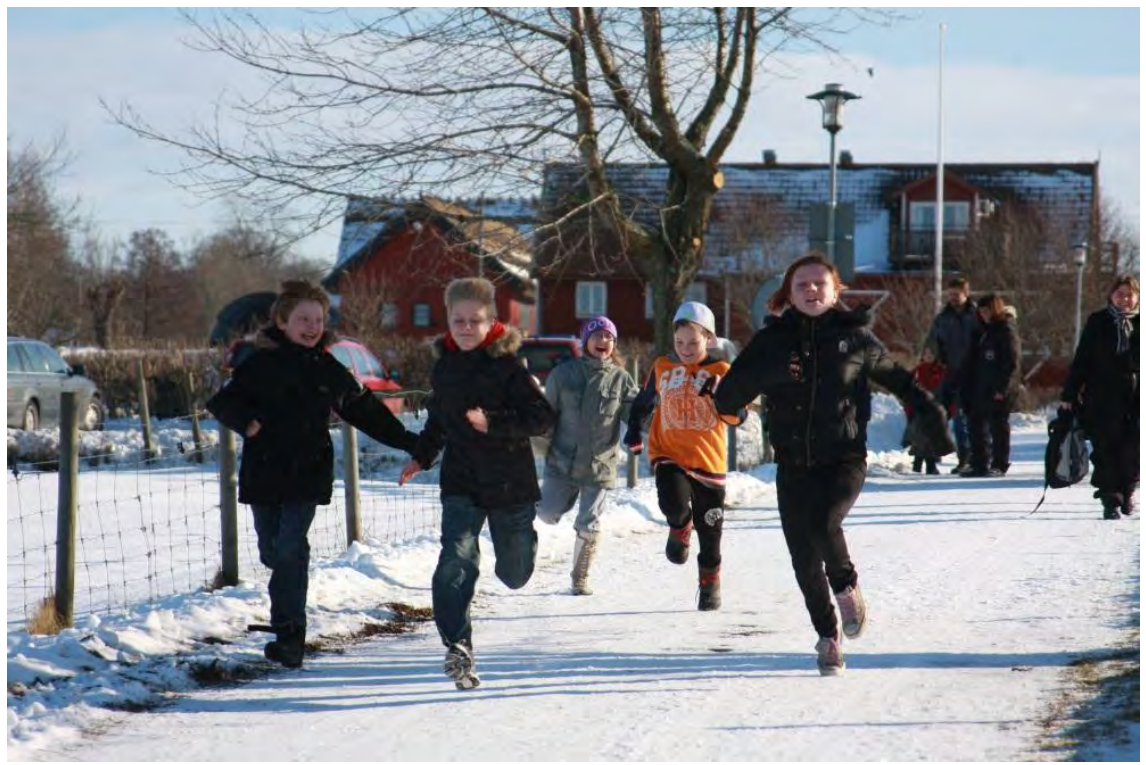

Photographer: Sofie Lindblom.

\subsection{Comfort and Security}

Comfort and security within the group is a deciding factor for the individual participant's well-being, and thus their desire to pay attention and concentrate. Conversely, discomfort can cause unease, insecurity and passivity. Comfort and security are important indicators for how we "feel in the world." Nature interpreters can help develop both the individual participant and the group's feeling of comfort and security in nature, and thus in meeting with the unknown and different.

It is important to consider how nature interpreters can develop and use relationship-building activities that promote a sense of comfort and security. This involves activities aimed at the individual or at the entire group, also in relation to the inner dynamics of the group.

"The facilitator must be comfortable - also comfortable with handling discomfort. This can be existentially thought-provoking and stimulating." 


\subsection{Location-based Learning}

The chosen area for nature interpretation activities makes for special opportunities. Every place has its own history, culture, stories and events. This provides an opportunity for participants to get special knowledge of and feelings connected to the place they are in. For example the development of feelings for, and identity in relation to, their own local or natural area. Methods that contribute to creating a relationship and interest to the place can help increase interest in engaging with nature and environmental questions, to preserve a protected nature site or develop the peri-urban nature environment. Thus, a place has a context: A culture, a connection to people, and a nature and an environment.

Questions that can be asked to create an understanding, develop opinions and create engagement in relation to "the future of the place" could be:

Who has lived here? What happened? Whose place is this? What can we do here? What are we supposed to do with this place?

"If one doesn't have knowledge of or feelings for one's own home, one will never take an interest in nature and culture areas elsewhere." Quote from the workshop in Sweden. 
Figure 2.2

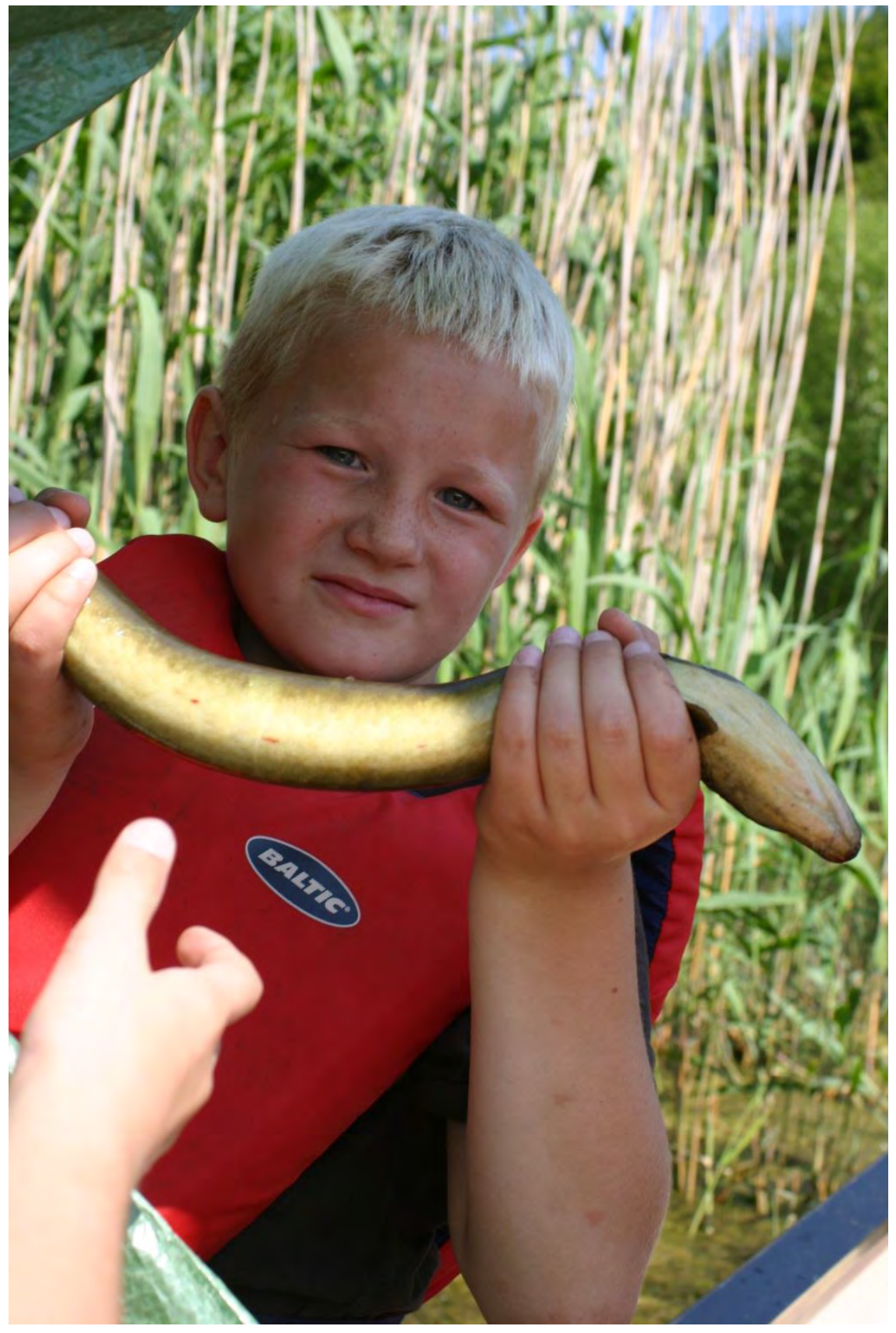

Photographer: Mette Aaskov Knudsen. 


\subsection{Preparation and Follow-up}

The outcome and yield of teaching very much depends on whether or not an event with a nature interpreter is integrated into the participant's daily learning or everyday life, ensuring that the visit and activities works in the context of a coherent learning course. This takes preparation for the visit and follow-up work.

It makes sense, for example, for a school class that participates in nature interpretation activities to visit the same nature interpreter several times as a part of a planned learning course. Here, teachers play a vital role. How can a nature interpreter best help teachers, so that they feel comfortable and prepared for the event, and so that their teaching is integrated before, during and after the visit?

\section{Preparation}

How can a group improve the visit so that they benefit more from it? Are there things that need to be researched before the visit? Literature to be read? Practical work to be done? How can preparation be seen as an interesting element that motivates pupils/children to engage with the activities?

\section{Good question for this part could be}

Where are they going? What knowledge do they require - what are their goals and expectations? What concepts would they like to know more about? What practical preparations would be good? How can data be used and retained?

\section{Follow-up}

What activities stimulate further work and reflection? Can the pupils take something tangible home with them? How can the arrangement be used in the context of the group's classroom and in their daily lives?

"Are there things in the other's daily life and situation that we tie into? Can we build bridges - emphasize with the expectations and purpose of another?" Quote from workshop. 


\section{An Overview of Good Examples of Nature Interpretation in Nordic countries}

One of the central aims of this project has been to collect and develop good and interesting examples of nature interpretation activities in the Nordic countries that can take place in one of three areas: Protected natural areas, peri-urban nature and/or culture environments. Furthermore, each example highlights one or more of the seven perspectives that can contribute to a better understanding of nature and contribute to sustainable development.

The following table presents each example in relation to areas and the seven perspectives: 


\begin{tabular}{|c|c|c|c|c|c|c|c|c|c|c|}
\hline EXAMPLES & $\begin{array}{l}\text { Peri- } \\
\text { ur- } \\
\text { ban }\end{array}$ & $\begin{array}{l}\text { Culture } \\
\text { environ- } \\
\text { viron- } \\
\text { ment }\end{array}$ & $\begin{array}{l}\text { Pro- } \\
\text { tected } \\
\text { areas }\end{array}$ & $\begin{array}{l}\text { Nature } \\
\text { interpre- } \\
\text { ter as } \\
\text { facilitator }\end{array}$ & $\begin{array}{l}\text { Imme- } \\
\text { diate } \\
\text { experi- } \\
\text { ence }\end{array}$ & $\begin{array}{l}\text { Re- } \\
\text { flec- } \\
\text { tion }\end{array}$ & $\begin{array}{l}\text { Comfort } \\
\text { and } \\
\text { security }\end{array}$ & $\begin{array}{l}\text { Owner- } \\
\text { ship of } \\
\text { activity }\end{array}$ & $\begin{array}{l}\text { Locati- } \\
\text { on- } \\
\text { based } \\
\text { learning }\end{array}$ & $\begin{array}{l}\text { Prepara- } \\
\text { tion and } \\
\text { follow-up }\end{array}$ \\
\hline An Investigation of the River Akerselva & $x$ & $x$ & & & $x$ & $x$ & & $x$ & & $x$ \\
\hline Birdwatching for Children & $x$ & & $x$ & $x$ & $x$ & $x$ & $x$ & & & \\
\hline $\begin{array}{l}\text { Children's interest gotten through } \\
\text { searching for plants }\end{array}$ & $x$ & $x$ & $x$ & & $x$ & & & & $x$ & \\
\hline Is the bog dangerous? & & $x$ & $x$ & $x$ & $x$ & $x$ & & $x$ & $x$ & \\
\hline Joy and learning in nature & & $x$ & $x$ & & $x$ & & & & $x$ & $x$ \\
\hline Junior Rangers-Kullaberg & & & $x$ & $x$ & $x$ & & $x$ & $x$ & & \\
\hline Karin the Cross Spider & $x$ & $x$ & $x$ & & $x$ & & $x$ & & & \\
\hline Life in the animal feces & & $x$ & $x$ & $x$ & $x$ & $x$ & & & & \\
\hline Looking for the Old-Growth Forest & & & $x$ & & $x$ & & & & $x$ & $x$ \\
\hline $\begin{array}{l}\text { Sedna-the ocean, the beach zone and the } \\
\text { boat }\end{array}$ & $x$ & $x$ & & & $x$ & & $x$ & & $x$ & \\
\hline The Animal Olympics & $x$ & & $x$ & $x$ & $x$ & & & & & \\
\hline The Grey Lady's fairytale forest & $x$ & $x$ & $x$ & $x$ & $x$ & $x$ & & & & \\
\hline $\begin{array}{l}\text { The shy and the beautiful, the bold and } \\
\text { the ugly }\end{array}$ & $x$ & $x$ & $x$ & & $x$ & $x$ & $x$ & $x$ & & \\
\hline Urban gardens in Fredericia harbor & $x$ & & & $x$ & $x$ & $x$ & $x$ & $x$ & & $x$ \\
\hline Vatnshellir-Visit the cave & & & $x$ & & $x$ & & & & $x$ & \\
\hline
\end{tabular}

All of the examples can be read in full in Appendix A, but we highlight a few examples that are especially useful as inspiration for how to implement the seven perspectives in practice: 


\subsection{Nature Interpreters as Facilitators}

The facilitators role is fulfilled by a nature interpreter who is conscious of his/her own role, knowledge and views, and who facilitates views, opinions and discussion with an aim to encourage participants to reflect. This involves participant-orientated work methods that organises and establishes frames for learning processes, and that clarifies views and stimulates openness for the understanding of the views of others.

Mobile Learning Environments is an example, where the aim is to create new opportunities for activities in nature, where pupils are engaged and curious, and where new technology is incorporated (mobile phones, tablets etc.). In this example, it is the nature interpreter's role to facilitate activities so that pupils are given a chance to be inquisitive, make decisions themselves and organise the exploration they are to do in nature - the framework is set up by the nature interpreter, but the content is set free. Quote from example:

“... Learning that takes the personal learning style of the learner into account is at the core of exploratory learning. This contributes to guiding the learners towards learning through channels that work for them, personally..."

The Lady Grey's Fairy-tale Forest is an example where storyline is used as a methodical framework for the activity, but where the participants themselves are co-writers of the story. The activities are built around the fairy-tale Thumbalina. Participants actively take part in the story, playing the animals that Thumbalina meets in the forest. The animals' welfare and mode of life is explored using the whole body and all of the senses. By the end of the activity, the participants themselves, based on their experience, continue to build on the story together, telling it to or dramatizing it for each other.

\subsection{The Immediate Experience}

Nature interpretation can be set up in different ways, for example through actions, activities, dialogue, storytelling, games, drama and so on, and this creates different experiences. The experience is the individual participant's own impression, which through communication can articulate and clarify terms and feelings, and thus turn the experience itself into experience the participant has accrued.

Ormen Orla og renoflex (Orla the Worm and renoflex) is an example of how daily life and waste management is made comprehensible for small 
children. In a playful and sensory manner, the nature interpreter poses several open questions to the children that lead them through a course where waste and decomposition is dealt with in a concrete manner. Quote:

“... I fetch a (playground) slide and attach it to a dumpster, so the children can

climb into it to collect a single item, and then slide out again ...."

Liv i lorten (Life in animal feces) is an example where subjects like ecology, bio-diversity and nature management is highlighted through activities based around exploring animal excrements in a field. By crossing boundaries and rendering the taboo accessible, attention to the circuitry of nature is in focus. The children have immediate and sensory experiences that can be used as memory aids, when complicated terms and ideas are to be understood. Quote from example:

"Fieldwork - it is absolutely essential that they are split into small groups, where they can conduct their own investigations..."

Karin Korsspindel (Karin the Cross Spider) is a course where a personification of the woodland animals, Karin the Cross Spider, is a recurring part of the activity. The children are led by Karin the Cross Spider through a series of challenges and explorations that give them an immediate understanding of the conditions of forest animal's lives.

Djurolympiaden (The Animal Olympics), like Karin Korsspindel, is an activity where children, by mimicking animal movements and qualities, are helped to understand animal behaviour and their role in nature.

\subsection{Reflection}

A visit provides opportunities for, and can stimulate reflection, which links to one's own life and can have an impact on one's own story. The nature interpreter as a facilitator steers reflection in a way that stimulates ownership. If nature interpretation includes the participant, so that he/she will reflect in a way that has a longterm effect, it is more likely to lead to the participant taking responsibility and involving themselves in the management of nature and environment.

The shy and the beautiful, the bold and the ugly is an example from Finland, where drama is used as a method to inspire reflection on the ways of animals and how they live. The participants are to convey this to each other. Observation, testing, presenting and subsequent reflection on animals' life conditions help create an understanding of animals' role in nature. 
Byhaver ved havnen i Fredericia (Urban gardens in Fredericia harbour) is a Danish example of gardens in mobile planter boxes. Through different methods of reflection, children's understanding of ideas relating to growing plants are explored. The plants' growth, light, nutrient and spatial needs are an immediate experience for children, and they are involved in the planning of these gardens.

Ormen Orla and Renoflex works by creating a scenography that leads to wonder in the individual child, so rather than asking concrete questions the experience itself encourages questions. Quote from example:

“...Instead of asking questions, my sets/scenography/objects, inclusion and contrasting of "local normality" and every day objects encourage curiosity and questions from the children..."

\subsection{Ownership}

The more one is involved in and work for any given change, process or better result, the higher the level of mental ownership. The feeling of ownership creates a greater incentive and inclination to work for, follow up on and take active part in something. The nature interpreter's use of methods that stimulate participants' thinking and visualisation of the future is one way to promote ownership and involvement.

Undersøkelse af Akerselva (An investigation of the River Akerselva) is a Norwegian example that takes its point of departure in a concrete environmental problem of the past pollution of the River Akerselva. Pupils are introduced to methods of analysing water, after which they conduct these tests themselves. The pupils are divided into smaller groups, and each member chooses their own area of responsibility and decide how to solve the task. In this way, a sense of ownership of the activity is instilled, and subsequently also a greater engagement with the river's environmental state-by adopting an area a greater bond is forged with the river. Quote from example:

“... Participants are split into groups where each member has an area of responsibility. Therefore, participants must themselves decide how to solve the task - through active involvement..."

"... The main principle of this project is that schools "adopt" a part of the Akerselva with all of the responsibilities that come with it. Schools will actively conduct investigations and keep up with the part of the river they adopt, so the relationship and interplay between the uneven parts of the ecosystem will be in focus..." 
Er mosen farlig (Is the bog dangerous?) creates a sense of ownership by triggering emotions. Quote from example:

“... Understanding of the relationship between people and nature is shown using the example of draining and pollution problems that are so great that the bogs are overgrowing. By taking part in clearing trees, they can see that even a school pupil like them can make a difference. And when they themselves have "done something" for the local bog it is easier for them to form an emotional attachment to it, creating a sense of ownership. And it's easier to bring the family out there with them..."

Junior Rangers is an international concept by EUROPARC Federation. Young people take part in nature care and mediation through summer jobs. They are introduced to local green associations that work with the protection of nature and cultural heritage among other things. Contacts are established through the work with these interest groups, and the whole idea is based on youth leading youth, and mutually encouraging active outdoor life and an increased understanding of nature.

\subsection{Comfort and Security}

It is important to consider how nature interpreters can develop and use relationship-building activities that promote a sense of comfort and security. This involves activities aimed at the individual or at the entire group, also in relation to the inner dynamics of the group.

Friluftscirkus (Outdoor Circus) is a Swedish initiative where young people, through outdoor life and crossing "pathless terrain," have experiences that are close to nature and get a chance to gain better insight into themselves and their relationship to other young people and the natural areas they are in. Traditional camping is combined with circus activities, which requires cooperating, taking responsibility for each other and organisation. Talk and dialogue in smaller groups creates comfort and security, and the activities do not force the young people to compete, but allows them to do what they can to the best of their abilities. Security and trust within the group is a necessity for everyone to have a good experience, and this is achieved by working together.

Naturtypekartleggning i sjøen (Mapping ocean habitat types) is an underwater activity where all participants are given a chance to try snorkelling in the ocean. Training for snorkelling activities, combined with field investigations of shore habitats, challenges and instils a sense of control of the body. The feeling of security, in particular, is a necessity 
for the experience to be a success. A sense of security is generated gradually through snorkelling activities.

In Ormen Orla og Renoflex it is the familiarity of the known (the slippyslide) that provides the comfort and security necessary to slide into the unknown (a large dumpster) and in Byhaver ved havnen the nature interpreter is very conscious of greeting all of the children personally, to create comfort and a connection between him/her and the children.

\subsection{Location-based Learning}

The outcome and yield of teaching very much depends on whether or not an event with a nature interpreter is integrated into the participant's daily learning or everyday life, ensuring that the visit and activities function in the context of a coherent learning course. This takes preparation for the visit and follow-up work.

It makes sense, for example, for a class that participates in nature interpretation activities to visit the same nature interpreter several times as a part of a planned learning course. Here, teachers play a vital role. How can a nature interpreter best help teachers so that they feel comfortable and prepared for the event, and so that their teaching is integrated before, during and after the visit?

The specific site chosen for nature interpretation activities makes for opportunities. Every place has its own history, culture, stories and happenings. This provides an opportunity for participants to get special knowledge of and feelings connected to the place they are in. For example the development of feelings for and identity in relation to their own local or natural area. Methods that contribute to creating a relationship and interest to the place can help increase interest in engaging with nature and environmental questions, to preserve a protected nature site or develop the peri-urban nature environment.

Er mosen farlig is built around walking in a bog, which is an unfamiliar place to be in for most children and young people. During the walk, stories that depict superstition, myths and old cultural history are told. Using the bog as a natural basis for existence is exemplified by peat gathering. This example's activities also include active nature recovery, where children are involved in the felling of trees so the bog doesn't overgrow, but is preserved in its natural state. This active act creates a broader understanding for nature recovery and preservation.

Sedna - Havet, strandzonen og båden (Sedna - the ocean, the beach zone and the boat). Learning to be at sea on nature's terms is vital. This 
example shows how knowledge of the sea, boats and cultural history connected to sailing and fishing can be used in pedagogical work with young boys, in particular, that are struggling in the traditional school system. The activity strengthens cultural understanding and aids Faroese identity. The Faroe Islands have a strong seafaring tradition and it is essential that one knows the tough conditions of living in an archipelago in the middle of the North Atlantic.

Vatnshellir (Visit the cave) is teaching that takes place in the special setting of a cave. Darkness, the unique geology and special location is used to invoke and incorporate the participants' senses and ability to express themselves artistically. Poetry writing, singing and painting, as well as the darkness and quiet in the cave, are used as sensory stimuli to highlight the cave as a unique biotope.

\subsection{Preparation and Follow-up}

The outcome and yield of teaching very much depends on whether or not an event with a nature interpreter is integrated into the participants' daily learning or everyday life, ensuring that the visit and activities function in the context of a coherent learning course. This takes preparation for the visit and follow-up work. Several of the examples highlight possibilities for improving activities and following-up on the experience and gathered results after the event:

Looking for old-growth forest is a Finnish example of how an investigation of forest ecology is integrated in school's national curriculum. The nature interpreter gives the school assignments to work on in preparation for the visit. This is a good example of a nature interpreter's planning not just being limited to a single visit, but incorporating forest activity in a long-term course.

Byhaver på havnen sees nature interpreters visiting schools prior to the activity, helping to plan the planter boxes. The classes decide what they are going to plant in the boxes. They work closely with their teacher, and a central part of the work is deciding who does what. Quote from example:

“...It's important to clarify everyone's expectations with the teacher joining the class on the trip. Who does what? He/she should be prepared for the event...."

“....It is even more important that the adult knows that the visit isn't just a single visit, but 6-8 visits over spring and autumn...” 
At følge storgærdet (Following the village wall) is an example from the Faroe Islands where children explore the town wall. The trip is followed up on with questions and assignments to be completed at home with their parents. In this way, a connection between school and home is established, and parents can help contribute with their own knowledge. Quote from example:

“...Pupils answer questions on facts about the stream and the local area with help from their parents at home. The questions can be phrased as claims that can encourage discussion with the parents..."

Figure 3.1

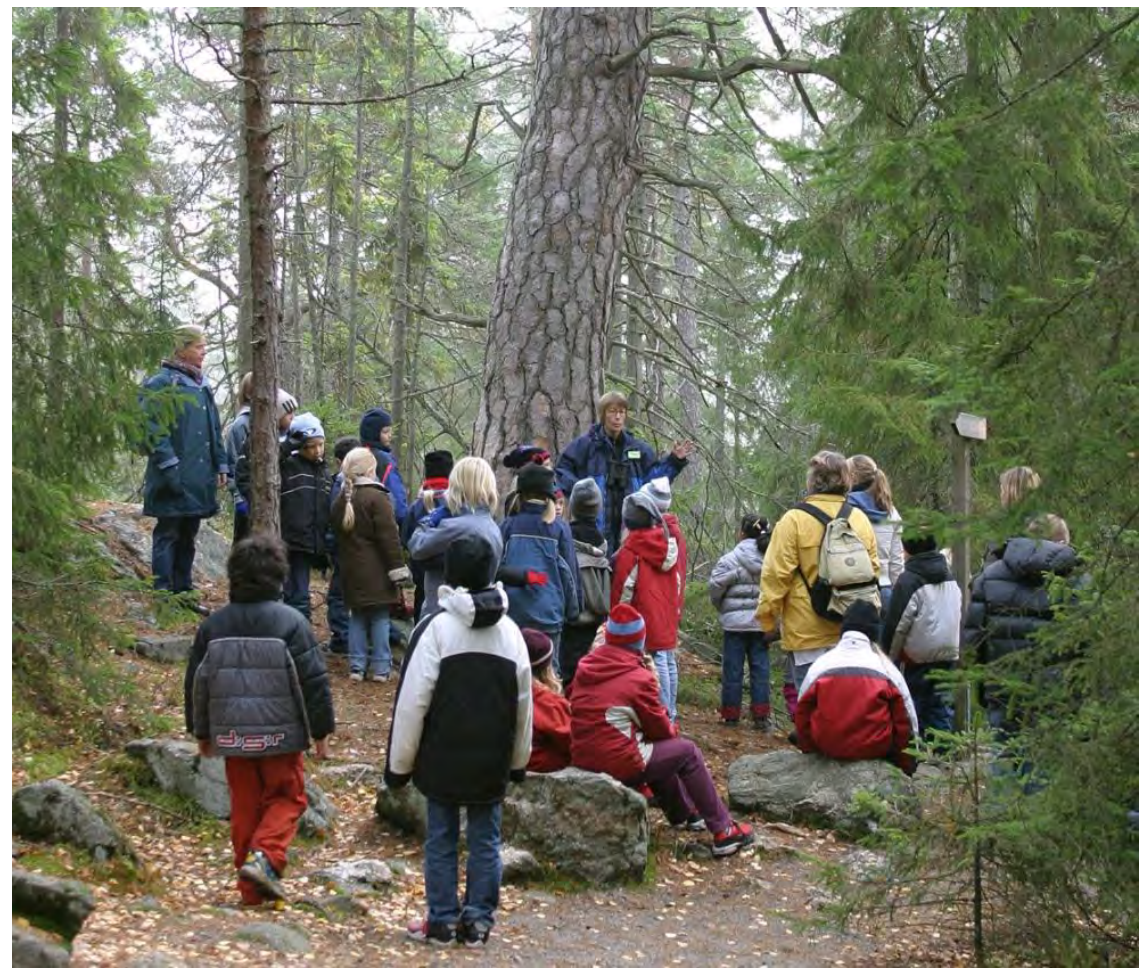

Photographer: Pella Thiel. 



\section{Make a Lasting Impact with Your Nature Interpretation - Enhance the Feeling of Ownership}

By Søren Breiting, Department of Education - Curriculum Research, University of Aarhus, Denmark

We share a lot of information when we have visitors to our place or on a tour. But how much is retained them when they leave us? And how committed will visitors remain in relation to the questions we tried to promote? A part of a fruitful strategy is having knowledge of mechanisms that can enhance a feeling of ownership to the questions we address during a visit. This isn't rocket science, but is often neglected in many initiatives and daily activities.

\subsection{Getting a Feeling of Ownership of Things}

We are all familiar with feelings of ownership. We might buy a bike and, of course, feel that we own it. If someone steels it we become very angry and sad because it was my bike! When we've just bought it we are happy to show it to others - see, my new bike - it has this or that advantage and qualities - isn't it nice? The more we have had to strive to cover the cost of the bike, the more likely we are to be happy with it. The longer we have spent looking for the right bike, the more likely we are to be particularly keen on it.

But we can also develop a feeling of ownership of things we don't own. 


\subsection{Getting a Feeling of Ownership of an Idea and Something We Don't Own}

If you give a good friend advice on how to cook a special dish for a party and your friend follows your advice, you will develop a feeling of ownership of how well your friend is following your advice and how well it turned out.

After the party, you will probably ask your friend about the party and how the dish was received. If your friend tells you that it was a total disaster, as the friend couldn't cook it properly or the guests didn't seem to like the dish, you will feel very sorry. You feel partly responsible even if it wasn't your fault. If the dish was a big success, you will feel quite proud and say to yourself my advice-just as I thought! So the positive feedback from your friend will enhance your feeling of ownership in terms of your involvement in the success of the party.

Every time we get the chance to have an influence, we have a potential to develop feelings of ownership of the situation at hand.

\subsection{As a Nature Interpreter You Have Full Ownership - But What About Your Guests?}

When you plan a visit to your place for a group, you develop a full feeling of ownership of the program and the activities. You might have requests and ideas from the teacher following the class or from others, but ultimately you will have made the decisions for your planning and during the concrete program. All in all, you are the "protagonist" during the visit, and you do your best with what you know and feel will work well.

Your visitors might be very happy with the whole program - it was a lot of fun and very interesting, they might tell you, and that's nice - actually, this will stimulate your feeling of ownership of the visit and the program.

For your visitors to develop a feeling of ownership themselves, they need to feel that they have been an influential part of the programme. If they tell you, as they leave, that they came up with some good ideas they will try to use at home, you will know that they developed some feeling of ownership related to the things you focused on during their visit. 


\subsection{The outcome for your visitors is not only about what they remember}

When we guide a group, we pass on quite a lot of information and - honestly - we know that a lot is lost among the participants before they leave. In any case, the exact information might have an important role in the situation for the visitor to understand something or to do something, so we cannot measure the outcome of a visit afterwards by measuring the retention of what was told and experienced.

Optimising the preparation for the visit and, even more importantly, optimising the elaboration on the experience of the visit back at the school afterwards, are some of the most important elements of the optimal learning experience of a visit. This deserves an article of its own, but here we will continue with factors that enhance the feeling of ownership to ideas, questions and issues during the visit.

\subsection{Ownership Relating to a Conservation Issue}

Conservation is a priority for many guides in national parks. Often this is exactly the argument for funding the staff of a visitor centre and the nature guides there. Different kinds of persuasion are often used as strategies in the communication with visitors. The guide will come with as many good arguments for the conservation case to persuade the visitors to support this idea. This is actually a very fair way of giving information to the visitors at such a place, and it is also well-received and expected in general.

If the guide is very successful with this strategy, visitors might engage with concrete conservation problems, but often this will be a rather superficial engagement that will be overruled by other interests and demands after the visit.

Other approaches could be considered to enhance the feeling of ownership in a more profound way. Before we elaborate on these, let us take a look at what research on mechanisms that support the development of feelings of ownership says.

\subsection{Mechanisms that Develop Feelings of Ownership}

Here, we are focussing on feelings of ownership of ideas etc. This kind of ownership feeling is also called mental ownership to distinguish it from the feeling of ownership of things you own - legal ownership. 
A number of aspects will enhance the mental ownership of visitors, during their visits, of your ideas and the whole set-up at the visitor place; see the list in Box 1.

\section{Box 1}

List of aspects to take into account to support the development of mental ownership

If all involved participate in the goal setting or strategy formulation, etc.

If all concerned are regarded as "equal" partners in the process.

If all have a direct interest in the changes.

If those involved give input to the process.

If they can find their "fingerprint" in the final outcome.

If they receive some form of recognition for their contribution to the process.

If they feel they really understand the issue.

(After Breiting, Imene \& Macfarlane: Life Science Project Midterm Review. 1997, supplemented with Breiting 2008).

The more you show respect for the visitors, even if they are small children, the better. Even younger children "grow" when they feel their ideas and concerns are taken seriously.

If you have any questions related to the planning process, you can also involve the pupils in such decisions: Should we visit the $x x x$ first (and why), or should we start with yyy? The point is that such decisions might be a little awkward for you, but they help visitors feel that they are respected and are taking part in the decision-making.

It can be difficult to take all participants' ideas into account. A possible route to take is to have everyone writing down some ideas on a small piece of paper, to pass them around before you collect them and to try to make the best use of all of them.

When you ask the visitors questions, don't ask questions related to their knowledge (might be OK in some cases, but such questions will not enhance the feeling of ownership).

Quiz them on what they like, feel is fair, feel is interesting, etc. as this will engage them on a personal level. Let them explain their points of view and give them some social recognition for their ideas and points, even if you might not agree.

In light of education for sustainable development, a key element is to highlight alternatives for future development. I am sure you have your own ideas of what is a better path of development, but it is more important to stimulate your visitors to emphasise their ideas of alternative 
"good" ways of development. Let them put their ideas forward and let others participate in the discussion. The most important thing is that as many of the group as possible start reflecting on the questions at hand.

Make sure that the participants actually understand the whole thing. This isn't easy with a difficult idea like "sustainable development." You will have to live with some variation in the understanding of the concept or idea, but either way you can do something to facilitate reflections related to the concept, and create a fruitful atmosphere for "stupid questions."

With "stupid questions," I mean questions that the participants are feeling quite embarrassed to ask because they feel that they should know the answer already. Such questions are often of a more basic nature, and that means that a lot of other perspectives of understanding are based on the understanding of the "stupid question." Questions are a good way to establish a dialogue with the visitors, and you can emphasize that questions are very welcome, and that if "there is something you don't fully understand, I am sure others feel the same!"

When you later refer to questions asked as valuable questions, or whatever superlatives you might find relevant, your "social recognition' will enhance the feeling of ownership of the question (and to your explanation) among the group. You could even enhance this, showing your appreciation by placing a hand on the shoulder of a boy who asked a "stupid question" and saying something like: "When this young man asked about, it gave us a fine opportunity to talk about important aspects of vvvv."

When the group is engaged with practical activities, try to highlight the performance of some pupils that you might feel aren't the "top dogs" in the class, and you will see them grow and engage with the activities. Actually such small praises might change their behaviour and feelings of self-confidence back in the classroom, and provide a strong feeling of ownership of this specific positive situation during the visit.

\subsection{How to Develop Understanding and Ownership of Sustainable Development}

As mentioned previously, the idea or concept of sustainable development is a very abstract and difficult concept to grasp fully. To put it briefly, sustainable development is an idea that satisfies the present generations' needs, and makes sure to do it in such a way that coming generations will have decent living conditions, equal to those of the present. It is, however, obvious that this isn't happening at the moment. 
Billions of people in the world are living under very poor conditions, and many children go hungry much too often. In our part of the world, many people are suffering because of our modern way of life.

When we look at the consequences for future generations, we can easily identify aspects of the present development that are against the interest of coming generations. Our pollution, depletion of resources, and general short-term management of our living conditions undermine the options of our grandchildren.

Actually it is much easier to identify aspects of development that cannot go on, compared to aspects that we can feel sure are sustainable and can go on "forever."

As an alternative to try to explain and discuss these matters with the visitors, you can organize an activity that helps the visitors to develop their own ideas of sustainable development. See Box 2 for details.

\section{Box 2}

What are the most sustainable aspects of development according to your own ideas of sustainable development?

This activity is based on group work where the group decides what aspect of development they believe to be best, seen through the eyes of people living today and "their grandchild." You can make your own variation, but here are some ideas. It might be best to put them on a continuum to underline that such aspects will never be absolute choices.

- People use as much energy as they want. $\leftrightarrow$ People cannot use as much energy as they want.

- Society is using the cheapest source of energy as available. $\leftrightarrow$ Society is taking not only taking price into account, but also the consequences for the environment when choosing sources of energy.

- It is the smartest people in society that control most of the resources. $\leftrightarrow$ Society has mechanisms that counteract smart people controlling most of the resources.

- Only the richest people can afford to eat meat. $\leftarrow$ Most people can afford to eat meat.

- Higher education will only be available to families who can afford to pay for their children's studies. $\leftrightarrow$ Higher education is available to anyone with the necessary

- Medical treatment is for those who can pay for it. $\longleftrightarrow$ Hospitals and other medical treatment are available to those who need it.

- People in China and India should not have the same living standard as we have in the west (they are too many). $\leftrightarrow$ Everyone should have the chance to have the same standard of living as us. 
- Girls and boys are very different by nature, so girls don't need as much education as boys. $\leftrightarrow$ Girls and boys should have equal opportunities for education.

- It is more important that boys learn to read than girls. $\leftrightarrow$ It is equally important that girls and boys go to school and learn to read and many other things.

- Clean drinking water can be bought bottled-it is too expensive to care for water in nature. $\leftrightarrow$ It is important to keep water in nature clean for drinking water.

- If we have no use for animal and plant species, they might as well die out. $\leftarrow$ We shouldn't make any species extinct because we cannot bring them back.

- If we cannot agree on a certain problem related to the use of natural resources, we shouldn't bother with regulating their use. $\leftrightarrow$ The use of natural resources should be regulated and long-term concerns should have a high priority.

- We should put ourselves in the shoes of our grandchildren, when we plan for the present generation. $\leftrightarrow$ We cannot take the interests of our grandchildren into account: they will have to take care of their own interests when the time comes.

Such a (so-called) inductive approach to develop understanding is also helpful for the development of mental ownership of the idea, because the process involves a number of "smaller" decisions. The selection of aspects and the way they are formulated has to be adjusted to suit the age of the participants.

Some of these aspects can be illustrated and used even without text, and that will be a helpful visualisation, which supports the ideas and associations of the participants. An example could an image split into two: One could show the insides of a classroom with only boys inside it, and through the window, a view of a field outside where girls are cultivating the field. The other side shows a version of the classroom with a mixture of both girls and boys inside.

The point is that these questions will stimulate discussion and reflection among the participants, and in that way prepare them for the overall idea of sustainable development. It might be a good activity for a class to do with their teacher prior to a visit.

\subsection{Time is Always the Limit}

During a visit to a place, time will always place an inconvenient cap on the duration of the program we can plan and be sure to complete. This is, of course, always the basic didactic question - what will be the best use of the available time? We have to make sure that the class and the teacher 
get their aims for the visit fulfilled. Expectations are related to those of the guide and the nature area will "deliver" so the visitors learn something to bring back home to school, together with a feeling that it has been a good experience.

Some of the mechanisms might make the visit less "efficient," seen from the perspective of communication of knowledge. On the other hand, the long-term outcome of the visit will depend rather a lot on how well the visit is able to generate a feeling of ownership of relevant issues. For the long-term outcome of the visit, the teacher's focus after the visit on the content and activities is the most important enhancement of what the pupils learn.

\section{Figure 4.1}

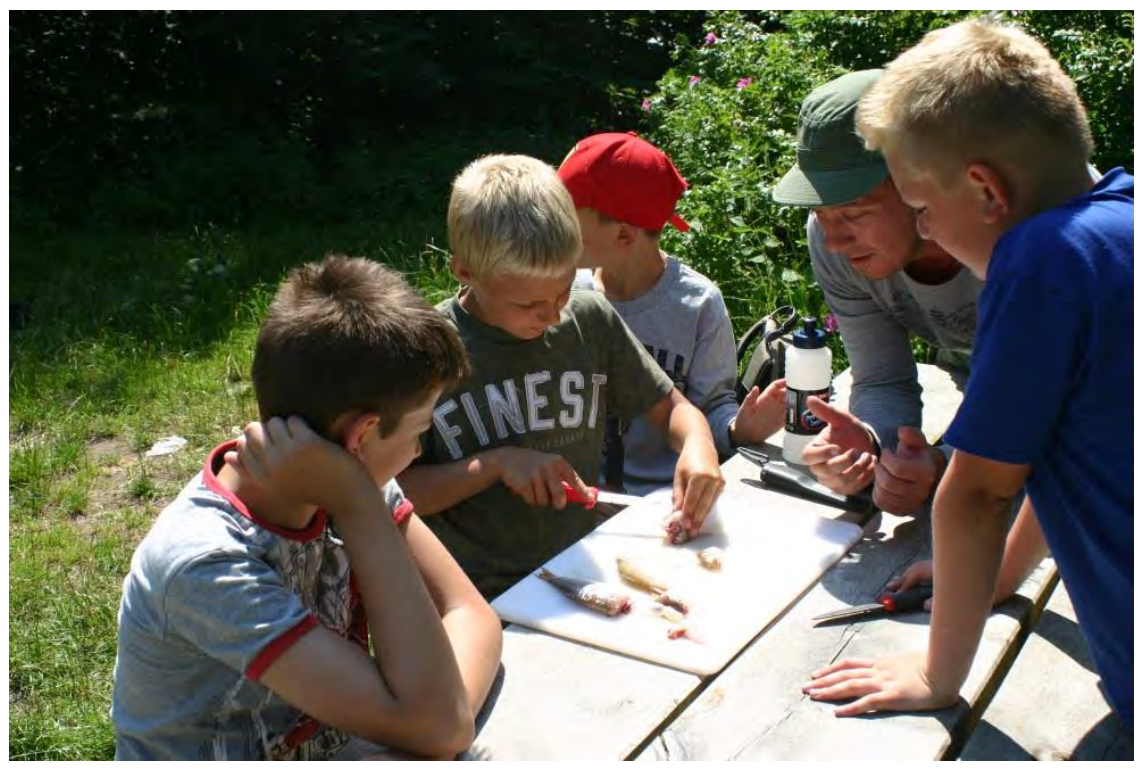

Photographer: Mette Aaskov Knudsen. 


\subsection{Literature}

Andersen, A. M., Breiting, S., J. B. Hansen, K. Nielsen (1998): Naturoplevelser og naturskoleundervisning. Danmarks Lærerhøjskole og Friluftsrådet. 128 s. Brænderup.

Breiting, S. (1991). Nature Investigations as Blind Alleys in Environmental Education. Environmental Education \& Health Education. International Contributions 1990. Proceedings from The Research Centre for Environmental and Health Education. København, Danmarks Lærerhøjskole. 15: 29-43.

Breiting, S. (2008). Mental Ownership and Participation for innovation in Environmental Education and Education for Sustainable Development. Pp 159-180 in: A. Reid, B. Bruun Jensen, J. Nikel and V, Simovska. Mental Ownership and Participation for Innovation in Environmental Education and Education for Sustainable Development.

Breiting, S. \& D. Ruge. (2006): Skolers besøg på økologiske gårde. Århus: Økologisk Landsforening. http://www.okologiiskolen.dk/pictures_org/skolebesog_web_2007.pdf

Breiting, S. \& D. Ruge. (2007): Inspirationer til ekskursioner. Århus: Økologisk Landsforening. http://okologiiskolen.dk/pictures_org/InspirationerEkskursioner.pdf

Breiting, S. og K. Schnack. (2009): Uddannelse for Bæredygtig Udvikling i danske skoler: Erfaringer fra de første TUBU-skoler i Tiåret for UBU. Forskningsprogram for Miljø- og Sundhedspædagogik, DPU-Danmarks Pædagogiske Universitetsskole, Aarhus Universitet. København. Download from http://tubu.dk

Breiting S. \& P. Wickenberg (2010). The progressive development of environmental education in Sweden and Denmark. Environmental Education Research, vol. 16, $\mathrm{n}^{\circ}$ 1, February, p. 9-37.

Wistoft, K., C. R. Otte, M. Stovgaard og S. Breiting (2011): Haver til Maver-Et studie af engagement, skolehaver og naturformidling. Institut for Uddannelse og Pædagogik (DPU), Århus Universitet, København. http://www.udeskole.dk/media/haver-tilmaver-2011.pdf 



\section{The Demanding Role of Nature Interpretation Sites}

By Lili-Ann Wolff, Generel Education, Åbo Academy University, Finland

This article discusses how the mission of sustainability ${ }^{2}$ can be fulfilled at visitor centres, nature schools and in other nature interpretation contexts. The discussion is based on two questions: Firstly, what is the role of nature interpretation sites today? Secondly, is it unrealistic to try to promote as tremendous a goal as sustainability on these sites? It may seem impossible to change the world in a place where visitors often only stay for a few hours, but maybe there are other ways to work with complicated issues like sustainability. I will propose a strategy for the development of nature interpretation sites based on four fundamental practices that can be chosen simultaneously or separately. These fundamental practices are nature as a state of mind, teacher training, collaboration, and practice architecture. In the paragraph below, I will explain what these four topics mean and why I find reflecting on them to be worthwhile. The explanation is based on both experience and educational research.

\subsection{The Point of Departure}

Outdoor education at its best engages the whole person (without any distinction between body and mind), builds on collaboration and joint activities, is practically performed, contains new knowledge, and deals with a topic that is relevant in everyday life. But if we want nature activities to have long-term effects like sustainability, one day still might not be enough, as there are so many influences in society that encourage the opposite (the unsustainable).

${ }^{2}$ There is a strong disagreement on what this complicated and even paradox concept stands for, since development and sustainability are difficult to combine. Of that reason, I prefer to talk about merely "sustainability." 
Although education may affect attitudes and values, it does not instantly bring about a change in behaviour. The desire to act does not necessarily instil the will to do so, because the will is steered by so many conflicting desires. Of all such pressures, the desire to adhere to social norms - to avoid attention and to fit in - is very strong. A Finnish study has shown that even if young people are concerned about the environment, are positively inclined towards environmental issues, and even say that they want to take action, they do not necessarily do so. About half of the participants in Hannele Cantell's and Riitta Larna's large survey were interested in contributing to environmental protection and sustainability, but only five percent actually did. Lack of knowledge was not the problem; a gap existed between intention and action. They knew how best to act, and even wanted to, but still they did not. How can we meet this challenge? Since forcing or manipulating others to act is not a good option, I find it crucial to start a discussion about what the other options might be. Is it possible, by any means, to encourage other people to start acting responsibly towards the environment? If it is, what then is the role of nature interpreters and nature interpretation sites in this endeavour?

\subsection{The Role of Nature Interpretation Sites in the Nordic Arena}

Nature interpreters are people that work as a bridge between the natural world and their audience, and thus help people to cross the line and become more familiar with the rest of nature. From the very beginning, Nordic nature school teachers have played a slightly similar role to nature interpreters because, similarly to nature interpretation, nature school education has had a strong focus on nature activities. Like interpreters, nature school teachers' role has been to encourage a feeling for and knowledge about nature. Many Nordic nature schools have also offered teacher training and participated in projects together with schools and other interest groups, including local and national governmental organisations, in the development of environmental education in their respective countries. The publication Naturskoler i Norden (Nordic nature schools) from 1996 mentions the role of nature schools as innovation and resource centres, and forerunners in the development of environmental education methods. In a similar fashion to the way it was done in the mid-1990s, I identify the same basic tasks of nature schools and other nature interpretation sites today: (1) to inspire students to care about nature by offering engaging experiences outdoors, (2) to con- 
tinuously arrange teacher training, (3) to participate in long-term projects and other kinds of collaboration with diverse groups to reach more complex goals, and last but not least (4) to function as innovation centres, not only for teaching methods, as suggested in 1996, but in the entire sustainability process for school communities and others in their neighbourhood. In the following section, I will discuss how each of these four tasks can be developed further.

\subsubsection{Nature Experiences}

In her recent doctoral thesis Pia Sjöblom denotes that secondary school students are detached from nature, and that schools have not succeeded in promoting student interest in nature. Sjöblom calls for more outdoor education during school days, and this is also what Negev and others request in a large Israeli study. Many empirical studies in environmental education confirm that there is no significant correlation between environmental knowledge and environmental behaviour. However, according to the Israeli study, there is a correlation between students' opportunities to enjoy nature with adults, and their environmental behaviour and respect for the natural world.

If we take the last mentioned study seriously, the most important tool for teachers and nature interpreters is their attitude towards nature. This possibility is worth reflecting on when planning short trips and one-day programmes. But what does it mean? When it comes to the introduction of new places and phenomena in nature, guidance or movement can neither be open or closed. An open approach means that the activity takes place without any planned course, while a closed approach is carefully planned with few possibilities for improvisation or change of course. Since the open approach builds on the actual state of nature and human reaction, it is an approach open to surprises. Therefore, a well-organised and planned-in-detail approach (closed) may sometimes be the better choice, especially for an amateur interpreter, though there is a risk then that the nature interpreter misses unique chances to engage students in current nature phenomena. The choice between an open and a closed approach may become a choice between supporting rational understanding (including naming concrete things in nature) and emotional engagement, but experienced interpreters can train themselves to generate both understanding and emotional experiences simultaneously. Another distinction to be aware of is the personal view of nature. Is it an anthropocentric (centred around human beings) or a biocentric (centred around nature) view? The view will, without a doubt, influence the education. 
When teaching about topics in relation to nature, environment or sustainability, the outcome depends on one's own view of the world; aside from ethics, these also include spatial and temporal aspects. Nobody can shake off the dispositions, values, and attitudes bequeathed by one's background and framework. Nature interpretation always reflects the teacher's or the interpreter's philosophical and theoretical position that, in turn, depends on assumptions about knowledge, human beings and the world. Various philosophical assumptions thus hide in instruction and, therefore, interpreters need to be aware of their own relation to other persons, nature and environment, diverse cultures, economics, politics, and so on. As these relations vary considerably, a closer investigation actually shows that there are a plentitude of approaches to environmental matters and sustainability in education. Every activity depends on a choice: something is included and something else excluded. The individual aims of lessons and educational programmes are diverse: some are partly obvious and others tacit. Due to intricate value conflicts, tremendous gaps between aims and actions exist both on the individual level, in society and in the field of education.

Likewise, students' views may vary and thus, for example, a lake may have many meanings depending on how both the teacher/interpreter and the students think about it. These different views are good starting points for discussion, and answers may well remain open. Examples of points of view are:

- Biological, as an ecosystem, biodiversity, species.

- As an environmental problem.

- Aesthetic, as a piece of art.

- Magical, as a tale.

- Pragmatic, as a place for fishing, swimming, hunting, etc.

- Cultural historical.

- As a holy place, as a piece of the Creation.

- Ethical, with or without an intrinsic value.

A good nature interpreter might not choose particular views, but trigger participants to reflect on and discuss diverse alternatives. When a interpreter focuses on the moment (the here and now), she or he is attentive towards both humans and other parts of nature, dares to step aside, and makes room for many other perspectives than her or his own. The attentive nature interpreter does not have any simple, straightforward answers, but the activities and the instruction builds on joy, imagination and playfulness in addition to responsibility, respect and togetherness, 
in combination with knowledge. But knowledge might not be what a person wants first in an unfamiliar environment.

In Michael Bonnett's view, education for sustainability has to change focus from policy to a state of mind, involving an idea of human being's relationship to the rest of nature, where nature is an integral element of authentic human awareness. Sustainability itself then takes on new meaning and is no longer a mode simply for human utilization of nature; rather, nature is something living for its own sake and needs "to let be." Education in line with Bonnett's thoughts concentrates on ethics as practical undertaking (morality), but it is based on different metaphysics. It is an ethics of receptive response to the natural world instead of rules; and, in opposition to a strongly rational approach, it focuses on a more intimate, intuitive and sensuous encounter with nature. One of the most important tasks of a nature interpreter is to try to encourage a genuine interest for nature as the dwelling place for every human being, and an element that resides inside every one of us.

\subsubsection{Teacher training}

When participating in sustainable activities, the students maylearn to take the first stumbling steps on the "rocky road" towards a more sustainable life on earth. Yet, lack of encouragement, or even discouragement, may cause motivated persons to fail to act on their commitment to the environment. Therefore, it is necessary to provide children and young people with adult support and companionship during the processes in which they learn to see themselves as social actors and users of power, and develop their own strategies of action. A nature interpreter or nature school teacher can be such a person, but school teachers spend much more time with students. By training school teachers in diverse contexts, both outdoors and indoors, teaching them how to involve their students in nature and sustainability matters more, students are continuously reached. Therefore, there is a need for teacher training that deals with how to relate to sustainability issues as reflective practitioners and learning facilitators. When dealing with sustainability, the way teachers undertake the teaching task can be pictured in three ways:

1. The teacher imagines an ideal society and tries to form ideal persons to suit those conditions. (Education as a mission-this method is used to achieve visionary approaches, especially religious and political aims, but it is also common in environmental education). 
2. The teacher bases education on ideas about what kind of persons she or he thinks contemporary society needs. (Education as transmissiondifficult in a fast-changing world).

3. The teacher train students to be autonomous, so that they can form a society that they find best. based on their own understanding and from their own perceptive. (Education as transformation).

I have led many teacher training courses and seen the advantage of giving school teachers support in the form of training, which encourages them to start developing their own environmental education in the context and surroundings of their own school. Awareness of their own thoughts and values influences teachers' teaching, as well as their commitment. If teachers are not committed, students are hardly going to be either.

\subsubsection{Long-term Projects and Collaboration}

As a manager of a few long-term projects, I have realised that commitment takes times and is jointly established, and might need the involvement of entire staff groups from schools and other institutions. For people to engage in sustainability, it needs to become a process that enables them to reflect on their own role in this process, and how their lives relate to other forms of life, institutions and social systems. Society and individuals steadily transform when individuals participate in social processes. Social conditions and individuals are shaped in a joint social process of participation, collaboration and communication.

An educator also needs to offer possibilities for students to reject the idea of sustainability. Through discussion, students have a chance to reflect on whether they are interested in being involved in this process or not. With partnership and participation in discussion, the sustainability process becomes a joint activity where visioning, planning, activities and evaluation continually follow each other in a steadily transforming process that engages a diversity of stakeholders in democratic processes, and enables their understanding of multiple views. 


\subsubsection{Practice Architecture}

Even if schools are important places in young people's lives, they also learn in many other places. From an educational point of view it is important to reflect on how democratic and sustainable these places are, since experiencing democracy and sustainable manners can help these become ways of life, and not just diffuse prospects. Gert Biesta puts a special emphasis on the difference between democracy as an aim and a process, but the same counts for sustainability.

Even if it is agreed that nature schools complement schools in their environmental education, my opinion is that all kinds of visitor centres and interpretation activities that have sustainability as an important aim, need to take this assignment seriously and conduct the sustainability process in their daily work and life. This means that sustainability becomes a duty even more serious than what is stipulated in school curriculums, and what teachers may actually want for their students at nature interpretation sites. Sustainability and student wellbeing need to become the beacon of the sites, so the persons managing and upholding them dare to lead the way on the road towards sustainability, and fearlessly resist unsustainable supplies and methods that belong to lifestyles, which uphold global inequality and an unhealthy planet. The site shall not be a place for preaching, but a place for accomplishment. Instruction has never been and never will be neutral, even if it is of no use to try to "save others" from environmental destruction. Sustainability has to be everyone's own choice, but the people who are workers in this process need to act as role models. Stephen Kemmis and Rebecka Mutton call a site that lives (does) and communicates (says) the values it wants to promote practice architecture. In such a site sustainability is a noticeable commitment.

\subsection{Conclusion}

The last decade has initiated an obvious change in research methods in environmental education, perhaps thanks to increased political emphasis on environmental issues. The focus has moved from normative prospects to promoting common accomplishments. A growing number of researchers in the field of environmental education are interested in improving students' joint involvement and participation in authentic environmental activities and critical discourses, and in how to encourage people to take responsibility for environmental issues that directly affect their own lives. Other new interests are bridge-building between various social groups and focusing on transformative learning. 
In my own research, I have distinguished that sustainability challenges three human dimensions: (1) the sphere of the self, where people develop their own identities; (2) the social sphere, where an individual interacts with others in all kinds of joint activities (politics, religion, education, arts, sports, etc.), and (3) the sphere of the natural world (the interaction between human beings and the rest of nature). Environmental problems are caused by what takes place on individual, social, and "natural" levels. Human beings shape their relation to nature through their view of themselves, of others, and of the entire planet. These ethical dimensions, however, are not separate or hierarchical: all three interact. Non-sustainable life has not come about all of a sudden and will not be overcome without effort. Commitments to changed procedures are initiated through communication and joint activity, enabling shaping and reshaping of both individual and social action strategies. Nature interpretation sites can develop into model sites, where the sustainable mission is clearly performed, and provide possibilities for visitors to participate in a more sustainable life than they are used to from home, school and other places they are familiar with (real as well as cyber spaces). An important way to perform the interpretation task is also to visit schools and others in the informal or non-formal educational arena, and thereby discuss with various stakeholders what sustainability might be - not what it is - since sustainability has to be created jointly. How an interpretation site can best move towards sustainability, through a democratic process with the resources available, requires reflection and discussion. In this article, I have tried to bring possible options to the foreground, inspire discussion, and trigger your thoughts on this complicated subject, in the hope that you will proceed beyond what I have initiated. 
Figure 5.1

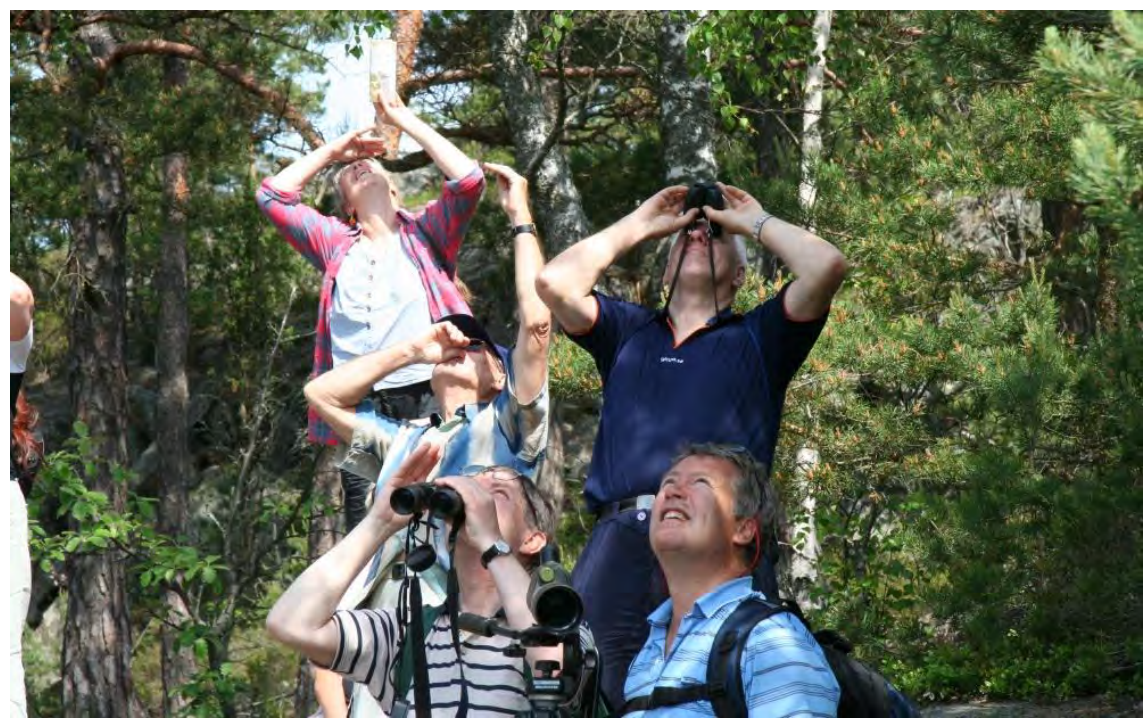

Photographer: Per Sonnvik.

\subsection{Literature}

Biesta, G. (2003). Demokrati: Ett problem för utbildning eller ett utbildningsproblem? Utbildning \& Demokrati, 12(1), 59-80.

Bonnett, M. (2006) Education for sustainability as a frame of mind. Environmental Education Research, 12(3-4), 265-276.

Bonnett, M. (2009). Systemic wisdom, the "selving" of nature, and knowledge transformation: Education for the "Greater Whole". Studies in Philosophy \& Education, 28(1), 39-49.

Cantell, H. \& Larna, R. (2006). Ympäristövatullisuus nuorten sanoissa ja teoissa (Environmental responsibility in young people's words and deeds). Helsinki: Helsingin kaupunki, Opetusvirasto.

Engaging people in sustainability. (2004). Gland: IUCN, Commission on education and Communication.

Jickling B. \& Wals, A. E. J. (2008). Globalization and environmental education: Looking beyond sustainable development. Journal of curriculum studies, 40(1), 1-21.

Kemmis, S. \& Mutton, R. (2012). Education for sustainability (Efs): Practice and practice architectures. Environmental Education Research, 18(2), 187-207.

Koskinen, S. (2010). Lapset ja nuoret ympäristökansalaisina: Ympäristökasvatuksen näkökulma osallistumiseen (Children and young people as environmental citizens: Participation from an environmental educational view). Helsinki: Nuorisotutkimusseura.

Koskinen, S. \& Paloniemi, R. (2009). Social learning processes of environmental policy. In J. Meijer \& A. der Berg (Eds.), Handbook of environmental policy (pp. 293-308. New York: Nova Science. 
Lange, E. \& Chubb, A. (2009, December). Critical environmental adult education in Canada: Student environmental activism. New Directions for Adult \& Continuing Education, 124, 61-72.

Miranda, B., Castells, M., Oliver, M. F. \& Cabral, S. (2004). Questionnaire results. In B. Miranda, F. Alexandre \& M. Ferreira (Eds.), Sustainable development and intercultural sensitivity: New approaches for a better world (pp. 89-128). Lisbon: Universidade Aberta.

Naturskoler i Norden. Nord 1996:8. Kopenhagen: Nordisk Ministerråd.

Negev, M., Sagy, G., Garb, Y., Salzberg, A. \& Tal, A. (2008). Evaluating the environmental literacy of Israeli elementary and high school students. The Journal of Environmental Education, 39(2), 3-20.

Sjöblom, P. (2012). Naturen och jag: En studie av gymnasiestuderandes förhållande till naturen ur ett miljöpedagogiskt perspektiv. Vasa: Åbo Akademi.

Wals, A. (2006). The end of ESD...the beginning of transformative learning: Emphasizing the E in ESD. In M. Cantell (Ed.), Kestävää kehitystä edistävä koulutus -seminaari 15.2.2006 (pp. 41-59). Helsinki: Suomen Unesco-toimikunta.

Wolff, L.-A. (2006). Kestävää kehitystä edistävä kasvatus ja sivistys: Näköaloja korkeakouluopetuksen kehittämiseen (Education and Bildung for sustainable development: A view of the development of higher education). In T. Kaivola \& L. Rohweder (Eds), Korkeakouluopetus kestäväksi: Opas YK:n kestävää kehitystä edistävän koulutuksen vuosikymmentä varten (pp 37-52). Helsinki: Finnish Ministry of Education.

Wolff, L.-A. (2007). The quest for a route to sustainable development in higher education. In T. Kaivola \& L. Rohweder (Eds.), Towards sustainable development in higher education: Reflections (pp. 58-62). Helsinki: Finnish Ministry of Education.

Wolff, L.-A. (2011). Nature and sustainability: An education study with Rousseau and Foucault. Saarbrücken: Lambert Academic Publishing. 


\section{Conclusions}

An intensive Nordic collaboration over 20 years ago has resulted in a shared Nordic definition of nature interpretation. Feedback for the project Nature Interpretation for Children and Young People in the Nordic Countries show that there is still a large and growing interest in nature interpretation in all of the Nordic countries in 2012. Nordic collaboration is an effective method for the development of nature interpretation as an important tool in influencing and implementing nature and environment policies in the Nordic countries.

Nature interpretation includes methods that supplement and compliment teaching in schools and childcare centres, as well as methods that aim to promote ownership and reflection in participants. It is paramount for nature interpretation to create arenas for democratic dialogue on how to achieve sustainable development. Good nature interpretation for children and young people creates these arenas-in this way nature interpretation is an important element in achieving the goals set by the UN's decade for Sustainable Education.

Interest in this project has been great, which was made clear when more than 80 nature interpreters from the Nordic countries responded to invitations to take part in the project. Furthermore, this interest also demonstrated the diverse way in which nature interpreters work. Nature interpretation takes place in places ranging from peri-urban areas to protected natural areas and valuable cultural heritage environments.

Aside from showing that nature interpreters are employed in many different areas and with different types of work, the examples given in this project also show that there is a great diversity of methods used that can inspire other mediators in different ways. The immediate experience is effective, and in this report we demonstrate several examples that can help inspire ways to include and motivate participants in exciting ways.

The seven themes that characterize good nature interpretation is not new knowledge within the field of nature interpretation, but they have not previously been described as a whole, or put into the wider context of nature interpretation. The project group finds these seven themes to be especially important, and we have seen that these themes can function as pointers for the content of education and training of people that work with nature interpretation. Several of the seven themes-like the sections 
on facilitator, ownership, preparation and follow-up-require knowledge, training and experience in order to be mastered and utilised. These are areas that can help professionalise nature interpretation and the specific terms and potential that exists in connection to this profession.

Søren Breiting and Lili-Ann Wolff both address, and shed light, on different themes in detail.

Søren Breiting focusses, in particular, on ownership-ownership meaning an opportunity for participants to take ownership of the mediated themes. This is achieved by presenting participants with real problems that can and need to be solved if we are to further sustainable development. Participants are helped to articulate their own ideas, values and suggested solutions. This has to be facilitated, and that is where the nature interpreter's central role comes into play - the nature interpreter has to master the methods of mediation that further participants' chance to take ownership.

Lili-Ann Wolff's main message is that nature interpretation that promotes participants' desire to be involved with, and take ownership of, sustainable development, has to include three levels. The personal level (our core values and feelings and our own experiences), the social level (our interaction with others, and especially dialogue with others about what we have in common) and finally what she calls the natural level (where we are a part of nature and the world around us). Room has to be made for these levels in nature interpretation. We have to reflect on our own, in conversations with others, and we have venture into, feel and experience nature. This creates the foundation for us as human beings to want, and have opportunity, to contribute to sustainable development.

\subsection{The Wider Perspective}

This project has shown that there still is a great need for developing methods of nature interpretation, and to be inspired by each other across the borders of the Nordic countries. A natural extension of this project would be to develop common Nordic courses for nature interpreters. We are facing a challenge that affects all of us, and this project has shown that we in the Nordic countries work in a goal-orientated and professional manner with nature interpretation as a means to promote sustainable development. The experiences of effective methods of mediation should benefit more people in the Nordic countries. We believe that this can be achieved with an on-going close network of nature interpreters, course organisers and scientists. Shared course modules, 
seminars and workshops will strengthen the methods of nature interpretation. Shared textbooks and other educational material will strengthen Nordic nature interpretation, and the incorporation of new technology mediation and education will create an opportunity to have an even broader reach. In the Nordic countries, we intend to continue working with this.

Not just Nordic nature interpreters have highlighted ownership, involvement and democratic understanding: Together with the Swedish Center for Nature interpretation the international organisation Interpret Europe and the international section of the National Association for Interpretation, based in the United States are co-hosting an international conference for nature interpreters in 2013, the theme is Sharing Our Natural and Cultural Heritage-Interpretation Can Make Us Citizens of the World. 



\section{Sammendrag}

Det fællesnordiske samarbejde "Naturvejledning for børn og unge i Norden" viser, at der i 2012 er en stor og voksende interesse for naturvejledning i alle de nordiske lande. Nordisk samarbejde er en god metode til udvikling af naturvejledning, som et vigtigt virkemiddel til at påvirke og udføre natur- og miljøpolitik i Norden.

Naturvejledning omfatter således metoder, der supplerer og komplementerer den læring, der arbejdes med i skoler og børneinstitutioner, ligesom det omfatter metoder, der søger at fremme ejerskab og refleksion hos deltagerne.

Det er for naturvejledningen afgørende at kunne skabe arenaer for demokratisk dialog, om hvordan bæredygtig udvikling kan opnås. God naturvejledning for børn og unge skaber disse arenaer. På den måde bliver naturvejledning et vigtigt element i at opnå målene i FNs tiår for "Læring for bæredygtig udvikling."

Interessen for projektet har været stort, hvilken blev tydeligt, da mere end 80 naturvejledere i Norden viste respons på invitationen til at deltage i projektet. Denne interesse viste desuden en stor bredde i den måde naturvejledere arbejder på. Der arbejdes med naturvejledning både i bynære områder, i beskyttede naturområder og i værdifulde kulturmiljøer.

Ud over at naturvejlederne er ansat mange forskellige steder og med meget forskellige arbejdsområder, så viser dette projekts eksempler på naturvejledning, at der er en meget stor mangfoldighed i metoder, der kan give inspiration til andre formidlere på flere måder. Den direkte formidling står stærkt, og der er i denne rapport vist en række eksempler, der inspirerer til at inddrage og motivere målgruppen på mange spændende måder.

De syv temaer, der karakteriserer god naturvejledning, er ikke ny viden indenfor naturvejledning, men det er temaer, der ikke er beskrevet $\mathrm{i}$ en helhed eller knyttet samlet til naturvejledning tidligere. Projektgruppen finder de syv temaer særdeles vigtige, og vi ser, at disse temaer kan fungere som pejlemærker for indholdet i uddannelse og efteruddannelse af personer, der arbejder med naturvejledning. Flere af de syv temaer som f.eks. facilitator, ejerskab, før og efterbearbejdning, kræver viden, træning og erfaring for at kunne beherske mestre og anvende. Det er 
områder, der kan være med til at professionalisere naturvejledningen og de særlige vilkår og potentialer, der er forbundet med denne profession.

Rapporten adresserer forskellige temaer, som grundigt belyses. Heraf sættes der især fokus på ejerskab. Ejerskab forstået som deltagernes mulighed for at tage ejerskab til det formidlede temaer. Dette gøres ved at stille deltagerne overfor reelle problematikker, som der kan og skal findes løsninger på, hvis vi vil fremme en bæredygtig udvikling. Deltagerne medformulerer deres ideer, værdier og løsningsforslag. Dette skal faciliteres og det er her naturvejlederens centrale rolle skal komme i spil, for naturvejlederen skal beherske de formidlingsmetoder, som fremmer deltagernes mulighed for at tage ejerskab.

Et andet af rapportens hovedbudskab er, at naturvejledning, der fremmer deltagernes lyst til involvering og ejerskab i den bæredygtige udvikling, skal inddrage 3 niveauer. Det personlige niveau (vores indre værdier og følelser, egne oplevelser), det sociale niveau (vores interaktion med andre mennesker og især dialogen med andre om det vi er fælles om) og endelig det, der i rapporten kaldes det naturmæssige niveau (hvor vi optræder som en del af den natur og den verden, der omgiver os). Disse niveauer skal der gives plads til i naturvejledningen. Vi skal reflektere alene, vi skal i dialog med hinanden og vi skal ud og mærke og opleve naturen. Dette skaber fundamentet for at vi som mennesker har lyst til og mulighed for at bidrage til en bæredygtig udvikling.

Dette projekt har vist, at der fortsat er et stort behov for at udvikle naturvejledningens metoder og at blive inspireret af hinanden på tværs af landene i Norden.

En naturlig fortsættelse af dette projekt vil være at udvikle fælles nordiske kurser for naturvejledere. Vi står overfor en fælles udfordring og projektet har vist, at vi i Norden arbejder målrettet og professionelt med naturvejledning som metode til at fremme bæredygtig udvikling. De erfaringer omkring virkningsfulde formidlingsmetoder bør komme flere til gode i Norden.

Dette ser vi kan skabes gennem et fortsat tæt netværk mellem naturvejledere, kursustilrettelæggere og forskere. Fælles uddannelsesmoduler, seminarer og workshops vil styrke naturvejledningens metoder. Fælles lærebøger og andet uddannelsesmateriale vil styrke den Nordiske naturvejledning og inddragelse af ny teknologi formidling og i uddannelse, vil skabe mulighed for at nå endnu bredere ud. Dette vil vi i Norden arbejde videre med. 


\section{Appendix A/Bilag A}

Disse eksempelbeskrivelser fra 25 nordiske naturvejledere er et produkt af et et-årigt projekt om Naturvejledning for børn og unge i Norden.

Alle eksemplerne er stedbaserede, hvilket vil sige, at de er beskrevet ud fra den lokalitet, som de er planlagt til at foregå i. Her er eksempler som foregår ved havet, langs elven, på fjeldet, i skoven og i mosen, men på trods af dette, indeholder eksemplerne mange gode refleksioner fra naturvejlederne, som kan inspirere til egen metodik og rolle.

\section{Eksempler fra Danmark}

- Byhaver ved havnen i Fredericia.

- Er mosen farlig?

- Liv i lorten.

- Ormen Orla og Renoflex.

- Uddannelse af frivillige i Red Barnet.

\section{Eksempler fra Sverige}

- Djurolympiaden.

- Friluftslivcirkus.

- Fågelexkursion för barn.

- Junior Rangers - Kullaberg.

\section{Eksempler fra Norge}

- Arkeologer for en dag.

- Læring og glede av naturen.

- Naturtypekartleggning i sjøen.

- Undersøkelse af Akerselva. 


\section{Eksempler fra Finland}

- Karin Korsspindel.

- Looking for old-growth forest.

- Mobile learning environments.

- The Grey Ladys fairytale forest.

- The shy and the beautiful, the bold and the ugly.

\section{Eksempler fra Island}

- Vatnshellir - Visit the cave.

\section{Eksempler fra Færøerne:}

- At følge storgærdet.

- Børns nysgerrighed for naturen vækkes gennem jagt på planter.

- Sedna havet, strandzonen og båden.

\subsection{Eksempler fra Danmark}

\subsubsection{Byhaver ved havnen i Fredericia}

Gennem aktiviteter og refleksioner lærer børn at dyrke planter, passe dem og samtidig skabe et grønnere nærmiljø. De lærer at tage ansvar, fordele roller i en gruppe og planlægge et projekt:

- Målgruppe: Børn i alderen 8-13 år.

- Nøgleord: dyrkning af planter, aktivitet over længere tid, ansvar og samarbejde.

- Kontakt: Naturvejleder og lærer, Bjarne Christensen, Borggårdsparken 56, 7080 Børkop Denmark, Tlf: +45 25105552, Mail: Bjarne.Christensen@fredericia.dk

\section{Beskrivelse af eksemplet}

Besøg på havnen med fokus på klargøring af mobile plantekasser. Klassen adopterer seks plantekasser ( 1 meter $* 1,5$ meter) der skal passes igennem hele foråret-sommer-efterår.

- $\mathrm{Kl} .8 .30-9.00$ 
Velkomst og præsentation af klassen og mig selv. Jeg skaber den første kontakt ved at hilse på alle elever/voksne og forsøge på at huske deres navne.

Som opstart på emnet ønsker jeg, at finde ud af hvor meget de ved om det de skal lave. Til dette bruger jeg rewieving (søg på Google: Greenaway). Reviewing skaber et hurtigt overblik over, hvor klassen er henne i forløbet og hvem der har arbejdet med noget tilsvarende før (Måske hos bedsteforældre eller derhjemme). Jeg forventer at klassen har arbejdet med emnet op til besøget, men jeg kan ikke være sikker. Jeg stiller følgende spørgsmål: Hvem ved hvad en køkkenhave er? Hvem har prøvet at arbejde med køkkenhaver før?

- Kl. 9.00-10.00

Eleverne får en rundtur på havnen, hvor jeg viser og fortæller om områdets muligheder. Jeg snakker om: Frugttræer, insekthoteller, bistader, fuglekasser, de fire danske biotoper (eng, hede, skov og strand).

- $\mathrm{Kl} .10 .00-11.30$

Eleverne bliver præsenteret for deres plantekasser. Jeg har været på besøg på skolen for at fortælle om hvad der venter eleverne. Grupperne har derhjemmefra bestemt sig for hvilke grøntsager der skal plantes.

Ifølge aftale med læreren har klasserne brugt tid på at finde ud af hvordan og hvor meget grøntsagerne fylder når de plantes. F.eks. er Squash og ærter er en dårlig kombination idet begge kræver meget plads. Dette har vi snakket om ved mit tidligere besøg på skolen.

- $\mathrm{Kl} .11 .30-12.00$

Eleverne spiser frokost og får selv lov til at gå rundt i området og kigge nærmere på områdets muligheder.

- $\mathrm{Kl} .12 .00-13.00$

Fælles gennemgang og kig på hinandens plantekasser og de overvejelser gruppen har gjort sig i forbindelse med dette. Der skal gøres opmærksom på at dette kun er det første besøg ud af 6-8 besøg. Det er læreren der har ansvaret for forløbet. Naturvejlederen kan bruges som inspirator. 


\section{Materialer og udstyr}

- Håndrive.

- Håndskovle.

- Snor.

- Så-frø.

\section{Klassens forberedelse hjemmefra}

Inden klassen kommer på besøg har den arbejdet med begreberne:

Rodfrugt, økologi, ukrudt, frø, spiring, grøntsager, årstider, vækst, krydderurter, gødning, så.

Inden besøget har klassen fundet ud af hvilke grøntsager der skal såes. Eleverne gøres opmærksomme på at det er deres egne plantekasser. De har selv bestemt hvad der skal i kasserne og den skal følges forår, sommer og efterår. Ved at sige at det er deres egne for eleverne et ejerskabsforhold til kasserne og det er vigtigt i sådan en proces.

\section{Efter besøget}

Klassen skal arbejde med at lave en tidsplan for de kommende besøg. Der skal tegnes/laves en tegning over plantekassens indhold. Der skal arbejdes videre med begrebsarket (se bilag A.)

\section{Om at skabe tryghed i gruppen}

Den første kontakt er altid vigtig. Denne skaber jeg ved at lærer navnene at kende. For at gruppen skal kunne fungere, så er det vigtigt at alle føler sig lige meget værd og det hjælper jeg med ved at lave nogle arbejdsopgaver til alle.

Grupperne består af fire elever for hver plantekasse. Alle i gruppen skal have en opgave:

- En har ansvaret for frøene.

- To har ansvaret for at så.

- En har ansvaret for at skrive ned og tegne, hvad der er blevet plantet.

Begrebskort: Hver gruppe får et sæt kort hvor begreberne: rodfrugt, økologi, ukrudt, frø, spiring, grøntsager, årstider, vækst, krydderurter, gødning indgår (se bilag A). Endvidere findes der nogle opgavekort der bruges til at sætte ord på de enkelte begreber.

Opgavekortene er: 
- Prøv at forklare ordet.

- Sæt ordet ind i en sætning.

- Stav ordet.

- Find et ord der rimer (Se bilag B).

Opgaven går ud på at en af eleverne trækker et kort med et begreb. Herefter trækker man et opgavekort.

F.eks. Jeg trækker først ordret "ukrudt." Herefter trækker jeg opgavekortet Sæt ordet ind i en sætning. Herved laves der en sætning efter eget valg. F.eks: "Jeg vil ikke have ukrudt i min have."

Øvelsen går på skift og alle skal have trukket et begrebskort 3 gange. Disse kort er lavet af naturvejlederen og kan sagtens bruges hjemme på skolen, som genopfriskning af de begreber der skal læres.

\section{Om ejerskab}

Jeg gør meget ud af at fortælle at det er elevernes plantekasser. Eleverne adopterer plantekasserne og derved skaber det et ejerskabsforhold til kasserne. Min erfaring med skolehaver er at elever der har deres "egne" haver/plantekasser vil føle et ansvar over for opgaven og meget oftere besøge stedet end de ellers ville gøre.

Alle elever har Ipad. Opgaven lyder på at tage billeder og lave en logbog for plantekasserne for hvert besøg. Med følgende spørgsmål der skal besvares:

- Hvilken dato har vi?

- Hvad laver vi i dag? (luger, vander).

- Hvad er der sket siden sidst?

- Var der noget der overraskede dig?

- Hvad forventer vi der vil ske til næste gang?

- Tag et billede.

Fredericia er en gammel industriby og vil gerne ændre sig fra at være en grå til en grøn by. Historikken omkring stedet som gammel industrigrund og det fremtidige perspektiv for området er spændende og relevant for byens borgere. Dermed også børnene. Jeg forestiller mig at debatten kunne være muligheden og forskønnelsen af et engang beskidt og lugtende område ved havnen til noget smuk natur i fantastiske omgivelser.

\section{Om samarbejdet med læreren}

Det er vigtigt at have en forventningsafklaring med læreren der kommer med klassen. Hvad er rollefordelingen. Hun/han skal være forberedt på hvad der skal ske. 
Eleverne skal have arbejdet med emnet inden de kommer og læreren skal kende til hendes/hans opgave når plantekasserne påbegyndes.

Endnu mere vigtigt er det at den voksne skal være klar over at besøget ikke kun kan være et besøg, men faktisk 6-8 besøg henover forår og efterår.

Vigtigt at fortælle at det er klassens projekt ikke naturvejlederens. Naturvejlederen kan bruges i starten og til slut eller hvis der er problemer undervejs, men det er vigtigt at understrege at det er klassens projekt og dermed også klassens ansvar at det bliver passet og at læreren sørger for at besøge stedet 6-8 gange i løbet af forår, sommer og efterår.

\section{Om det praktiske ting der vedrører aktiviteten}

Konceptet omkring plantekassernes mobilitet synes jeg er meget spændende. Det er hurtigt at etablere og nemt at få væk igen.

Lad eleverne få et ejerskabsforhold til plantekasserne. Det er min oplevelse at mange elever besøger haverne i sommerferien.

Efterlad altid en logbog og opfordre eleverne til at skrive i den, hvis de har været på besøg i haverne. Det er sjovt at følge igennem ferien, hvor mange der egentligt kommer.

Husk at vise engagement. Det har en meget smittende effekt hos eleverne.

Tabel 8.1. Begrebskort (skolehaver)

\begin{tabular}{ll}
\hline Ukrudt & Frø \\
\hline Grøntsager & Spiring \\
Årstider & Kvadrat \\
Gødning & Vækst \\
Så & $\varnothing$ kologi \\
Rodfrugt & Krydderurter \\
\hline
\end{tabular}

Tabel 8.2. Opgavekort

Prøv at forklare ordet

Sæt ordet ind i en sætning

Stav ordet

Find et ord der rimer 
Billede 8.1. Et meget kreativt eksemplar af en plantekasse

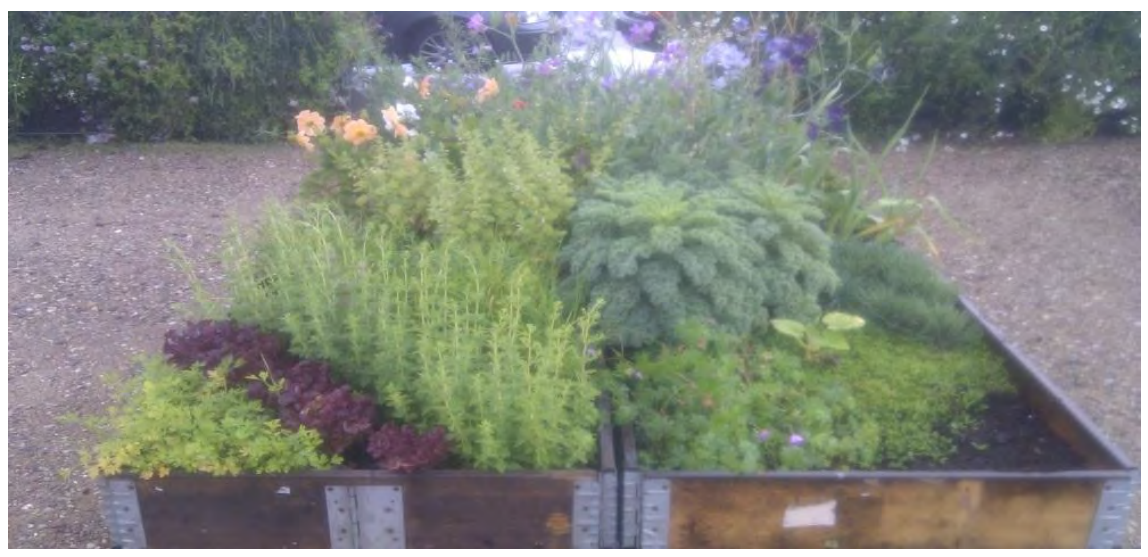

Fotograf: Bjarne Christensen.

Billede 8.2. Mobile plantekasser der hurtigt kan flyttes.

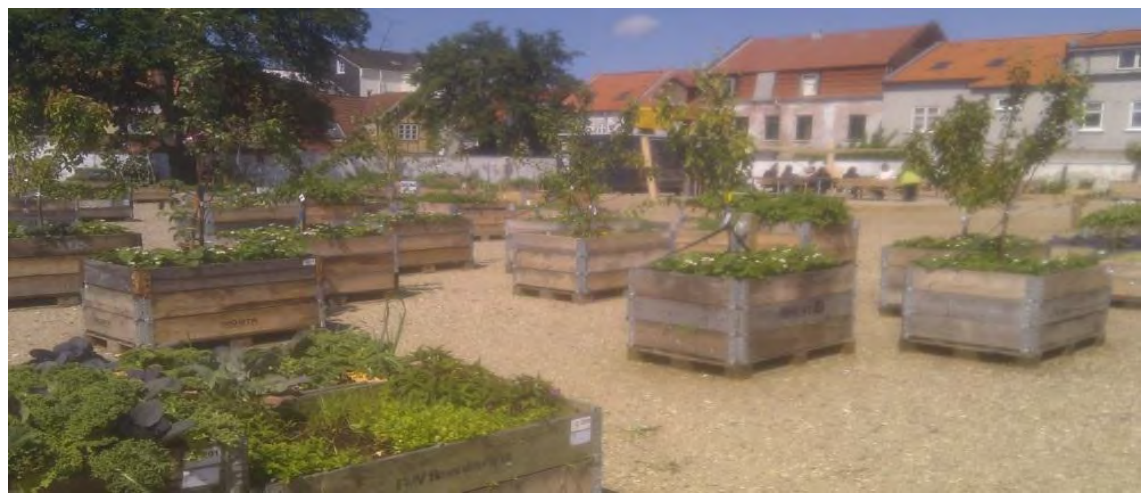

Fotograf: Bjarne Christensen

\subsubsection{Er mosen farlig?}

I denne aktivitet møder børnene mosekonen, som indvier dem i mosefolkets verden. Moselig har de nok ikke kendskab til, men gennem aktiviteter og refleksioner, lærer de mere om mosen og kan begynde at forstå mere af mosens funktion og værdi, både i kulturen og i naturen:

- Målgruppe: 10-14 år.

- Nøgleord: Spænding, involverende aktiviteter, myter og lokalhistorie.

- Kontakt: Vibe Winckles, Naturskolen i Viborg Kommune, Tlf: +45 20199612, Mail:viw@viborg.dk 


\section{Beskrivelse af eksemplet}

Disen ligger tungt hen over mosen, klassen og jeg stopper op på afstand og kigger lidt andægtigt ind over den fra skovkanten. Mosekonen brygger, siger jeg og nogle af eleverne fniser. Jeg dykker ned i min kurv og tager forklæde og tørklæde på, fortæller lidt om mosefolket der boede herude, der levede af krybskytteri og tørvegravning. De troede på lygtemanden og ellepigerne. Når vi går videre ind i mosen er der et par af pigerne, der går tæt, de er lidt bange...

Mosen er sjov at gå på, eleverne ser og mærker tydeligt forskellen fra randen af mosen og ind over spagnumlaget. Det er bedst når alle har gummistøvler på. Sammen vil vi finde ud af hvad mosen er for en naturtype, hvilke planter der lever og hvorfor.

Der samles planter og bestemmes ud fra laminerede ark med moseplanter. Mosevandet smages og PH-værdien måles. Vi har en stang der kan måle dybden af mosen og vi laver stikprøvemålinger rundt om i mosen og regner ud hvor gammel den er. En højmose hæver sig ca. 1 millimeter om året, så måler vi en meter er mosen 1.000 år.

Så er vi kommet langt tilbage i tiden, det er svært at forstå. Men der er næsten altid en der nævner moselig. Hvordan kan det være at mennesker kan bevares i mosen? Jernalderfolket havde en tradition med at lægge folk i mosen, og holde dem fast dernede med pinde, for ca. 2.000 år siden. Ellers ville de være kommet til overfladen og iltet, og derved gået i forrådnelse. Ved at de ligger i mosen er der lukket for ilt og mikroorganismer kan ikke leve i den sure mose. Spagnumplanten har en evne til at ændre på dens omgivelser, så det bliver samme surhedsgrad som den selv. Moseligene er bevaret med deres hår, negle, tekstiler og læder, men hvor alt metal er væk. Vi kigger lidt ned af os selv for at regne ud hvad der vil blive bevaret hvis vi selv en dag bliver lagt i mosen.

Vi tager alle vores ting og trænger nu til en rask løbetur til enden af den Langmose vi er i. Der har jeg lagt handsker, tov, spader og save, for nu skal der naturgenoprettes. Jeg har en aftale med skovfogeden, men han så alligevel forskrækket ud da jeg fortalte ham om den første dag, hvor vi havde "fældet" 550 træer på en dag. Han skulle lige mindes om vores aftale og se de små træer for sig i mosen. Nogen er jo ikke mere end 1 år gamle og nemme at hive op.

Vi tæller dem og eleverne er helt vilde. Konkurrence-genet er i top hos de danske skoleelever. Sidst blev der hevet 2.222 træer op, mon der er nogen der kan stikke den.

Ind imellem samles vi, tæller sammen og bliver kloge på, hvorfor mosen gror til og hvorfor det er godt at hjælpe den med at fjerne træerne. Der er nu så meget forurening i luften at der i mosens øverste lag ikke 
kan blive så surt som i gamle dage, så planternes frø sætter sig fast og gror, derfor gror moserne til.

Heldigvis bliver vi alle sultne ind imellem, så sætter vi os uden for mosen på lidt skrænter og spiser madpakker. Der kan snakken gå om mosefolkets mad, hvad der er spiseligt i mosen og skoven rundt om og tit siger de uhm når vi kommer ind på tranebær. Har vi rigtig god tid laver vi byggrød med tranebær på vores klimaspand.

Inden vi forlader mosen, vil vi prøve at skære tørv med en spade. Det er lidt svært og jeg fortæller om de forskellige metoder der er brugt gennem årene. Jeg har en tør gammel tørv med og vi diskuterer brændeevne, aske og vejrtrækningsproblemer ved brugen af dem.

Jeg fortæller om gamle Niels der bor henne på plejehjemmet. Han var som helt ung ude og skære tørv i mosen alene, kun med sin hund. Han havde problemer med tørveælteværket, det satte sig hele tiden fast, og det sinkede arbejdet hvis han hele tiden skulle slukke for det. Så han sparkede bare til det. Men lige pludselig røg benet med og det kom i klemme i maskineriet, og det kørte stadig...Hjemme på gården gik Niels's mor, hun så hunden var kommet hjem alene og var irriterende pågående. Lige med et vidste hun at der var noget galt i mosen, hun sendte folk derned og Niels kom på sygehuset. De satte benet af og siden har Niels klaret sig med kunstigt ben.

Til afslutning bliver de delt op i små grupper hvor de skal blive enige om hvad en mose er, mens vi voksne går rundt og lytter og giver små fif. Til sidst hører vi det i samlet flok, vi takker af til hinanden og mosen, og tager hjem, efter en natur- og sanseoplevelse af de store. 
Billede 7.3. Planter fra mosen skal bestemmes

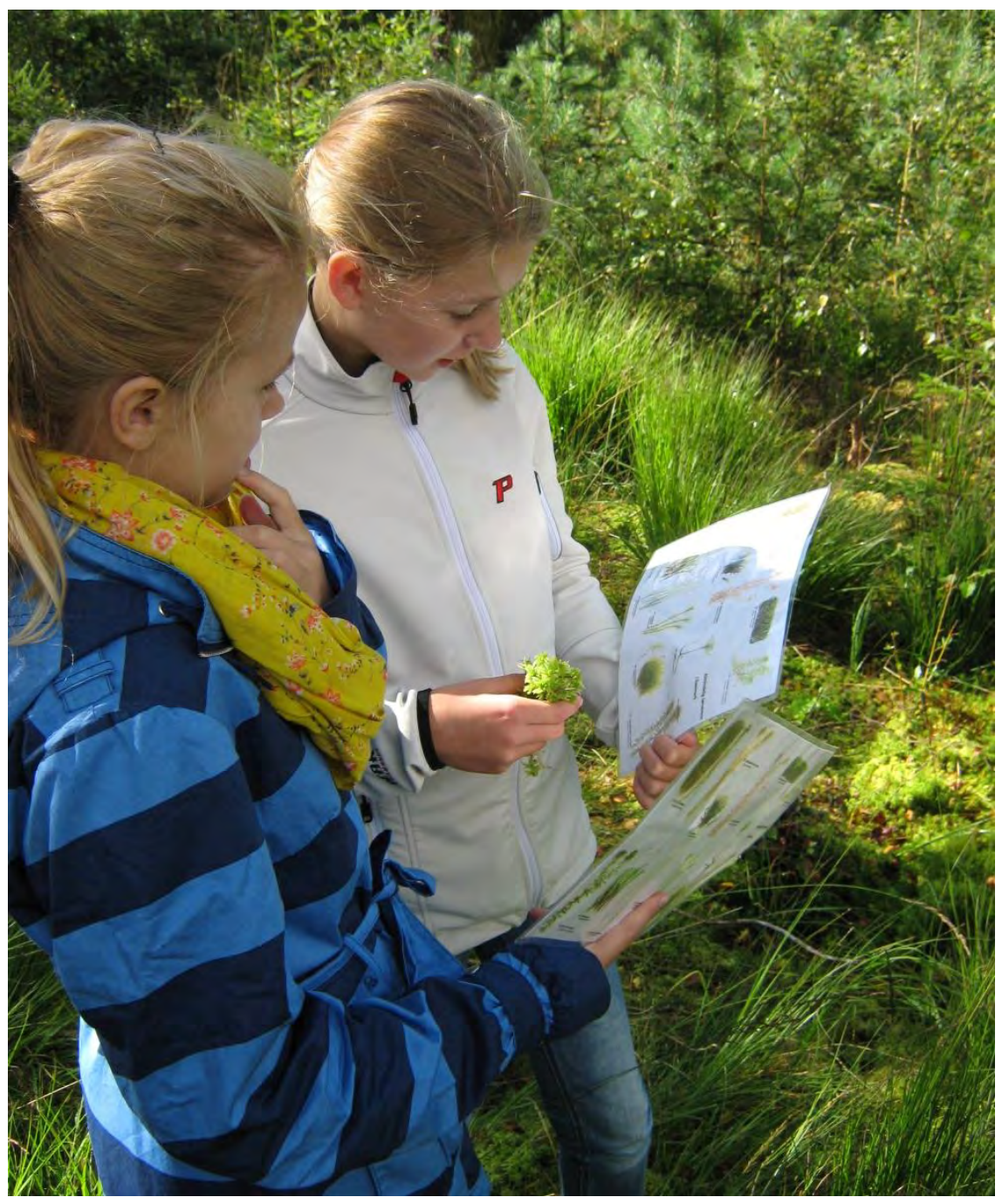

Fotograf: Vibe Winckles.

\section{Aktiviteten i detaljer}

Vi vandrer ud til mosen i lange gummistøvler med grej og madpakker.

På vejen fortælles der folketro-historier om lygtemænd, mosekonen og elverpiger. Så er der lagt op til spænding.

På randen af mosen stoppes op og jeg spørger til naturtyrper. Beskriv en eng, en skov, en $s \emptyset$ og hvad med mosen som vi nu er ved?

Så skal mosen undersøges. Hvorfor er der en mose her? Samling og snak om planter. Jeg har lavet en planche med moseplanter i A4, der er lamineret. De deles i hold og de skal i fællesskab samle så mange forskellige planter ind og navngive dem. Der afsluttes med legen Plantebingo. 
Ph-værdi tages, små børn bruger strips, større børn kan mere nøjagtig måle med Ph-måle instrument. De store børn kan måle Ph-værdien overalt i mosen og skrive det ind på et kort.

Der måles mosedybde med en jernstang. Danske moser gror 1 millimeter om året, så hvis en mose er i gennemsnit 1 meter er den ca. 1.000 år gammel.

Der samles op på vores fælles viden. I grupperne skal de diskutere mine spørgsmål der evt. kan være: - Beskriv mosen, - Hvad kendetegner moser, Hvilke ressourcer gemmer en mose?

Meningsdannende snak om hvorfor moser skal bevares.

Så skal mosen genoprettes! Siden krigen har Danmark mistet $97 \%$ af vores moseareal. Efter en snak om hvordan moser er blevet ryddet, tilplantet og brændt væk for at skaffe brugbar landbrugsjord går vi til et andet hjørne af mosen, hvor den er ved at gro til. Her hiver vi små træer op med rod og fælder de store og tæller dem. Sidst var der en 5 klasse der hev over 2.000 træer op.

Samtidig koges grød af havre og æbler, som mosefolket har spist, på et tørvebål. Det spises sammen med madpakker

Efter maden, graver vi tørv og snakker om mosens arbejdsfolk og at man i over 2.000 år har gjort brugt af mosen. Her kan der snakkes om moselig, myramalm og hvad der kommer op blandt eleverne.

Vi slutter af med tilbagemelding om dagen og drager hjem med grejet.

\section{Materialer}

Save, spader, tov, handsker, laminerede ark med mosens planter, mosebor, PH-værdi strips, gryde, vand, havregryn, æbler, salt, skeer.

\section{Naturvejlederens refleksioner}

Jo bedre man kender og har forståelse for et område/en naturtype, jo flere følelser får man for det og kan derved være ambassadør for det senere hen i livet.

Her får de forståelsen for spagnumplantens evne til at ændre dens omgivelser og at der derved kan opstå en mose.

Forståelse for samspillet mellem menneske og natur viser sig ved drænings- og forurenings-problemet, der er så stort, at moserne gror til. Ved at være med til at rydde for træer, kan de se, at selv en skoleelev som dem selv, kan gøre forskel. Og når de selv har "gjort noget" for den lokale mose, er det nemmere at få følelser for den og få skabt en fornemmelse af ejerskab. Og det er nemmere at tage familien med derud.

Udeskolepædagogikken med undervisning inde-ude-inde er vigtig for denne type naturvejledning. De skal være forberedte før de kom- 
mer og de skal efterbehandle når de kommer hjem for at få det største udbytte af dagen.

Jeg har tænkt at "røre/gøre" - børnene får deres læringsstil/indgang opfyldt.

I det hele taget er her taget hensyn til de fleste af læringsstilene, så der er noget for alle.

Mosen er farlig, mener de fleste. Dansk Litteratur om moser, er næsten alt fra før 60'erne, hvor man arbejdede på at udrydde den naturtype. Danmark har meget lidt mose tilbage, som folk helst undgår, da "man jo ikke går derind."

Moser findes i mange stadier, lige fra vælds-moser-der er ganske ufarlige, tilgroningsmoser med hængedynd og åben sø til højmoserne der er de ældste.

Der er det nemmest at tage de moseområder der ikke har hængedynd, da de voksne er mest rolige ved det.

Find elevernes egen lokale mose og nogle lokale mosehistorier. Det kan være mosefund eller folk der har mistet et ben under tørvegravning osv. Ved at besøge en mose i lokalområdet, forankres oplevelsen og eleverne kan opleve stærkere følelser for området og derved sætter dagens informationer sig bedre fast $\mathrm{i}$ hukommelsen.

\subsubsection{Liv i lorten}

Gennem aktiviteter, sansning, forundring og refleksioner bliver børn og unge ført direkte ind i de spændende liv og den interessante økologi som en kolort gemmer:

- Målgruppe: 12 år-voksne.

- Nøgleord: Mangfoldighed, overraskelse, engagement.

- Kontakt: Leif H. Sørensen, Trente Mølle, Natur-, Miljø og Lokal Agenda 21 center, Trentevej 7, Ny Stenderup DK-5672 Broby, Tlf.+45 62681979, Mail: nv@trente.dk

\section{Beskrivelse af eksemplet}

Målet med aktiviteten er at give deltagerne en oplevelse af den mangfoldighed af liv, der findes i en lort fra forskellige græsædere - herunder kokasser. Med indsigten sættes fokus på begrebet biodiversitet. Samtidig er mange af vores gødningsbiller blandt nogle af vores mest truede insekter. Der sættes fokus på begreber som naturforvaltning, truede dyrarter, menneskets rolle i forvaltning af naturen, betydningen af ændrede landbrugs former, økologisk/konventionelt landbrug millimeter etc. 
Projektet støtter op omkring en række fællesmål for undervisning i den danske folkeskole.

Klassen/gruppen mødes på en egnet lokalitet, gerne et overdrev, hvor der gennem flere år har været en kontinuerlig afgræsning - helst med vintergræsser. Er der på området afgræsning af forskellige dyr, køer, heste, får, geder, diverse hjorte gør det ikke oplevelsen ringere.

Klassen introduceres til området og til den metode, vi skal bruge til at uddrive dyrene fra lortene med.

Der fortælles ikke meget i starten, da der ligger rigtig meget i overraskelseseffekten. Naturvejlederen, viser samlet, med en "udvalgt" lort, metoden. Eleverne får den første aha oplevelse og overraskelse ved at se det meget store antal af biller, der myldre frem.

Klassen deles op i hold på ca. 4 elever. De får udleveret hvert et "ekspeditionssæt," samt et afkrydsningsskema med de på stedet mest almindelige biller. Grupperne sendes ud på små ekspeditioner og skal nu undersøge forskellige former for lort, indsamle en række forskellige dyr (primært biller) og udfylde skemaer for de forskellige typer af lort.

Grupperne samles, og de forskellige biller sammenlignes.

Erfaringer udveksles: Hvor mange arter fandt vi? Var der forskel på arterne i de forskellige gødningstyper?

Naturvejlederen fortæller om forskellige overlevelsesstrategier, om kokassen som levested, et super spisekammer. Alt efter årgang lægges forskellige lag af informationer på. Ved alle alderstrin fortælles om dyrenes betydning for nedbrydning af kokassen og om kampen for at komme først. Er det en varm sommerdag og ser man en kokasse blive "født," iagttages den friske kokasse, og vi ser hvor lang tid det tager før de første dyr indfinder sig. Udvikling i landbruget, naturforvaltningsstrategier, tiger og panda contra månetobist, betydning af mangfoldighed etc.

Med de yngste klasser leges "Banke-Banke lortedyr" for at indlære nogle hovedgrupper af insekter, der lever på lorten.

Evt. snakkes der om aflivning af dyr, i forhold til registrering og indberetning, og der fortælles om hvad der nu skal ske med de data, der er tilvejebragt.

\section{Udstyr til hver gruppe}

1 ekspeditions sæt til ca. 4 personer består af:

- 1 hvidt plastkar ca. 2-4 liter.

- Planteskovl.

- Engangs plasthandsker.

- 2 Skeer (evt. engangs).

- Div. samleglas. 
- Vanddunke ca. $2 \frac{1}{2}$ liter.

- Skriveunderlag/blyant.

- Ark til registrering - her har jeg på forhånd lavet et med de arter, det er mest sandsynligt der vil fremkomme i området. Så er det jo altid sjovt hvis man finder noget andet.

\section{Billede 8.4}

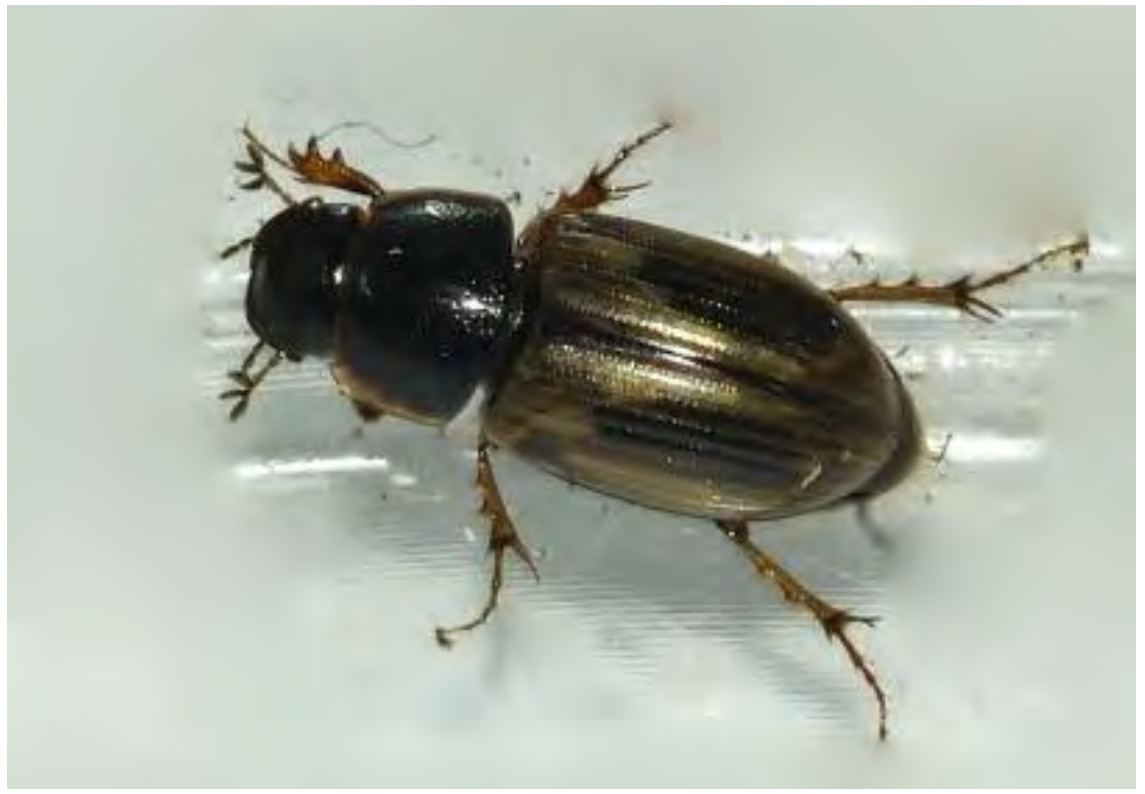

Fotograf: Leif Sørensen.

\section{Fælles udstyr}

- Hvis der ikke er vand til stede, store dunke med masser af vand. Typisk 20-30 liter.

- Affaldssække til brugt udstyr.

- Desinficerende gel til hænder.

- Evt. sæbe, vand og håndklæder.

- Evt. større spade til at vise gravgange under en kokasse.

- Evt. lidt insektnåle og lidt flamingo, så elever kan prøve at opsætte en bille til en evt. lille samling i klassen. (etisk diskussion).

- Alkohol eller eddike-æter til evt. aflivning af dyr.

- Jeg medbringer altid en lille kasse med et udvalg at biller sat op på nål. 


\section{Klassernes forberedelse}

Der kan her vælges 2 strategier:

1. Der lægges ikke op til at gruppen arbejder med temaet før de kommer, da en stor del af oplevelse ligger i wauw-effekten og overraskelsen. Alene det at skulle forholde sig til at rode i kolort. Efter $10 \mathrm{~min}$. så er forbeholdene som regel glemt. I forbindelse med offentlige arrangementer og lignende, så bliver deltagerne oftest taget på sengen, og det var bestemt ikke noget de havde planlagt på forhånd, da de tog hjemmefra.

2. Forløbet kan indgå som en del af et større undervisningsforløb inden for en mængde emner.

a. Økologisk/konventionelt landbrug.

b. Naturforvaltning/naturpleje.

c. Biodiversitet.

d. Truede dyrarter.

Her kan man på forskellige måder arbejde med emnet før og efter - men jeg vil stadig mene, at man ikke skal fortælle eleverne præcist hvad de skal lave, blot måske at man i forbindelse med et givet emne skal ud at arbejde med feltundersøgelser.

Undtaget - hvis det i undervisningen er et vigtig element at lærer eleverne at planlægge og gennemfører en naturvidenskabelig feltunders $\varnothing$ gelse. Her vil det give god mening at eleverne selv fortager en række af de valg og forberedelser som naturvejlederen ellers har gjort.

\section{Efterbearbejdning}

Der er masser af muligheder for at arbejde med det efterfølgende alt efter i hvilken sammenhæng det indgår:

For de mindste klasser kan det indgå f.eks. i temaer med truede dyr. Man kan evt. medbringe lidt dyr fra dagen og elverne kan lave deres egen lille udstilling af dyr, evt. sat på nål. Alternativt kan der laves en udstilling af biller fotograferet på dagen. Det kræver dog et kamera, der kan mere end de fleste elever og skoler har adgang til.

De større klasser kan arbejde videre med naturforvaltnings problematikker, landbrugets udvikling. Der kan lave undersøgelser på økologiske/konventionelt dyrket landbrug. På naturområder, der har haft et langt græsningsperiode contra en "alm. mark" etc. kan lave både kvalitative såvel som kvantitative undersøgelser.

Undersøgelse af energi indholdet i forskellige typer af lort.

Emner som medicinforbrug i landbruget kan inddrages. 
Kokasser som brændsel i tredje verdens lande kan inddrages, og der kan bl.a. bages pandekage over hjemmelavede lerklinede ovne, der fyres op med tørrede kokasser.

Der er i starten en stor usikkerhed ved det at skulle arbejde med ekskrementer. At skulle røre ved dem, og ja de lugter måske heller ikke så rart.

Vi snakker om forskel på lort fra rovdyr kontra græssende dyr. Hvoraf man kraftig må fraråde at arbejde med førstnævnte, da de kan være forbundet med risiko for masser af sygdomme, mens der ikke er problemer med de sidste. Ulækkerhedsfaktoren tales ned!

Alle elever tilbydes engangsplasthandsker, og der tilbydes desinficerende gel til hænder. Evt. findes der sæbe, vand og håndklæder.

Og hvor ulækkert ville det ikke være, hvis vi ikke havde billerne som "skraldemænd."

\section{Om refleksion}

Oplevelse i sig selv skaber en masse refleksioner hos deltagerne.

Men ellers arbejdes der meget med åbne spørgsmål i felten udefra de undersøgelser der laves: Hvordan kan det være at der er forskelle på livet i de forskellige typer af lort og i forskellige aldersstadier af lorten. Hvorfor tror i der er så mange forskellige her og der måske er mindre på en alm. mark? Hvorfor er det fedt at bo i en lort? Hvad kan lorten tilbyde dig som beboer? Spørgsmålene stilles primært i hele gruppen, men også når jeg går rundt til deltagerne der er på "feltarbejde."

At rode i en kolort er for mange en meget grænseoverskridende handling. At røre ved den, lugten og synes at noget pr. definition "ulækkert" sætter i sig selv en masse sanser i gang. Den gamle leg "At træde i kokasse" er desværre en leg i kraftig tilbage gang, og det er ikke lykkedes af få en klasse med på den endnu.

Feltarbejdet - det er helt afgørende at de kommer ned i små hold, der selv skal lave deres egne undersøgelser. Tror aktiviteten ville $\mathrm{d} ø \mathrm{~d}$, hvis det var traditionel klasseundervisning hvor naturvejlederen viste frem.

\section{Om involvering}

De involveres og overraskes primært ved at de forhåbentlig får en oplevelse, de ikke havde regnet med, og som sætter billeder på begreber som biodiversitet og naturforvaltning. At truede dyrearter ikke kun er et afrikansk problem, men også noget vi skal forholde os til i Norden.

At de måske som kommende forbrugere bliver mere opmærksomme på landbruget som forvaltere at dansk natur, og at de derved kan tage mere bevidst valg.

Det er en overraskelseseffekt, at der er så meget liv i noget som vi alle samme kender, men som vi ikke har tænkt over. Det giver den helt store 
aha-oplevelse. Jeg har set selv garvede naturvejledere blive meget overrasket over det liv og den mangfoldighed, der udspiller sig.

Oplevelsen er et rigtigt godt udgangspunkt for en undervisning, der kan gå i rigtig mange retninger. Emnet kan inddrages i mange længerevarende forløb og i mange temaer. På sigt kunne det være spændende at få udviklet undervisningsforløb, i større forløb.

Brug tid på selv at blive fortrolig med de forskellige biller i det område du vil formidle i. Gerne på arts-niveau, men minimum på familie-niveau. Sæt dig ind i biologien for familierne og nogle af de mest fremtrædende dyr. (Møgbiller (Aphodius), Møggraver (Onthophagus), Skarnbasser (Geotrupidae) og Møgkær (Sphaeridium). Samt evt. nogle af de andre man hele tiden støder på, møgfluer sp., Gulvinget flue (Mesembrina meridiana), og rovbiller (Staphylinidae). Der er rigtig mange gode historier. Bruge Mortens D.D. Hansens fremragende hæfte.

Gå i gang. Det er en super oplevelse at have klasser med ud, og se hvordan de går fra afsky til forundring og fascination.

\section{Litteratur}

Hansen, Morten D.D.:-Skarnbasser og andre møgdyr. (Natur og Museum nr. 2 2008). Ljungberg , Håkan \& Krister Hall-Nyckel til svenska dyngbagger-Länsstyrelsen Gotlands Län-2009.

Diverse bind i "Danmarks Fauna."

\subsubsection{Ormen Orla og Renoflex}

(Renoflex er navnet på det firma, som henter affald/skrald i København):

- Målgruppe: 3-6 årige, Børnehaver og børnehaveklasser, grupper op til 25 børn, som kommer for en time med deres pædagoger/lærer.

- Nøgleord: Affald og sortering, Bevægelse og musik, vække forundring uden ord.

- Kontakt: Felix Becker, Urban Miljø- \& Naturvejleder, Vesterbro Miljø- \& Naturværksted, www.traestubben.com, Tlf. +45 20337060, mail: felix.christian.becker@okf.kk.dk

\section{Beskrivelse af eksemplet}

Målet med denne aktivitet er at anspore til bevidsthed og viden om skrald, affald, affaldssortering, kompostering og orme.

Børnene mødes med lyden af en skralde. Jeg (Naturvejlederen) er gemt bag en stor skraldecontainer. Hvor kan i se sådan en skralde? Er containeren fyldt med sådan nogle skralder (instrumentet)? Hvorfor er der en skralde på containeren? 
Billede 8.5

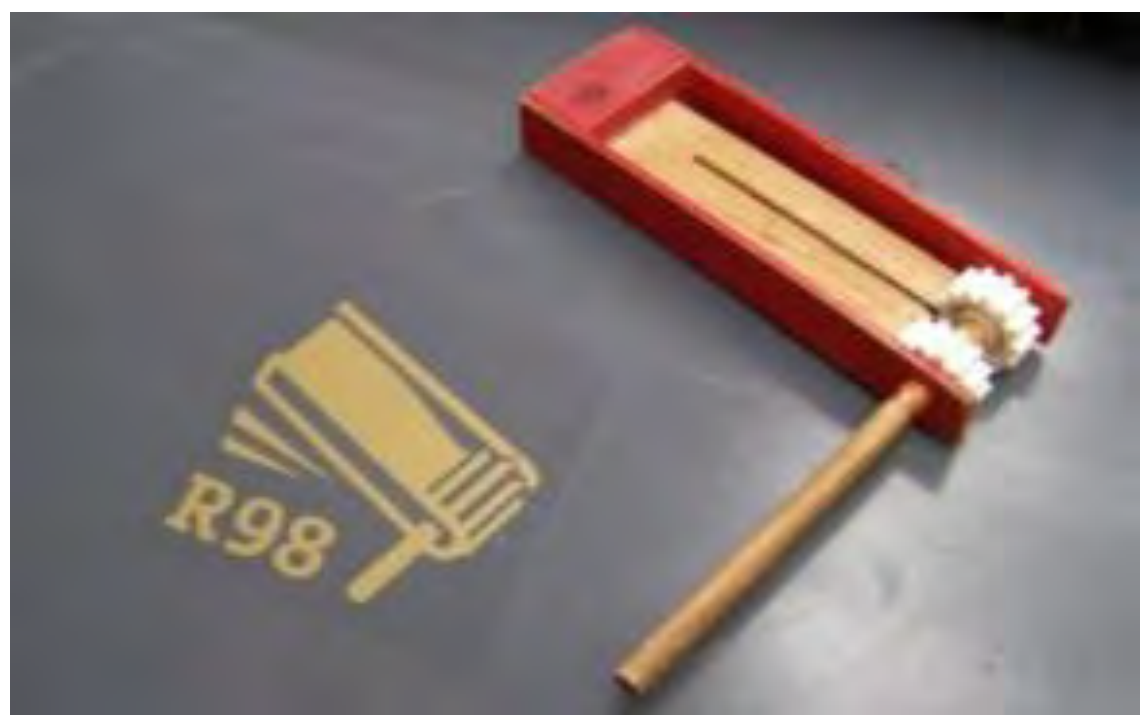

Fotograf: Felix Becker.

Historie: Når den hestetrukne skraldevogn kørte gennem gaderne i gamle dage, gik der en mand foran og svingede en skralde, der larmede, så det kunne høres ind i baggårdene (...).

Tre forskellige skraldecontainere skubbes af børnene til pladsen. Den største køres hen til dockingstationen (et bord) ligesom skraldemændene gør.

Jeg henter en rutsjebane og sætter den på skraldecontaineren og alle børn får en tur ned i skraldecontaineren for at hente én ting op.

Når alle sidder med deres stykke skrald-I restaffaldscontaineren er der alt skrald, som skal sorteres: glas, pap, papir (avis), mælkekarton, gammelt gardin, batterier, farve, køkkenaffald (bananskrald, grene, ...), metal, aluminium papir, el-genstand, et gl. stykke tøj af velourstofsorterer vi det skrald, børnene sidder med i de forskellige containere.

Den røde kasse med dødningehovedet til batterier og andet særaffald.

Vi ender ved noget køkkenaffald. Hvor kommer den hen? Komposthvad sker der? Små dyr bl.a. regnorm. Alle børn får en orm.

\section{Hvordan ser den ud?}

Farve, led, tyk og spids ende, bælte? 


\section{Hvordan føles den?}

Kold og glat med børster. Huden ikke som vores. Regnormens hud er helt tynd og vandet kan løbe igennem den og ind i ormen. Men ormen kan pumpe vandet ud igen.

Hvor er:

- Hovedet? I den spidse ende. Det borer den sig ned i jorden med.

- Numsen? Den anden ende. Den kan sno enden om blade og trække dem med, den bakker ud af sine gange og lægger lort oppe på jorden i små toppe. Sådan kommer jorden væk fra gangene.

- Øjne og mund? Mund i den spidse ende, ikke øjne, som vi kender det. Små organer, som gør at de kan skelne mellem lys og mørke.

- Arme og ben? Det har de ikke, men de har 8 børster, mærk dem. Regnormen bruger børsterne til at holde fast $\mathrm{i}$ jorden med, når den skubber sig gennem den.

- Tissemand og tissekone? I bæltet. De voksne har bælte og de har begge kønsorganer! Men de skal stadig være 2. De lægger æg i en kokon.

Hvad er der mon indeni? Knogler, nej. Lunger, nej. Trækker vejret gennem huden.

Hvor bor de? I lange gange nede i jorden eller i komposten. Den kan ikke lide lys, og tåler ikke at tørre ud.

Hvornår ser vi mange regnorme? Når det regner, så kan den være oppe på jorden uden at tørre ud. Den kommer også gerne om natten.

Det regnede ikke hele juli, hvad gør de så? Kravler langt ned i deres dybe gange, hvor jorden stadig er fugtig. Andre laver sig en lille hule beklædt med slim. Der ruller de sig tæt sammen til et lille nøgle og vente på at regnen kommer. Det gør de også om vinteren.

Hvad spiser den? Blade og jord, men den lever også af små alger, svampe, dyr og bakterier der lever i jorden og på bladene. Regnormen er et af de vigtigste dyr i vores jord. Den er en nedbryder. Den spiser gamle visne blade og andre døde plante- og dyredele. Og så spiser den jord. Den laver muld og graver luftgange til planternes rødder.

Afslutning: Jeg finder det stykke velourstof frem af én af skraldecontainere. Vi klipper strimler af velour gardiner og trækker i dem så de bliver til små orm og som sættes på sytråd.

Alle børn får en orm, som danser på hænderne og gennem fingrene og igennem haven. 
Billede 8.6

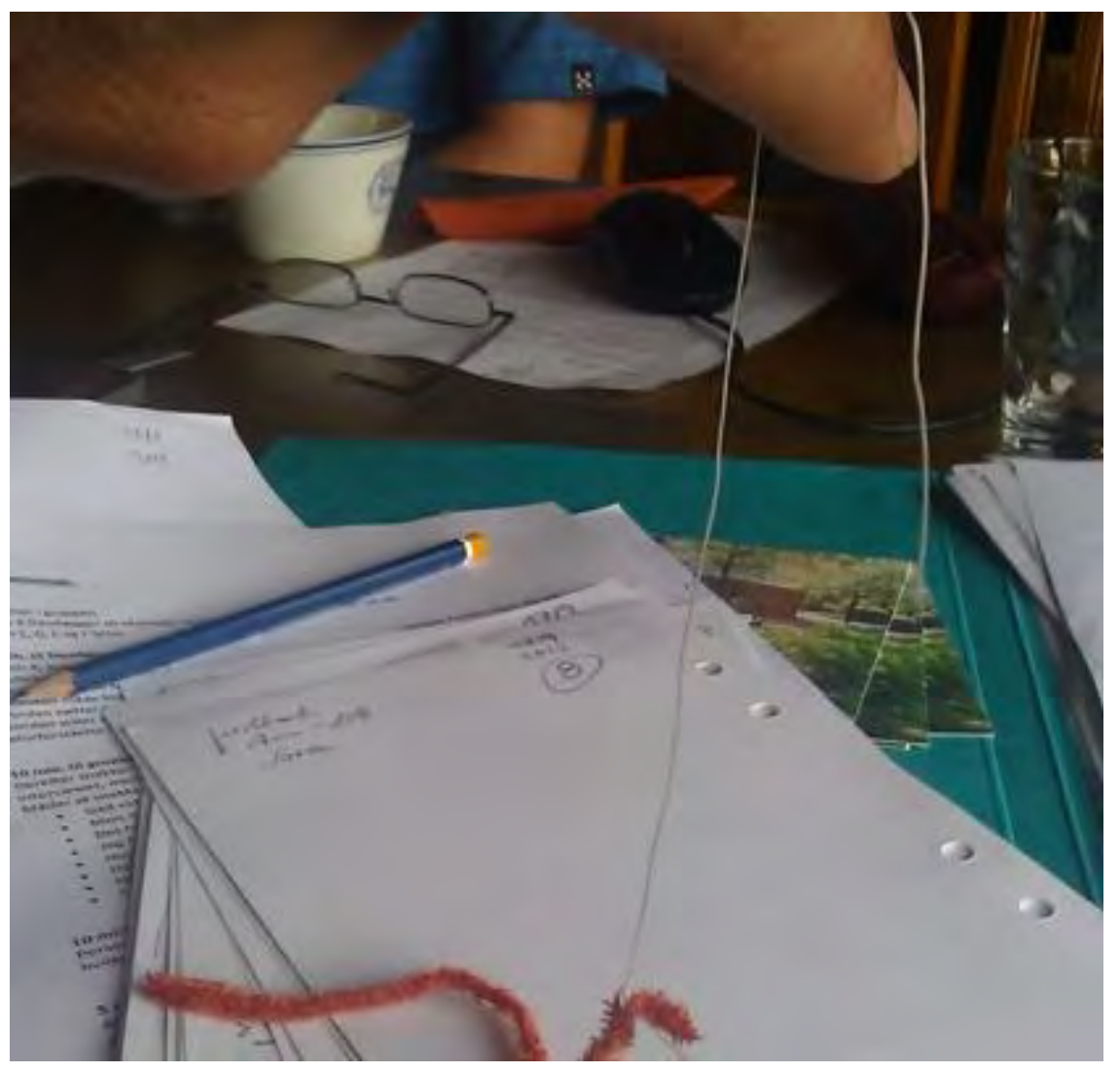

Fotograf: Felix Becker.

\section{Sang}

Krible-Krable Land

Hvis jeg ku'bli'en lillebitte mand(pige, dreng, kone),

Så rejste jeg straks til Krible-krable- land.

Der er så mange sjove små dyr, så jeg kunne rigtig gå på eventyr

I Krible-krable, kravle-krybe, Kilde-land.

\section{Udstyr og materialer}

Hente rene affaldscontainer, samle forskelligt affald, pleje komposten, finde en egnet sang, bygge en rutsjebane af to planker.

Affaldscontainere: restaffald, pap \& karton, papir, batterier, farligt affald (lånt af renoflex), komposten, kurve til glas og genbrug.

Evt. lille skovl og bakker til fremgravning og visning af orme og krable dyr, saks til klipning af orme af velourstoffet, sytråd.

En skralde, harmonika. 


\section{Børneinstitutionernes forberedelse}

Pædagogerne kan forberede/introducere affaldssortering i deres institution - kompost, glas, pap, papir, metal, farligt affald, millimeter.

\section{Det videre arbejde hjemme i børneinstitutionen}

Alle børn går tilbage til børnehaven med deres egen lille dansende regnorm. Det er deres egen. Ormen er synligt for andre og er knyttet til de oplevelser børnene har haft i formidlingen. Alle børn har set og rørt ved en rigtig orm og er selv formidlere af den historie, som udvider sig ved hver samtale og oplevelse ved ormen.

Opfølgningsmateriale til $\mathrm{BH} /$ skoler:

- En pixibog som gave i slutningen af året til hvert barn til læsning med forældrene/søskende/lærere/pædagoger.

- Hæfte "Affald med omtanke."

- Henvisning til bøger på biblioteket.

- Følgeskrivelse: - "få besøg af sorteringsguiden" - hjælp til opstart af kompost i institutioner.

- Til skoler: besøgs ture til forbrændings-anlæg og genbrugscentre.

\section{Billede 8.7}

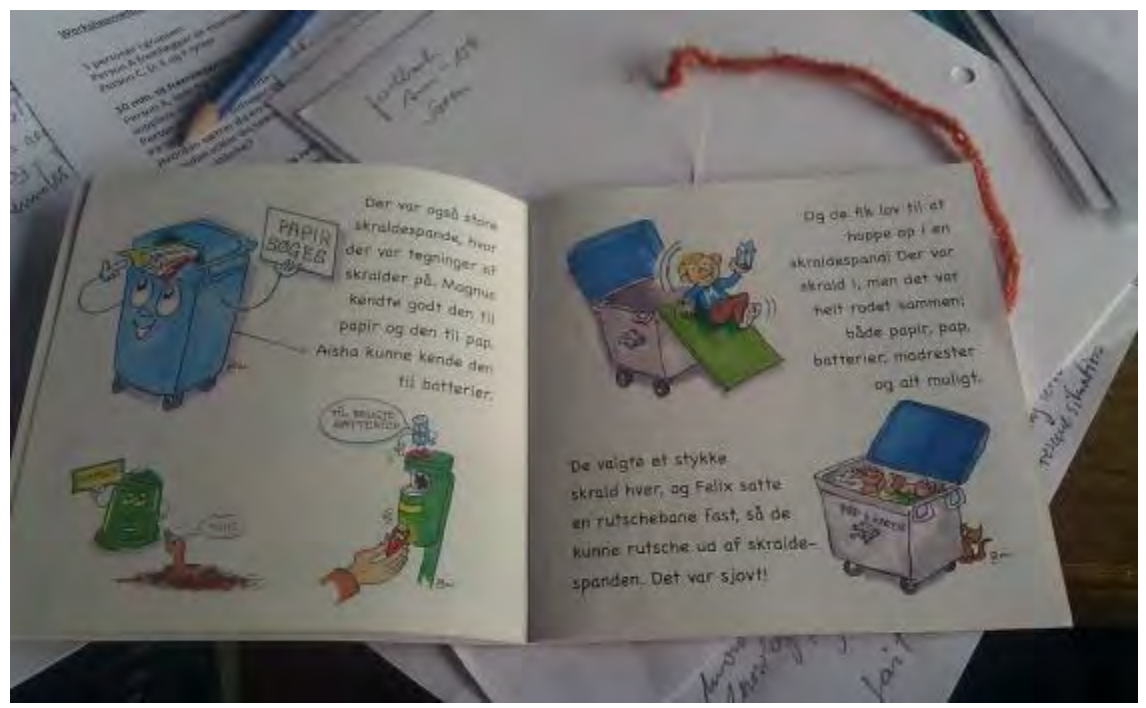

Fotograf: Felix Becker. 


\section{Om tryghed i gruppen}

Leg, lyd, musik og bevægelse og genkendelighed: ex. kan børnene genkende rutsjebanen-et lystfyldt legeredskab på hver legeplads -, som her bliver sat i en anden kontekst. Det nye kombineres med noget kendt og kombinationen skaber forundring, åbenhed og nysgerrighed.

\section{Om gruppens refleksioner}

"Fortæl mig noget nyt om noget jeg allerede ved noget om." Refleksionen kommer gennem forundringen - hvordan kan det lade sig gøre? Hvorfor er der 5 skraldespande? Hvordan er det hjem hos mig? Hvordan er det i børnehaven?

Frem for at jeg stiller spørgsmålene, skal mine opstillinger/scenografi/ objekter, inddragelse og kontrastering af den "lokale normalitet" og hverdagsgenstande stimulere til nysgerrighed og spørgsmål fra børnene.

\section{Om sanser i formidlingen}

Vi har en musisk- sanselig formidlingstilgang. Alle forløb inkluderer inddragelse gennem: rytme, leg, bevægelse, overraskelser, gentagelser, forundring og en dramaturgisk, æstetisk dimension. Hele iscenesættelsen skaber refleksion: De fysiske omgivelser, objekter, hjælpemidler, kontrasterende opstillinger, visualiseringer, historie og historier-spørgsmål og svar.

\section{Det gode råd til andre naturvejledere}

Tag afsæt i det virkelige liv.

Ex.: Lad børnene se, røre, skubbe og undersøge en rigtig skraldecontainer. Arbejd kreativt, skab kombinationer - noget kendt med noget ukendt. Sæt symboler i en udvidet kontekst - skralden-ordspil, symbol, instrument/lyd/musik/rytme/signal og historie.

Lad miljøformidlingen knytte an til dagligdagen. Forbind livs sfærer og fællesskaber. Skab kontraster til normen, normaliteten; skab friktioner, momentan tumult og forvirring, friktioner og grib øjeblikket og tilfælde; inddrag "fejl" og afsporinger som en gave; skab opstillinger og konstellationer, som stimulerer til spørgsmål, frem for at (ud)spørge børnene om deres viden. ... Fortsæt selv!

\section{Om egen evaluering}

Ved refleksion med mine kollegaer og feedback af pædagogerne og løbende modellering af forløbet med nye idéer og erfaringer.

Se nedenfor: "formidlings \& procesudviklings Manual," som jeg løbende opdaterer, omformulerer og komplementerer. 


\section{Manual - et procesværktøj-til det du kan kalde et "progressiv udviklende miljø- \& naturfomidlingsforløb"}

Formål med denne struktur er, at kunne fastholde spontane idéer, impulser, refleksioner, aktualisere, opsummere og udvikle et formidlingstema med størst mulig bevidsthed om elementer, variationer og målsætninger, med sigte på at fri sætte mig (facilitatoren/naturvejlederen) i selve formidlingssituationen.

Baggrund: jeg gentager forløbene mange gange i en projektperiode. Obs.: ofte gennemfører jeg et forløb for første gang ved kun at skitserer et tema og konturerne med få grundelementer op, hvorefter forløbet vokser i mødet med målgrupperne. Derefter hjælper denne opstilling mig at reflektere og fastholde mine praksiserfaringer.

- Billeder/skitser/visualiseringer.

- Emner/formål.

- Målgruppe.

- Ressourcepersoner.

- Brainwind.

- Forberedelserne/opstillinger/scenografi.

- Materialer.

- Værktøj/medier.

- Rekvisitter/kontraster/instrumenter.

- Elementer/variationer/sang/lyde/historier.

- Souvenir.

- Opfølgningsmateriale til børnehaver og skoler.

- Eftertanker/tilbagemeldinger (efter gennemførelsen1., 2. osv. gang).

\subsubsection{Uddannelse af frivillige i Red Barnet til at udføre natur-og friluftslivsaktiviteter med socialt udsatte familier og børn i lokalområdet}

Målgruppe: Red Barnets frivillige i hele Danmark, der deltager i lokalforeningernes sociale projekter i bl.a. de såkaldte "familieklubber" og på lejre/camps.

- Kontakt: Thor Hjarsen, Programkoordinator og naturvejleder, Red Barnet Danmark, Rosenørns Alle 12, 1634 København V, www.redbarnet.dk/natur, Tlf:+45 4011 3373, Mail:thj@redbarnet.dk 


\section{Beskrivelse af eksemplet}

Red Barnet har i disse år stor vækst i det frivillige sociale arbejde i lokalområderne i Danmark. De frivillige laver f.eks. familieklubber og lejre med udsatte familier og børn. Formålet med disse aktiviteter er at give socialt udsatte familier og deres barn:

- Et socialt netværk til andre familier og øger inklusion i og viden om lokalsamfundet.

- Forbedre familiernes relationer mellem børn og forældre.

- Forbedre deres trivsel, sundhed og handlekompetence gennem gode oplevelser og inspiration.

I dette arbejde udgør natur-og friluftsliv en vigtig del, i det mange af de aktiviteter som gennemføres ofte handler om f.eks. skovture, fisketure, lejre, etc.

Red Barnets naturvejleder har derfor til formål at:

- Sikre at natur- og friluftslivsaktiviteterne understøtter de sociale, relationelle og sundhedsmæssige formål.

- Inspirere de frivillige til hvilke slags aktiviteter de kan lave med hvilke målgrupper.

- Sikre at de frivillige har adgang til friluftsudstyr og -grej, kender dets brug.

- Understøtte at de frivillige samarbejder med andre naturvejledere i Danmark, samt friluftsorganisationer, der kan hjælpe med at gennemføre aktiviteterne.

Dette eksempel handler om at udvikle og støtte de frivillige i Red Barnet i at kunne gennemføre natur- og friluftslivsaktiviteter med det socialt udsatte familier og børn. Erfaringerne vise, at arbejdet indebærer en række udfordringer, som skal håndteres:

Væksten i antallet af frivillige og antallet af aktiviteter. Gennem det seneste 2 år har Red Barnet oplevet en voldsom vækst i et frivilligt socialt arbejde med udsatte familier. Denne vækst ventes at fortsætte og stiller derfor store udfordringer til den form for kursusaktivitet omkring natur- og friluftsliv, som Red Barnets naturvejleder hidtil har tilbudt frivillige.

Hvordan skal naturvejlederens arbejde organiseres således at de sociale, netværksskabende og sundhedsmæssige målsætninger for de sociale aktiviter når flest frivillige? Vi regner nemlig ikke med at kunne øge personaleresurserne væsentligt! 
Spredningen af viden og inpiration - effektivitet? Endelig er der også effektivitetet i kurserne og møderne med de frivillige som skal redesignes. Hidtil har kursusvirksomheden foregået som følger med i gennemsnit årligt:

- 2-4 weekendkurser "24 timer i det grønne."

- 1-2 legekurser.

- 1 nationalt fælleskursus.

- 2-3 regionale/lokale 1-dagskurser.

Hertil kommer, at naturvejlederen deltager i konkrete natur-ture i familieklubberne - f.eks. en skovtur - men der er stor efterspørgsel på naturvejlederen. Og da turene/lejrene kun kan foregå lørdag-søndag samt i visse ferier, er naturvejlederen booket 6-7 måneder frem i tiden!

Kurserne udbydes i direct mail til frivillige, samt på Red Barnets web for frivillige.

Derudover beskrives tilbuddene fra naturvejlederen i en særlig brochure rettet mod de frivillige, se: http://www.redbarnet.dk/Materialer-tilfrivillige.aspx?ID=497\&ProductID=PROD249.

Hvad skal de frivillige lære? Nu snart "Level Two!"

Gennem de seneste 1-2 års kursus og inspiration af frivillige, samt støtte til dem, i brug af natur- og friluftsliv, har det for naturvejlederen handlet om at få dem til at:

Være opmærksom på natur- og friluftslivets værdi som socialt rum for mennesker. Hvad kan naturen bruges til? Hvilke positive effekter er der - også socialt - ved at lave aktiviteter i naturen?

Give økonomisk støtte til at familieklubber og lejre kan komme på tur i naturen - dvs at de kan modtage penge til f.eks. mad, transport og udstyr.

Give inspiration til aktiviteter omkring bål, bålmad, lege, samt f.eks. brug af kniv og økse.

Opbygge en "grej-bank," hvor de frivillige kan låne udstyr som f.eks. bålgryder, telte, knive og økser, reb, soveposer, liggeunderlag, etc.

$\mathrm{Nu}$ efterspørger de frivillige, som længst har været i gang, ideer til nye aktiviteter i naturen som kan tiltrække de deltagende familier og børn. Der er i visse tilfælde en tendens til afbud og frafald af de socialt udsatte familier, hvis ikke de frivillige kan præsentere et "lækkert og spændende" indhold for de deltagende familier.

Samtidigt handler det også om at de frivillige skal kunne eftergøre og replicere de aktivitetsforslag som naturvejlederen kommer med. Det skal ikke være aktiviteter som kræver certifikater eller dyrt specialud- 
styr (som f.eks. kajak eller klatring) og yderligere skal aktiviteterne være inkluderende, så alle kan deltage, stort set uanset fysisk og psykisk form.

Dvs der nu i høj grad er behov for at kunne anvise nye og attraktive aktiviteter, som de frivillige kan gennemføre, og som samtidigt opfylder de sociale, trivselsmæssige og handlekomptenceforøgende formål for familier og børn, der deltager i Red Barnets frivillige sociale aktiviteter.

Fremadrettet arbejdsprogram for naturvejlederen og Natur \& Fællesskab mhp at kompetenceudvikle de frivillige til at bruge natur og friluftsliv i deres frivillige sociale aktiviteter i Red Barnet:

Uddannelse og inspiration af frivillige: For at imødekomme den kraftige vækst $i$ antallet af frivillige og for at nå så mange frivillige som muligt vil der blive lavet to weekendkurser årligt med fokus på natur og friluftsliv. Kurserne foregår i naturen med overnatning i shelter, telt, lavvu el. lign og de frivillige laver mad over bål. Kurserne handler både om at skabe sociale aktiviteter, understøtte gode relationer mellem familierne, samt lave meningsfulde, trygge naturaktiviteter.

Desuden laves korte 1-dags kurser og workshops lokalt med grupper af frivillige, der står for den samme familieklub eller lejr. Sådanne kurser vil kunne gennemføres 3-6 gange årligt.

1-2 gange årligt afholder Red Barnet desuden et nationalt frivilligseminar, hvor op mod 80-120 frivillige deltager. Her foregår en lang række aktiviteter og workshops sideløbende, og én workshop vil skulle handle om natur-og friluftsliv.

Endelig skal der udarbejdes en manual/håndbog i brug af natur-og friluftsliv i det frivillige sociale arbejde.

\section{Udstyr og forberedelse}

Natur\&Fællesskab og Red Barnet har gennem de seneste 6 år anskaffet sig en mængde friluftsudstyr som kan understøtte aktiviteterne. En del af dette udstyr er samlet på en centralt lager, og administreres af naturvejlederen.

En del anden udstyr har en hel del udstyr som anvendes mhp inspiration, f.eks. snitteknive, bålgrej, økser, reb og tov, etc.

Lokalforeningerne og de frivillige kan (langtids-)låne grej fra Red Barnet til deres aktiviteter.

Red Barnet har desuden pakket 12 "friluftskasser," der ligeledes kan lånes af de frivillige. Alle disse kasser blev udlånt på mindre end 4 måneder.

\section{Naturvejlederens refleksioner}

Der bruges en række metoder til at skabe tryghed hos henholdvis de frivillige og de deltagende forældre og børn.

De frivillige: Kurserne i friluftsliv, sponsorering af grej, økonomisk tilskud til friluftsaktiviteter, samt etablering af partnerskaber er alle metoder 
til at gøre de frivillige selvhjulpne til at lave friluftsaktiviteter - enten selv eller i samarbejde med f.eks. partnerne. Desuden kan naturvejlederen deltage på familieklubbernes aktiviteter og på lejrene i begrænset omfang - og det sker gerne i starten af klubbernes/lejrenes levetid - og derved gives der tryghed i forbindelse med måske nogle af de første friluftsaktiviteter som de frivillige skal stå for. Desuden afholdes der planlægningmøder forud med de frivilige, eller planlægningen foregår over mail eller telefon, så de opnås en forventningsafstemning og tryghed hos de frivillige.

På selve aktiviteterne forsøges det at naturvejlederen træder i baggrunden, således at de frivillige selv kan stå for aktiviteterne.

Den tætte kontakt og relationsdannelse til de frivillige er væsentlig, så de kender Red Barnets medarbejdere, og føler at der er let adgang. Det handler om at skabe tryghed blandt de frivillige i at bruge natur og friluftsliv.

Frivilligkurserne tager udgangspunkt i egen-oplevelser med naturen i barndommen og bevæger sig hen over målsætning, tryghedsskabelse, inddragelse og ender i praksisexempler og metoder, samt huskelister.

De socialt udsatte familier og børn (målgrupperne): På aktiviteterne arbejdes meget med god og sunde relationsdannelser indenfor familierne, mellem familierne, mellem de frivillige og familierne, samt mellem de frivillige.

Red Barnet søger at få deltagerne til at føle sig set og inkluderet, bl.a. ved at inddrage deltagerne i planlægningen og i selve aktiviteterne. Vi har f.eks. erfaring med afholdelse af børnemøder på lejrene hvor børnene med til at forme aktiviteterne.

På lejrene og i aktiviteterne arbejdes med aktiviteter der styrker disse relationer og skaber tryghed. Det kan f.eks. være:

- Goddag og give hånd når vi mødes.

- Lege som er sjove og fælles.

- Bålaktiviteter som skaber tryghed.

- Aktiviteter hvor deltagerne hjælper hinanden f.eks. laver mad, snitter sammen, finder vej etc.

På kurserne for frivillige og inspirationsmøder anvendes en hel del tid på at stimulere til:

- Refleksion om egen praksis og egne roller.

- Hvad der har betydning for børns oplevelser ("dit eget bedste minde som barn").

- Hvordan sætning af mål på langt og kort sigt er med til at forme aktiviteterne og netop vores egne roller. 
Evalueringer og vidensindsamling gennemføres med f.eks. spørgeskemaer der skal udfyldes af de frivillige efter hver aktivitet. Heri angives både kvantitative og kvalitative resultater.

Jeg bruger altid egen-oplevelser som afsæt for kursusaktiviteterne for frivillige.

Jeg anvender mange eksempler for at illustrere min pointer om f.eks. de socialt inkluderende aktiviteter.

Kurserne er en kombination af viden, egen refleksion og praktisk læring - forsøger at tale til så mange "læringsstile" som muligt hos de frivillige på kurserne.

\subsection{Eksempler fra Sverige}

\subsubsection{Djur-olympiaden}

Bra information om hur du kan göra skyltar för indirekt naturvägledning. Bra grund för fundering varför djurens förmågor och beteenden varierar: människan är inte skapelsens krona:

- Målgrupp: Barn 5-12, t.ex. fritids och barnfamiljer.

- Nyckelord: Djur, biodiversitet, ekologi.

- Kontakt: Sofie Lindblom, Föreståndare naturum Hornborgasjön, www.hornborga.com, Tlf: 010-224 56 59,

Mail: Sofie.lindblom@lansstyrelsen.se

\section{Beskrivning av exemplet}

Många barn har en stor nyfikenhet för djurs förmågor och rekord. Genom att leka med tanken att tävla mot djur kan man få in reflektioner om evolution och djurens roll i ett ekosystem.

Detta är utformat som en aktivitet för att engeagera barnfamiljer på besök i ett naturreservat under några få timmar t.ex. under ett sportlov för dem som inte har möjlighet att åka iväg till fjällen eller liknande. Den kan självklart göras även vid andra tillfällen. Det kan anpassas om till den miljö man är verksam i och välja de deltagande djuren därefter. Självklart kan gruppaktiviteter inkluderas, men det har inte varit aktuellt ihop med barnfamiljer på dagsutflyckt, men passar självklart om man har en skolklass som redan känner varandra.

Grenarna som fanns var sex till antalet och hade alla på något vis koppling till att på ett lekfullt sätt jämföra sina fysiska egenskaper mot nordiska djur. 


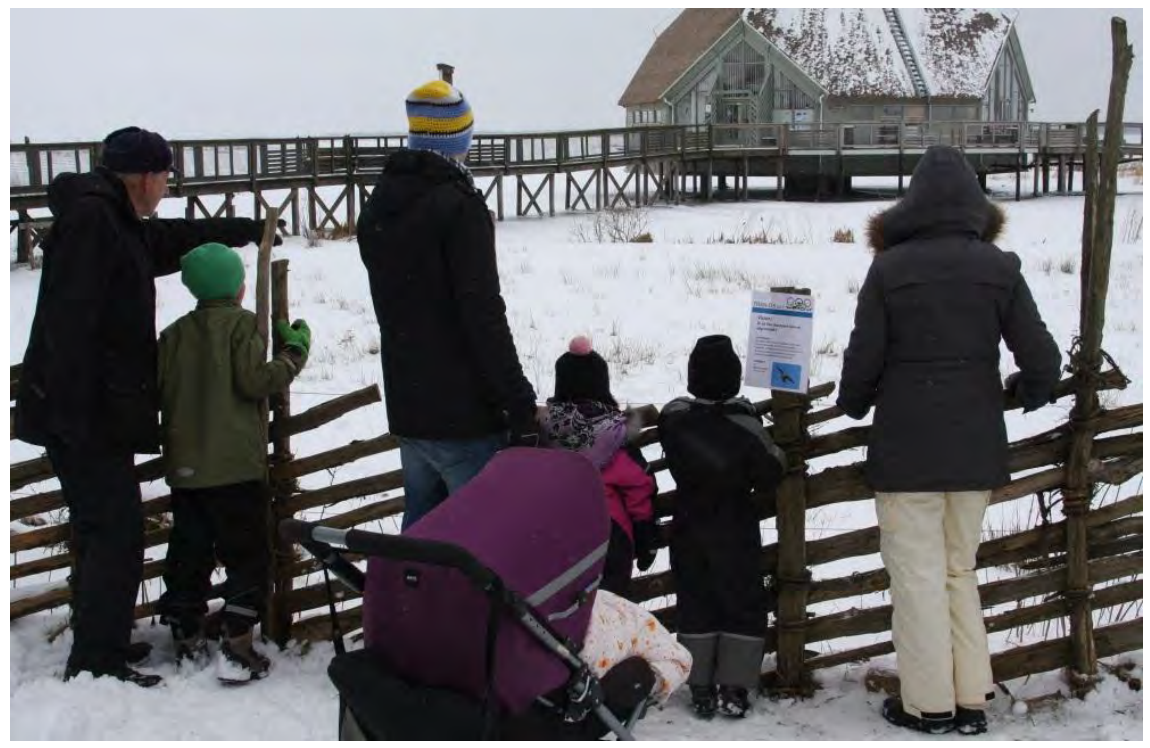

Fotograf: Sofie Lindblom.

- Löpning: Springa 50 meter och jämföra tiden mot; älg, räv, fälthare, husmus och igelkott.

- Längdhopp/tre-steg: Tävlade mot lodjur, fälthare, åkergroda, husmus och loppa.

- Höjdhopp: Jämföra sin längd mot trana, lång snok och sedan försöka hoppa och klappa högsta älgen på ryggen.

- Bygga bo: Med hjälp av vedklabbar skulle man bygga så högt torn som möjligt och jämföra mot rekord myrstacken 2,8 meter. I skogen kan detta göras med de pinnar man hittar, ungefär som natur-jenga.

- Syntest: Jämföra sig mot blicken av en pilgrimsfalk och hitta 10 små möss (bilder) placerade på ett utmarkerat område av för platsen lämplig storlek. Detta kan lätt göras till en kikar-övning t.ex. lära sig använda en tubkikare. Placera då mössen ännu längre bort men var noga med att förklara vart ramarna för området det skall leta i finns.

- Flygning: Vika pappersflygplan och färglägga dem som tranor (välj flyttfågel som passar i din miljö) för att sedan flyga från Hornborgasjön till fyra utmarkerade poster längs en bana. Det provades många modeller och alla lyckade ta sig till stolpen för häckningsplatsen i Bergslagen, några kom fram till rastplatserna i Tyskland (Rügen) och Frankrike (Lac du Der) och de riktigt duktiga flygarna kom ända til övervintringsplatsen i Spanien (Extremadura). 


\section{Naturvägledarens förberedelse}

Det behövs skyltar till alla olika stationer. Dessa skrivs ut och lamineras. Detta eftersom den kan fungera som en typ av indirekt naturvägledning och därför ska kunna stå för sig själva utan förklaring. Dock är det självklart möjligt att genomföra aktiviteterna med t.ex. en skolklass och då behövs inte riktigt lika mycket skyltförklaringar.

- Löpning: Mät upp 50 meter sträcka. Informationsskylt om utmaningen med bild och deltagarlista. Stoppur. Startsnöra och stopp snöra ett lägga på marken. Målskylt. Resultattavla med djurens hastigheter omräknade för sträckan 50 meter

- Längdhopp/tre-steg: Informationsskylt om utmaningen med bild och deltagarlista. Avstampsmarkering t.ex. snöre på marken. En skylt per djur som deltar i tävlingen med bild och hoppresultat. Placera skyltarna på rätt avstånd från avstampssmarkeringen. Mät upp och markera ut landningsplatserna.

- Höjdhopp: Informationsskylt om utmaningen med bild och deltagarlista. En skylt per djur som deltar med deras höjd/längd. Mät ut och placera skyltarna på rätt nivå t.ex. längs en trädstam.

- Bygga bo: Informationsskylt om utmaningen med bild och deltagarlista. En stor hög med pinnar eller vedträn. En filt eller sittunderlag att ställa knän på om snöigt. Tumstock för mätning.

- Syntest: Informationsskylt om utmaningen med bild och deltagarlista. Tio bilder på möss som skrivits ut, formklippts, laminerats och sedan häftats fast på tunna pinnar som kan stickas ner i marken eller snön. Markering för vart man skall stå. Till exempel mur eller ett staket. Eventuellt kikare om man väljer att markera ut ett större område.

- Flygning: Informationsskylt om utmaningen med bild och deltagarlista. Papper för vikning. Vikningsinstruktion för flygplan, färgpennor. En skylt per flygdestination som placerad ut längs en åk-bana.

Fika som pris för gott deltagande. Någon form av eld (OS-elden). Kan tändas innan barnen kommer eller som en inledningscermoni ihop med barnen innan tävlingarna startar.

Det tar en del tid att förbereda alla skyltar. Se till att allt är på plats i god tid. Då detta görs på vintern kan man med fördel även förbereda fika med varm choklad när man sitter och viker tran-planen.

\section{Målgruppens förberedelse och efterbearbetning}

Läs gärna på om våra nordiska djur så att barnen känner igen tävlingarnas deltagare. 
Presentera gärna djuren på ett så fysiskt sätt som möjligt (bilder, dockor, charader) och håll dig till djur som finns i ditt område för att förankra naturupplevelsen mer till platsen.

Fortsatt reflektion över vilka som vann. Försöka hitta och fundera över förklaringen till djurens förmågor och beteenden. Sätta in det i ett större samanhang; räven vill äta haren och därför måste den kunna springa ikapp den. Medan haren vill springa ifrån räven för att slippa bli uppäten, därför måste den kunna springa ifrån den. Ibland vinner den ena ibland den andra, därför blir det oavgjort i loppet.

\section{Naturvägledarens reflektioner}

Jag deltar alltid själv i tävlingarna (även fast jag gärna ser till att inte vinna... utan snarare hålla jämna steg). Som naturvägledare måste man visa att det är kul. Jag försöker även locka med föräldrar eller fritidsledare att delta. Då vågar fler barn leva ut än om de vuxna står brevid och bara tittar.

Jag ställer frågor till barnen både innan tävlingen, vem tror ni vinner? Och efter; varför kom räven och haren på delad tredje plats i sprintloppet? Varför är igelkotten så långsam?

Det här är en aktiv typ av naturförmedling där hela kroppens fysik måste vara med. Synen testas bokstavligen i utmaningen med pilgrimsfalken.

En ökad facination för djur i vår närhet ökar intresset för naturen i stort. Människan presenteras väldigt ofta som skapelsens krona och vi har känslan att vi kan styra och bestämma allt. Det är därför en ganska befrinande tankelek att ihop med barnen upptäcka att det finns förmågor som andra djur besitter som överträffar våra egna. Målet är att skapa en reflektion där barnen blir medvetna och nyfikna på de arter vi delar vår natur och närmiljö med, men också förhoppningsvis i längden få en reflektion över att det inte är en självklarhet. Utan bygger på att vi människor "tillåter" och bevarar miljön där de bor.

Genom att fysiskt testa på dessa aktiviteter kommer informationen förhoppningsvis fastna tack vare upplevelsen och känslan i kroppen och förstärkan den i utvärderingen av resultaten.

Barn har ofta redan relationer till våra större däggdjur och det är ett fantastiskt tillfälle att låta dessa historier flöda fritt under till exempel flygtävlingen då vi fikar och viker fågel-flygplan. Låt barnen berätta om sina djurmöten. Hur såg det ut där? Varför finns älgen i skogen och musen vid huset etc. Dessa historier triggar ofta även föräldrar som i sin tur delar med sig historier till gruppen. Välkomna denna interaktion, då det förhoppningsvis stärker en fortsättning på naturupplevelsen även då familjen lämnat aktiviteten eftersom de delat en erfarenhet. 
Ta hellre färre stationer närmare varandra än hitta på en massa som du inte kan överblicka. Om du väntar stora grupper, ta hjälp och var fler vägledare.

Detta skall helst inte bli för mycket av en sportslig tävling mellan barn, då de som känner sig obekvämma med idrottstävlingar. Fokusera på att det är "alla vi" som människor som tävlar mot djuren. Det kommer dock alltid vara något djur som springer långsammare (igelkotten) hoppar kortare (loppan) etc. Då kan man fokusera på det men ta upp frågan; varför? Igelkotten kanske inte behöver vara snabb och loppan hoppar långt i förhållande till sin storlek. Styr om fokus från barnens prestation.

\subsubsection{Friluftslivcirkus}

Social samvaro i nya omgivningar.

- Målgrupp: Ungdommar.

- Kontakt: Peter Eriksson, Stensjögård pl 281, 76010 Bergshamra

\section{Beskrivning av exemplet}

Bakgrund: Vi lever i en tid då allt färre barn och ungdomar från urbana miljöer hittar ut i naturen genom sina föräldrar eller på annat, samtidigt som media dagligen rapporterar om olika typer av miljöorienterade problem som vi hoppas att "nån" ska lösa. Vidare tror jag att vi har goda skäl att tro att naturkontakt i unga år och därigenom föda ett vurm för natur och miljöfrågor är en bra förutsättning för att i framtiden kunna fatta kloka och hållbara beslut, oaktat om det är ur ett privat eller professionellt perspektiv.

Utifrån detta har tanken om en lägerverksamhet för barn och ungdomar i väglöst land fötts, där friluftsliv och cirkusträning blandas med lägerlivets kvalliter. En korsbefruktning av två verksamheter som inte har tävling som primärmål, fokus ligger snarare på individuellt växande med nya upplevelser och insikter genom lägerliv.

Verksamheten/Lägren: En större mängd ungdomar (30-60 pers) som praktiserar lägerliv i väglöst land (skärgård eller skog/fjäll) under en vecka. Login är i lappkåtor eller på skutor. Vi blandar klassiska friluftslivsaktiviteter med cirkusträning. Alla deltagare deltar aktivt i alla sysslor under veckan vilket ställer krav på ansvar, organisation och samarbete, detta gör vidare att lägret blir som ett minisamhälle där praktiska sysslor blandas med äventyr och upplevelser på ett okonstlat sätt. För många av deltagarna är denna vecka första steget till en närmare relation till naturen. 
Då vi tror att samtalet och dialogen har en central roll för att befästa nya insikter, tankar och upplevelser avslutas varje dag med att vi alla sitter i en ring runt en eld och dryftar dagens eskapader i lågornas sken. Här ges ofta goda förutsättningar för att lyfta frågor som rör samhället istort. Då lägret är i väglöst land tar frågorna ofta avstamp ur nomadfolkens perspektiv. Hur mycket prylar behöver jag egentligen, när är det dags att flytta, hur stor är min eller min grupps miljöpåverkan, går det att leva utan el, osv.

Stort fokus första dagen ligger även på att skapa trygghet och tillit i gruppen, därför gör vi ett antal samarbetsövningar, både i större och mindre grupper där det centrala är att främja samarbete både utifrån ett teoretiskt/samtals perspektiv till ett praktiskt/operativt, från tanke till genomförande.

Dessa läger är ofta en samproduktion av olika aktörer från både den kommersiella och ideella världen. Organisationerna bidrar inte bara med ett monetärt stöd utan även med volontärer som är med som lägerledare under lägret. Denna mix av ledare från olika delar i samhället bidrar till dynamiken och breddar perspektivet på de frågor och reflektioner som kommer upp under veckan. Dessutom gör det att "nätverket" runt verksamheten får en bredare spridning, och som slutligen gör att de problem som kan uppstå under planeringen lättare låter sig lösas oavsett om det gäller praktiska eller ekonomiska frågor.

Slutligen, lägrens primärmål är att nära det frö som finns i djupet av alla människor som säger oss att "allt hänger ihop, separation är en illusion." Att känna snarare än att teoretiskt analysera, att delta snarare än att konsumera, att vara snarare än att prestera, och för detta finns inget bättre forum än naturen.

\subsubsection{Fågelexkursion för barn ... med värsta pippi- historierna om starar, talgoxar, hackspettar med flera}

- Målgrupp: Små barn 3-6 år.

- Nyckelord: fågelförmedling, lek och aktiviteter.

- Kontakt: Michaela Lundell, Naturskyddsforeningen, Tel: +44 070 2844075, Mail: Michaela.lundell@glocal.net

\section{Beskrivning av exemplet}

Precis när jag började känna mig varm i kläderna som naturvägledare för barn gav mig denna workshop så många nya tankar och idéer. Det var för väl att Sören vid genomgången sa att det är bättre att försöka 
förbättra sig i små steg, än att försöka göra revolution och göra om allt från början. Hellre bygga på det man har, det är mer hållbart.

Konkreta förslag att använda ovanstående i min fågelexkursion för barn. Jag spånar: Vad ska vi göra? Titta på fåglar! Vad behöver man då? Vad heter en sån där som är så bra på fåglar och jämt spanar efter dem? Ornitolog, jaha! Vad behöver en sån? Kikare! Ur en stor väska plocka fram kikare som jag gjort av toarullar, som deltagarna får hänga runt halsen. Alternativt, ta med materialet, och vi börjar med att tillverka toarullekikare tillsammans.

Och så måste vi ha krysslistor! Krysslistan kan få ha med några påhittade arter, för att få in humor. Inte för många arter på listan, det viktiga är inte att visa hur många fåglar jag själv kan identifiera, utan den ska vara något roligt, som aktiverar deltagarna. Kanske finns bara sex fåglar på listan, som vi säkert kommer att se, plus något väldigt ovanligt (man kan ha placerat ut något i förväg, en skämtsak, kanske några hönsägg som man målat prickiga och lagt i ett bo man själv gjort, så att man kan kryssa den väldigt sällsynta, exotiska "prickiga pippin").

Innan familjerna slår sig ner för att äta matsäck, får varje familj bygga ett bo av vass, som vi plockar vid strandkanten. Sedan får "fågel"familjerna sätta sig i sina bon, och man kan t.ex. låta barnen vara föräldrafåglar och mata sina (riktiga) föräldrar, som får tigga om mat.

Tid för lekar:

- Fågel-karaoke. Jag spelar upp ett läte, och visar bild på fågeln i fråga, och någon ska härma lätet. När den prövat några gånger, och det börjar låta bra, applåderar vi allihop, och sedan, när vi alla vet hur den låter, bildar vi en "kör" och alla gör det lätet tillsammans.

- Uvar och korpar. Frågesport där deltagarna delas in i berguvar och korpar (berätta att de fått sina namn efter hur de låter: Bubo bubo resp. Corvus corax, eller svenska "korp"-låt alla pröva lätena), som står i två linjer mittemot varandra. Om svaret på frågan är sant/ja, ska uvarna jaga korparna, som kan rädda sig bakom en linje. Om svaret på frågan är falskt/nej ska korparna jaga uvarna. Blir man tagen går man över till andra laget.

- Kungsfågelleken. Kullek med olika trofinivåer. Hoppstjärtar, som kullas och "äts" av spindlar, som kullas och "äts" av kungsfåglar, som tas av sparvhöken eller kölden. 
- Fågelquiz med fingret på näsan. Jag ger ledtrådar, och deltagarna ska gissa vilken fågel jag avser. T.ex: Man brukar säga att den här fågeln är vit och svart. Den bygger stora bon, som kan ha flera våningar. Den knycker gärna mat från andra djur. Ofta träffas de många tillsammans och skrattar och skränar i buskarna. Efter varje ledtråd får deltagarna en stunds betänketid, och när de tror att de kommit på det rätta svaret, ska de sätta ett finger på näsan. Men nästa ledtråd kanske omkullkastar det man trodde var rätt, då kan man ta bort fingret igen. Bra metod, där man tävlar mest mot sig själv, eftersom inga svar sägs ut högt under gång. Till sist kan någon få berätta svaret.

- Skatleken. Deltagarna delas in i skatpar, som vart och ett ska samla tjugo pinnar var att bygga ett bo av. De ska "flyga" (flaxa med vingarna) och får bara hämta en pinne i taget. Boet ska bli så stort att båda får plats att stå i det. När de är klara med sitt eget bo ska de flyga iväg och knycka pinnar från andra skatpars bon. De får bara ta en pinne i taget, och ska lägga tjuvpinnarna i sitt eget bo. Man håller på så länge det är roligt.

- Fågelbingo. Deltagarna får "bingobrickor" med några av de arter man kan förväntas få se eller höra uppskrivna, och varsin penna. Turen blir då samtidigt ett bingospel, och barnen kan få något när de fătt "bingo," t.ex. näbbar tillverkade av äggkartong. Antingen tillverkar man näbbar tillsammans på plats, eller så har ledaren förberett dem. De kan vara målade i olika färger, och kan i sin tur bli ingången till en diskussion om hur olika näbbar ser ut, och vad fåglarna använder dem till.

Man kan t.ex. börja med en fågelquiz eller fågelkaraoke, och när man kommit till skatan, kan man fortsätta med att fråga vad mer deltagarna vet om skator. Sedan kan man leka skatleken. Sedan kan man gå och titta på de riktiga skatornas bobygge. Det räcker att leda dem åt rätt håll, och låta dem själva hitta bona. När man väl ser skatorna kan man fråga dem om färger. Tycker de också att skatorna är vita och svarta, eller vilka färger ser de? På dessa sätt får barnen med flera sinnen upptäcka och lära sig om fågeln, hur den lever och vad den gör. De får bidra med sina egna kunskaper och sin fantasi. Dessutom får de röra på sig, håller sig varma och har roligt.

Sång och ramsor: Använd fågelsånger, fågelramsor, gärna med rörelse. Sången "tio fina fåglar, satt på en gren, en ramla ner, då var de bara: en, två, tre, fyra, fem, sex, sju, åtta, nio fåglar kvar. Nio fina fåglar satt," osv. Då kan man ha med sig bilder/fågeldockor som föreställer olika arter, sätta upp dem på en gren, och så får deltagarna turas om att peta ner dem en efter en under sången. 
När man berättar om ramsor, för att känna igen och komma ihåg hur olika fåglar låter, kan man berätta hur ramsorna är på olika språk. På svenska ber bofinken sin mamma om att få gå på bio, men på engelska ber din sin mamma om bröd och ost.

Överraskningar: Man kan ha med sig en liten modell av en cykel (gärna lite gnisslig) som man kan plocka fram ur fickan när man ska lyssna efter kungsfågeln. Låta någon deltagarna hjälpa till att snurra på pedalerna och få modellen att gnissla ("Kungsfågeln låter som någon som sitter och cyklar på en gnisslig liten cykel uppe i en gran).

Man kan gömma en blå slips under tröjan och plocka fram den när man pratar om blåmesarna. Berätta om hanarnas kamp om honorna.

Mera: En fråga att ställa på en sådan här tur, för att få barnen att börja diskutera, är "vad kom först, ägget eller fågeln?"

Ta med mig en jordglob, för att kunna berätta om vart fåglarna tar vägen när de flyttar, hur de rör sig utan att bry sig om de nationella gränser vi människor satt upp. Prata om vad som i stället kan vara hinder för fåglarna. Om det finns deltagare som vuxit upp någon annan stans på jorden, är det också ett tillfälle för dem att få visa var. Man kan jämföra längden på flytten (som förmodligen var omvälvande för barnet, även om sträckan är kort), med den fåglarna gör, varje år.

Man kan lägga in ett moment där man bygger fågelholkar tillsammans och sätter upp dem, alt att de får ta med sig dem hem.

\section{Några saker jag tar med mig}

I stället för att fokusera på vad jag vill berätta för barnen, vill jag nu mer fokusera på vad barnen redan vet, och utgå ifrån det.

Låta dem fatta en del beslut själva under aktiviteten. Allt för att öka deras känsla av "ownership"/mentalt ägarskap och övning i demokrati, genom att deras synpunkter är viktiga och påverkar vad som händer, vad vi gör och ser.

Souvenirpedagogik: Jag strävar efter att använda så lite utrustning som möjligt, och vill allra minst skapa nya prylar. Helst vill jag bara ha människorna och miljön, inget mer behövs. Men souvenirpedagogik tål att tänka på. Vad skulle de kunna ta med sig hem från aktiviteten som minne? Om det nu inte är en "pryl," vad skulle det kunna vara då? Kanske en sak gjord av återvunnet material skulle kännas okej.

Lämna gott om tid för reflektion, i stället för att fylla hinken full. Kanske ska jag avsätta mycket mer tid för deltagarnas reflektion (och min egen) än för ny kunskap.

Humor. Vill jag gärna använda mer. Överraskningsmoment. Våga släppa in det mer och även planera för det. 


\subsubsection{Junior Rangers-Kullaberg}

- Målgrupp: Årskurs 9 och första årets gymnasium (2012).

- Nyckelord: Ungdom som naturguider, ungdom ledar ungdom.

- Kontakt: Daniel Åberg, Naturum Kullaberg, Tel: 040-252392, Mail:Daniel.aberg@lansstyrelsen.se

\section{Beskrivning av exemplet}

Syftet er att visa unga människor vägen till natur- och kulturhistoria genom olika aktiviter i grupp i området kring Kullabergs naturreservat och Kullabygden.

Målsättningen med projektet är att ungdomarna i samarbete med Kullabergs "Rangers"', natur- och kultur föreningar och berörda by-, vägoch intresseföreningar, utför gemensamma natur och kultur inriktade aktiviteter vilket bidrar till ökade möjligheter för demokratiska processer och större samförstånd för natur och kulturvärden. Ungdomarna blir en del i Europarc federation vilket kan bidra till framtida arbetstillfällen inte bara i Sverige utan också i andra europeiska länder. De får också möjligheten att lära från och samverka med människor från olika samhällsklasser och åldersgrupper, som har lite kontakt i dagens samhälle.

Under 2012 har vi tio ungdomar (sju tjejer och tre killar) som deltar i Junior Rangers- programmet på Kullaberg. De är under hela programmet anställda av Höganäs kommun som betalar för tre veckors sommarjobb på Kullaberg (fem i varje grupp om tre veckor vilket ger sex veckor totalt).

Ungdomarna skickade in en ansökan till Höganäs kommun där 27 möjliga valdes ut för intervju hos oss på naturum Kullaberg. Efter intervjuerna på naturum valde vi ut tio stycken som skulle få chans att vara Kullabergs första Junior Rangers.

Junior Rangers jobbar ett betalt sex timmars arbets- pass varannan söndag där deras arbetsuppgifter består av allt från att underhållsarbete på befintliga leder, anläggningar och kulturellt värdefulla fastigheter eller besöksplatser som t.ex. badplatser. Röjning eller restaureringsarbete av olika naturtyper är också en stor del av arbetet likaså att bistå i naturum med att informera och guida våra besökare.

Det ingår också att under året medverka vid minst fyra tillfällen i de lokala natur och kultur inriktade föreningarnas program aktiviteter.

Under sommarsäsongen som är deras kommunalt betalda sommarjobb är deras huvudsakliga arbetsuppgift naturguidning och information i naturum blandat med renhållning och skräpplockning samt underhåll av rastplatser. Dessutom arbetar de aktivt med att fungera som handledare för yngre barn som besöker området och leder vårt ungdomsprogram "naturdetektiverna"' vilket är inspirerat av WWF och av befintliga 
program från nationalparker i USA. Där får barnen möta en Junior Ranger för en halv dag och får tillsammans i grupp eller med föräldrar utföra olika naturinriktade uppgifter som sedan belönas med diplom och en liten bricka/knapp där det står Naturdetektiv på.

Genom ett samarbetsprojekt med The Peak District National Park, har Junior Rangers möjlighet att åka till England för att tillbringa en vecka tillsammans med en grupp engelska ungdomar som har koppling till Peak District National Park. Det är tänkt att Kullabergs Junior Rangers och de engelska ungdomarna ska utföra något projekt tillsammans i The Peak District. Junior Rangers kommer också få möjligheten att upptäcka området på egen hand och att delta i olika aktiviteter som de själv ska välja. Förhoppningsvis kommer en grupp från England (kanske redan till hösten) för att besöka oss på Kullaberg.

\section{Inför ett arbetspass}

Utrustning och material anpassas till varje träff. All utrustning som används lånas från Kullabergs naturreservat. Junior Rangers får grundläggande information om nästa arbetspass vid avslut av pågående pass. Därefter skickar vi ut fördjupad information via deras mail och deras egen facebooksida som är ett öppet forum där vi diskuterar uppgiften och svarar på frågor. Ungdomarna deltar i att skapa det slutgiltiga upplägget för arbetspasset. Junior Rangers tar ned sig arbetskläder och egen matsäck och passets arbetsledare har med sig övrig utrustning som kan behövas inklusive första hjälpen låda.

Arbetspasset börjar med att vi samlas och hälsar varandra välkomna och arbetsledaren kollar av "dagstatus" och frågar hur alla mår och försöker "ta in alla." Arbetsledaren frågar om deras förra arbetspass och tar sig tid att lyssna in från alla. Detta får dem att känna sig sedda och hörda vilket skapar trygghet och de får en möjlighet att reflektera. Arbetsledaren presenterar sedan arbetsuppgiften igen och beskriver arbetets olika praktiska detaljer och diskuterar dem med gruppen. Om andra samarbetspartners finns på plats som t.ex. den lokala Naturskyddsföreningen eller en byaföreningen kan det vara de som håller i denna del. Detta skapar en samhörighet och en gemensam ansvarskänsla "ägande" av uppgiften. Teamkänsla uppstår.

Allt arbete utförs i grupp och om möjligheten finns så blandar vi upp Junior Ranger gruppen med medlemmar från närvarande förening. Arbetsledaren deltar också genom hela arbetspasset. Under arbetets gång pratar man med varandra om allt möjligt och en trygghet skapas. Vi fikar sedan tillsammans och även här får man möjlighet att integrera med varandra. 


\section{Utvärdering}

Vid första träffen/arbetspasset tillsammans skriver ungdomarna ner på ett papper om vad de hoppas att få ut som Junior Rangers. Deras förhoppningar och drömmar lämnas då till ansvarig ledare för programmet och läggs i ett kuvert för att delas ut först efter sommarsäsongen. De läses inte av någon innan dess. Ungdomarna får tillbaka sitt papper vid sommarsäsongens slut och reflekterar över tankarna som fanns då och hur det blev och vi diskuterar framtiden för programmet i grupp.

Det är meningen att dessa ungdomar skall bli handledare för nästa grupp som skall sättas igång i april och de ska följa dem fram till och med juni då de själva avslutar med att medverka på Europarc Federations årliga internationella Junior Ranger Camp. Så hur upplägget blir för nästa års nya Junior Rangers skapas utav nuvarande grupp. På så vis hoppas vi på att programmet kan leva vidare utan att vara beroende av en "eldsjäl" vilket ofta inte är hållbart under en längre period.

Röda tråden förJunior Rangers Kullaberg är att vi vill att våra ungdomar ska inspirera och leda andra ungdomar att hitta vägen till en berikande fritidsaktivitet i samband med naturen.

Genom att läta gruppen vara aktiv i planeringen av nästa års program (genom deras egna reflektioner och funderingar), vet de att Junior Rangers-programmet är ett program där de kan påverka planering och genomförande. Ungdomarna informeras under sin tid som Junior Rangers varför de gör det de gör. Vi pratar och diskuterar under dagen medan vi är ute och jobbar. Genom att ha en kontinuerlig dialog är ämnet alltid framme under ett sex timmars arbetspass. Under våren har vissa Junior Rangers visat ett allt större intresse för natur/kultur/miljölärandet. Det viktigaste är att låta Junior Rangers vara delaktiga i planeringen av programmet, samt ta vara på kunskapen som redan finns hos dem.

En grundlig utvärdering kommer att göras under hösten 2012 efter ett planerat besök till The Peak District i England. Utvärderingen kommer att användas för vidare utveckling av Junior Rangers på Kullaberg. Ett krav från Leader är att Junior Rangers också ska redovisa och utvärdera sin Leader-ansökan vilket ytterligare ger möjlighet till reflektion, eftertanke och utveckling.

\section{Läs mer}

Junior Rangers på Kullaberg följer Europarc Federations riktlinjer för Junior Rangers: http://www.europarc.org/what-we-do/junior- ranger Mer information om europarc kan hittas på:

- http://www.europarc.org/home/ 
Mer om Kullaberg Junior Rangers:

- http://hd.se/hoganas/2012/05/27/sommarsasongenfick-flygande-start

- http://hd.se/hoganas/2012/04/29/kullaberg-har- fatt-sina-junior kullens-junior

\subsection{Eksempler fra Norge}

\subsubsection{Arkeologer for en dag}

Formålet er å bruke deltakernes nysgjerrighet og få dem til å forstå vår rolle i historien. Ved hjelp av jordprofiler får de en fin inngang til hvordan det ser ut $\mathrm{i}$ jordbunnen fra naturens side, og hvorfor det gjør det.

- Målgruppe: 8-12 år.

- Nøkkelord: arkeologi, nysgjerrighet og vår rolle i historien.

- Kontakt: Stein-Roar Slotterøy, Dalane Friluftsråd, Tel: +47 90134393, Mail: naturligvis@friluftsrad-dalane.no

\section{Beskrivelse av eksemplet}

Prosjektet forklart nedenfor er direkte rettet mot barn i skolealder (612 år). Det fremmer den praktiske gjennomføring av undervisning og stimulerer til aktiv generell utviklingen av individet i sammenhengen med andre og miljøet. De som deltar er ikke en passiv tilskuer, men er aktiv med i gruppe prosessen:

Barna får selv prøve seg som arkeologer. De får tildelt en rute på 1 x 1 meter hvor de skal gjøre en arkeologisk utgraving. Her må de bruke metodene de har lært og forsiktig skrape av lag for lag av jorden.

Når de gjør arkelogiske funn skal de som en arkeolog registere funnet. De skal dokumentere funnet i et skjema og beskrive i hvilket jordlag de fant det. De skal fotografere og ta vare på funnet slik en arkeolog gjør.

De ulike gruppene kan få funn fra forskjellig tidsalder. En gruppe kan ha steinalder, en gruppe kan ha vikingtiden og en gruppe kan ha middelalder. Deretter kan man legge dette etter hverandre på en tidslinje eller samle de tingene, som hører sammen i ulike grupper.

En annen ide for gruppen kan være å knuse et kar og grave ned de ulike bitene i utgravingsfeltet. Barna skal derettter grave ut krukken og sette sammen bitene igjen. Klarer de å finne alle? 
Bruk av moderne teknologi som å bruke en metalldetektor til hjelp i letingen. Her kan man lete etter mynter, materialer fra vikingetiden osv.

Som en del av arbeidet kan barna gjøre en jordprofil. De kan grave et hull i bakken ca. 1 meter. og se på de ulike jordlagene. Ulike jordlag fortelles oss mye om historien til stedet vi er på.

I et første forberedende stadium blir nysgjerrigheten til deltakerne stimulerte med en introduksjon: som hva er arkeolog, hva er din jobb, hvordan brukes instrumenter og hva er et arkeologisk stratigrafi.

Hvis man kan er besøk i et felt hvor det pågår utgravning det beste. Hvis ikke kan man lære mye av å besøke et grustak eller lignende for å se på ulike jordlag.

Det å prøve å være arkeolog kan være en introduksjon til historieundervisningen.

\section{Nødvendig materiell}

- Areal til simulering av utgraving.

- (3 meter x 2 meter), tre høyde om 30 centimeter.

- Ulike typer av tomt som er lett å skille.

- Reproduksjoner av arkeologiske funn, graveskjeer, grafser hansker. skjermer, store børster, og øsekar.

- Kort for klassifisering av materialer.

- Kamera.

- Ta kontak med lokale museum og høre om de har uregistert matrialer man kan få låne.

\section{Etterbearbeidning}

Forklare til barn hvorfor forskning på arkeologi er viktig for historien Nå er du klar til å møte en ekte stratigrafisk utgraving (oppdagelsen, gjenoppbygging og påfølgende katalogisering av materialet selv) ved hjelp av verktøy og teknikker.

\section{Om aktiv deltagelse}

Det fremmer praktiske gjennomføring av undervisning og stimulerer til aktiv generell utvikling av individet i sammenheng med andre og miljøet. De som deltar er ikke en passiv tilskuer, men er aktivt med i gruppe prosessen.

\section{Om refleksjon}

Samle gruppen på slutten av dagen og summere opp og repetere.

Stille spørsmål som: 
- Hva er en arkeolog?

- Hva er strategrafi?

- Hvorfor er det viktig å gjøre en utgraving før vi bygger ut et område?

- Hva gjør vi med det vi finner? Hvorfor?

- Hva kan det vi har funnet, fortelle oss?

- Hva gjorde folk før TV var oppfunnet?

- Hvem bodde i Norg før oss?

Alt dette for å stimulere den intellektuelle kapasitet til barna og for å gi de et annet syn på virkeligheten som vi lever i, men samtidig huske verdien av vitenskap og historie.

Faktisk utfordres deltakerne å ta tilbake materialer og prosessorteknologi som moderne mennesket har glemt. De lærer igjen å ta i bruk elementer dannet naturen. 
Bilde 8.9

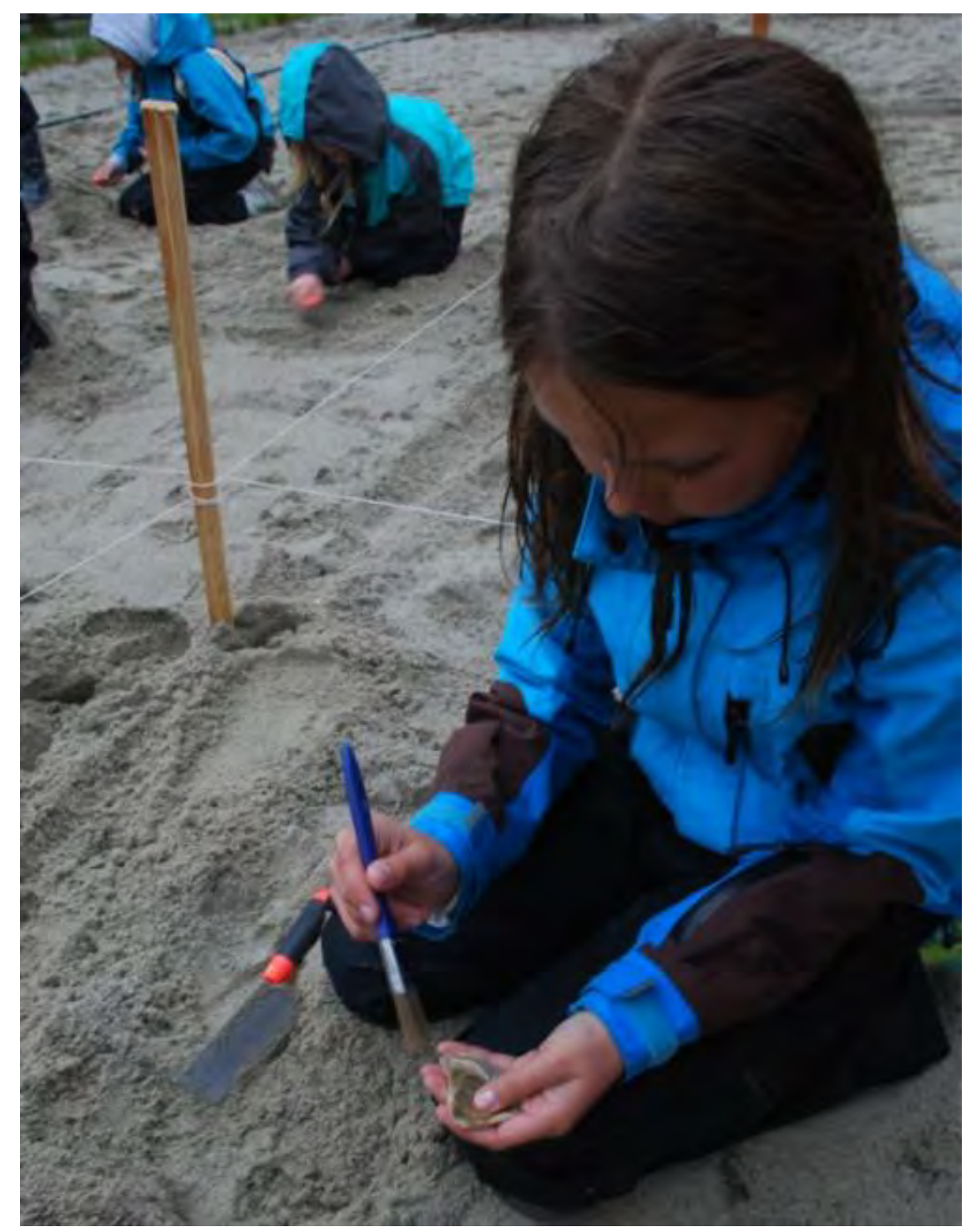

Fotograf: Stein-Roar Slotterøy. 
Bilde 8.10

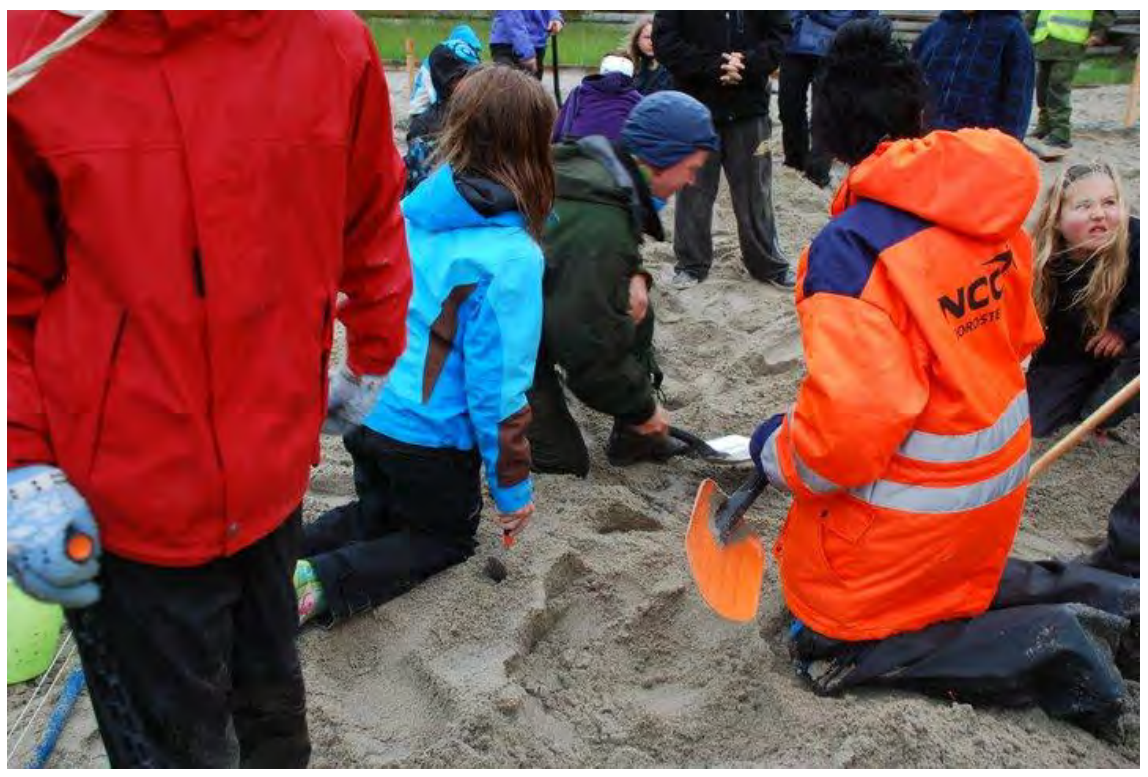

Fotograf: Stein-Roar Slotterøy.

\subsubsection{Læring og glede av naturen}

- Målgruppe: 5.-10. trinn og familier.

- Nøkkeleord: fiske/friluftsliv, mat.

- Kontakt: Friluftsveileder Ingvild Høyland, Norges Jeger- og fiskerforbund, Rogaland, Tel: +47 92649535, Mail: ingvild@njff.org

\section{Beskrivelse av eksemplet}

Formålet med prosjektet er å stimulere barn og unge til økt interesse knyttet til realfag. I tillegg ønsker vi å formidle gleden og nytten av et enkelt friluftsliv, ikke minst fordi erfaringen viser at dersom barn og unge lærer å forvalte naturen, vil de også ha et større ønske om å ta vare på naturområdene. Ved å gi elevene kunnskap om å høste av naturen, kan de utvikle gode holdninger som kan hjelpe til å opprettholde naturen på et bærekraftig nivå også i fremtiden.

Norges Jeger- og fiskeforbund (Njff) ønsker å tilby elever i skolen opplæring i fiske/friluftsliv. Vi stiller med fiskeutstyr til hele klassen, slik at alle har de samme forutsetningene for å få en fin dag ute i fellesskap med klassen. Instruktøren fra Njff vil møte elevene på skolen, slik at elevene skal få opplæring i bruken av fiskeutstyret. Denne undervisningen tar ca. 50 min. og omfatter teori og praktiske øvelser for elevene. Når vi ankommer fiskeplassen til fots (i skolens nærmiljø) monterer alle 
elevene opp fiskeutstyret de får låne hos Njff. Videre vil instruktøren veilede elevene i kasteteknikk og annen praktisk bruk. Det vil bli filetering og dissekering av fisk samtidig som vi gjennomgår fiskens anatomi. I denne forbindelse vil det også bli lagt fokus på menneskekroppens anatomi. Mat er et viktig element i turen, derfor tilbereder vi et varmt og sunt (kanskje fisk fra egen fangst)måltid på bålpanne. Vi ønsker å gi elevene en opplevelsesrik skoledag, som de kan jobbe videre med når de kommer tilbake til skolen, så dvs at vi følger kompetansemålene i kunnskapsløfte når dagen blir planlagt.

\section{Nødvendig materiell}

Fiskestenger, sneller, svivler og fiskesluker. Bålpanne, wokpanne.

\section{Forberedelse og etterbearbejdning}

I skrivet som elevene får med seg hjem, har jeg skrevet at alle bør ha med matboks, slik at vi de kan bruke den som tallerken når vi skal spise. (dette fører til at vi slipper og bruke papp)

Jeg forbereder fiskedagene med at alt utstyret alltid er klart til bruk. Jeg har også satt meg inn i store deler av naturfagspensummet i barnetrinnet, slik at kompetansemålene til en hver tid kan følges.

Den viktigste forberedelsen er å være en god formidler når inne undervisningen foregår.

Eleverne forbereder sig ved at:

- Lese om minst to fisk som finnes der hvor vi skal fiske.

- Lese om fiskens anatomi og gi beskjed om at de skal sammenligne den med mennesket.

- Hvis det er mat og helse som er hovedtemaet, finner elevene oppskrifter som inneholder fisk.

- Fortelle fiskehistorier.

Lærerne kan gi stiloppgave om turen. I naturfag kan de få i opppgave å sette navn på fiskens organer og evt tegne en fisk. Beskrive hvordan vi kan lage en ruse. Gi eksempler på livet rundt et ferskvann eller hva en kan finne i fjæra.

Det er veldig viktig at et en arbeider videre med fiskedagen, dette fordi alle som var med har noe å bidra med, her kan ofte de litt svake elevene bruke sine gode evner på en super måte. 


\section{Om trygghet i gruppen}

- Ved at alle elevene får låne fiskeutstyr, har vi huket vekk dette med hvem som har best utstyr.

- Grundig opplæring i montering, kasteteknikk og andre fisketriks.

- Jeg prøver å se alle elevene der de er.

- Gir positive tilbakemeldinger til hver og en, alle gjør alltid noe bra.

- Veiledning til alle om teknikk, dette gjør at det ikke bare er de som sliter med teknikken som må få hjelp.

- Vi ønsker å formidle gleden og nytten av et enkelt friluftsliv, ikke minst fordi erfaringen viser at dersom barn og unge lærer å forvalte naturen, vil de også ha et større ønske om å ta vare på naturområdene. Ved å gi elevene kunnskap om å høste av naturen, kan de utvikle gode holdninger som kan hjelpe til å opprettholde naturen på et bærekraftig nivå også i fremtiden. Elevene blir kjent $\mathrm{i}$ nærmiljøet og med mulighet til å drive friluftsliv der. Dette kan gi dem en tilhørighet til naturen som kan føre til en sunn, livslang interesse og glede.

\subsubsection{Naturtypekartlegging i sjøen}

- Målgruppe: 7.trinn i grunnskolen.

- Nøkkelord: Snorkling, utfordring for kroppen, feltundersøkelser.

- Kontakt 1: Petter Jørgensen, Feltlærer Kragerø barne- og ungdomsskole, Tel:+47 92255593, Mail:petter.jorgensen@kragero.kommune.no

- Kontakt 2: Per-Erik Schulze, Feltrådgiver marinbiologi Naturvernforbundet, Tel:+47 41856697, Mail:pes@naturvernforbundet.no

\section{Beskrivelse av eksemplet}

At alle elever som er med, uavhengig av tidligere sjøerfaring, gjennom innføring i enkle metoder for marine feltundersøkelser får gjort seg kjent med naturtyper i sjøen i deres nærområde og samtidig får erfaring for videre bruk av snorkleutstyr, våtdrakt og båt til alle årstider.

Alle elever får en halvdags økt med vanntilvenning, og to hele feltdager med kartlegging. På slutten av hver dag leverer elevene egne feltrapporter som også inngår som nyttig i kommunens naturtyperegistrering.

En gruppe med 10-12 elever samles sammen med lærer og feltlærer ved vannkanten eller ved svømmebassenget. Aktiviteten foregår under oppsyn. Elevene skal til enhver tid kunne se veileder, siden veileder da 
kan se dem. Det brukes ikke bly. Dette betyr at elevene har god oppdrift og er trygge.

1. Feltærer viser og beskriver hvordan man tar på en våtdrakt.

2. Feltlærer viser og beskriver hvordan man tar på og bruker dykkermaske.

3. Alle elevene som ønsker det får ta på seg utstyret, og så prøve seg i vannet.

4. Elevene făr vaske og henge opp utstyret, lære vedlikehold.

Våtdrakt er laget av isolerende materiale og vil holde deg varm så du kan være lenge ute i vannet uten å bli farlig nedkjølet. Den er ikke helt vanntett, men har trange mansjetter ved håndledd, ankler og rundt hals. Dermed blir det liten sirkulasjon av vann inn og ut i drakta, og det varmes dermed opp av kroppen din. Dette varme vannet hjelper deg å holde varmen. For at drakta skal fungere godt er det viktig at den passer sånn nogenlunde tett på kroppen, og at du tar den på riktig.

\section{Kommentar/praktiske tips}

Lurt for våtdrakt: Hjelp hverandre to og to! Kan for eksempel hjelpe å ta opp glidelåser, dra av trang drakt. Kan være kjekt å ha en bag å legge dine tørre og varme klær i så du vet hvor de er når du skal opp og skifte og varme deg. Hvis du er ute kan du stå på noe, f.eks. et håndkle, når du skifter. Så blir du ikke skitten og kald, og unngår å trekke med deg granbar og grus inn i våtdrakten.

Lurt for dykkermaske: Skal ikke slenges på bakken, da den etter hvert vil få riper.

\section{Feltdag}

$\AA ̊$ utforske naturen under vann med vannkikkert eller dykkermaske er spennende, og gir i tillegg verdifull informasjon for samfunnet som kan brukes når kommunen skal lage planer for utbygginger og annet. Flere skoler på Sørlandet har jobbet med å kartlegge ålegress og sukkertare i sitt nærområde, og i denne aktiviteten kan du lære hvordan de har gjort det og prøve deg selv som forskerspire. Du lærer samtidig å gjenkjenne, kategorisere og kartfeste naturtyper på grunt vann i sjøen, slik som ålegress, sukkertare, skjellsand eller bløtbunn

I dette undervisningsopplegget kan de største elevene bidra som unge forskere med å kartfeste forekomster av ålegress og andre verdifulle naturtyper på 1-5 meter dyp i skjærgården.

Norge har sammen med de andre landene i verden blitt enige om at de skal kjenne til og ivareta sitt eget biologiske mangfold. Naturtyper er 
særegne og viktige levesteder for artene. Kartfesting av viktige naturtyper sørger for at naturverdier og -mangfold kan bli tatt vare på i forbindelse med utbyggingsprosjekter og forvaltningstiltak.

Direktoratet for naturforvaltning har laget en egen håndbok om viktige naturtyper i sjøen og hvordan de kan kartlegges. Både ålegress, skjellsand, østersplasser, sukkertare og fjærepytter egner seg svært godt for å kartlegges av skoleelever med enkelt feltarbeid.

Grupper på opp til 10-12 elever, med sin faste lærer samt en feltlærer/marinbiolog. Aktiviteten kan med fordel organiseres som et fellesopplegg for flere klasser og skoler ut fra en fast utstyrsbase og ifølge en turkalender.

\section{Bilde 8.11}

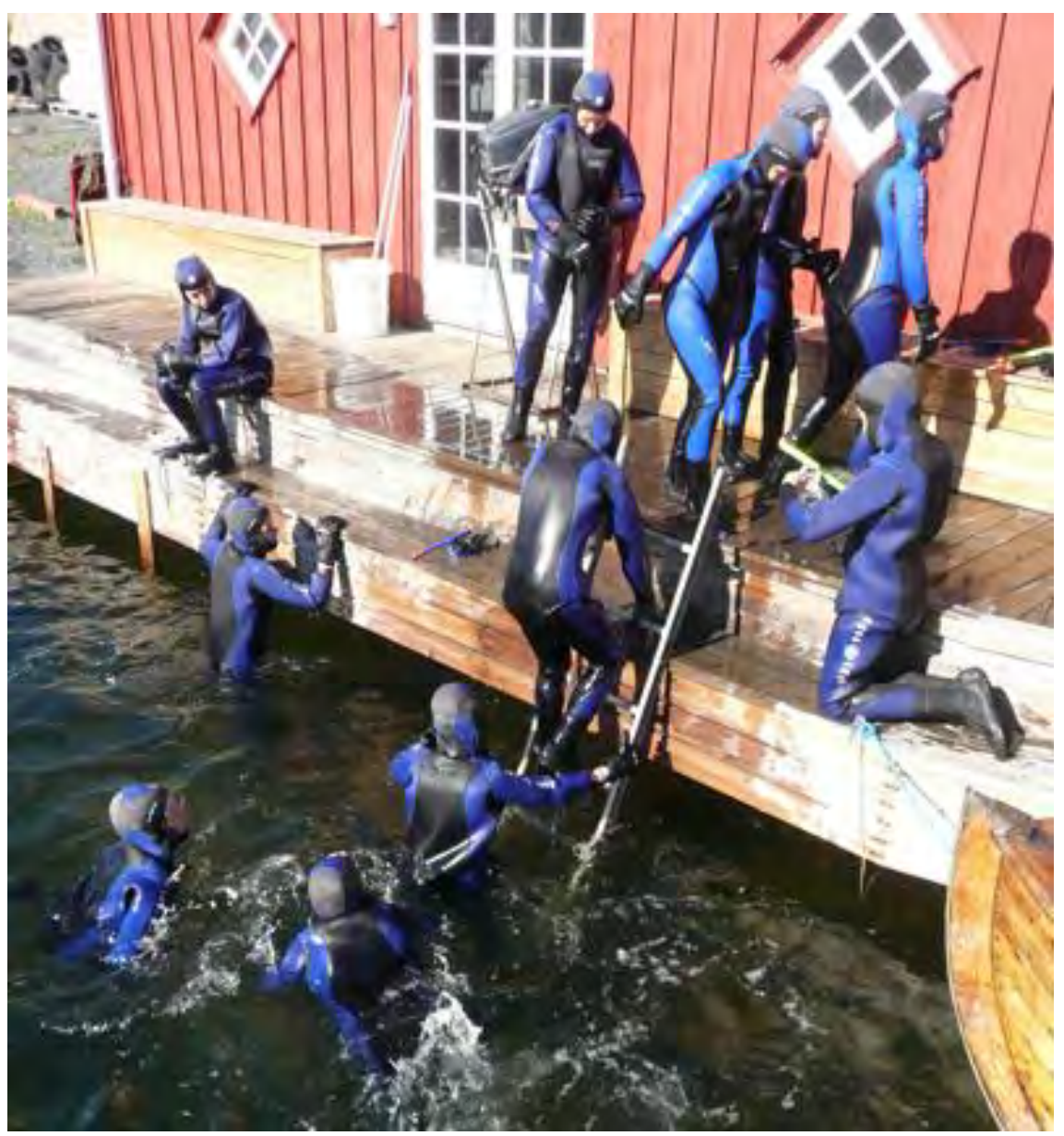

Fotograf: Petter Jørgensen. 
Bilde 8.12

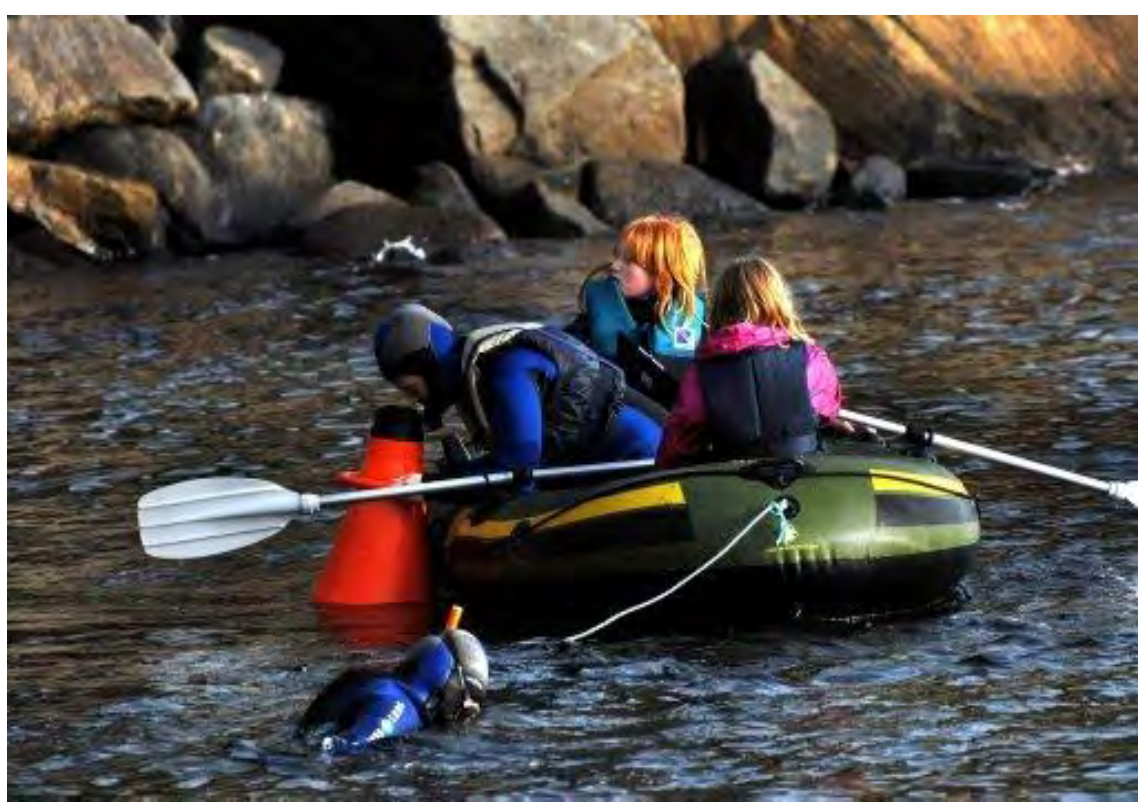

Fotograf: Petter Jørgensen.

Etter nærmere avtale plukkes hver gruppe opp med båt på morgenen ved en brygge i gangavstand fra skolen, eller møter opp direkte på egnet strandlokalitet. Møt opp ved sjøkanten. Ha med godt med varme klær, matpakke og varm drikke. Det er ikke værforbehold, så det er svært viktig å være skikkelig kledd. Kartleggingen vil så foregå i beskyttet farvann i nærheten. Lokalitetene tilpasses vær og vind. Gruppen ankommer tilbake samme sted i god tid for å ta seg hjem før skoledagens slutt.

1. Inndeling i grupper på 2-3 elever. Hver gruppe tildeles en del av sjøen utenfor strandlinjen de får ansvar for å kartlegge (50-100 meter). Hver gruppe får skriveplate, feltregistreringsskjema, og kart over området i målestokk 1:5.000. Kartet skal brukes til å skravere inn og anvise utbredelse av gruppas funn.

2. Gruppene bruker inntil en time på feltregistreringen.

3. Så er det lunsj og skift til varme og tørre klær. Hold dem som fryser i bevegelse. Alle skal pakke sitt eget utstyr.

4. Etter lunsj går man igjennom feltskjemaene i plenum og fyller ut alle rubrikkene, før feltlærer samler inn og godkjenner feltrapportene (skjema og kart). 


\section{Utstyr og forberedelse}

Veileder: sørger for at båt, utstyr, sikkerhet og kjøreplan er i orden, og tilpasser lokalitetsvalg etter værforholdene. Opplegget går hele året uten værforbehold, unntatt når det er is på sjøen.

Aktiviteten kan foregå i beskyttede lokaliteter i skjærgårdsfarvann. Vanndybde 1-5 meter.

På vei til lokaliteten vil man ofte kunne se en del av de aktuelle naturtypene i sjøen, og dermed forberede gruppa på hvordan de ser ut.

Det kan være lurt å samle gruppa inntil en levegg eller lignende.

\section{Råd om utstyr}

Dykkermaske og snorkel. Det er avgjørende for god funksjon at masken passer godt til ansiktsformen, og er helt tett mellom glass og gummi. Altså kreves en viss kvalitet. Vi anbefaler maskesett designet spesielt for ungdom, Midi-størrelse, og av dykkekvalitet. De bør derfor kjøpes fra et dykkerutstyrsfirma eller velassortert sportsutsalg. Billigere masker fra lekebutikk eller sportskjeder vil med få unntak gi brukeren en negativ erfaring med snorkling fordi masken lekker og raskt går i stykker.

Det samme gjelder for våtdrakter. Kun dykkerdrakter er gode nok, ikke billigdrakter som kan kjøpes på Biltema og lignende. Dersom skolen $ø$ nsker å kunne ha lang sesong med snorkling helt ned til 10 grader $\mathrm{i}$ vannet, anbefales vinterdrakter. Hette er viktig.

Feltidentifiseringsplansje laminert med oversikt over naturtypene, lag selv basert på marine håndbøker eller kontakt Naturvernforbundet for et eksemplar av plansje brukt i Kragerø.

Skjema til å notere på i allslags vær lager man av vannfast papir eller plastplater. Bruk blyant.

\section{Forberedelse på skolen}

Lærer og klasse: Får et informasjonsskriv med forslag til forberedelsestema, lenker millimeter i forkant.

Kan f.eks. prate om marine naturtyper og hva som kjennetegner dem. Søk i kartverktøy på nett hvilke naturtyper som er kartfestet i lokalmiljøet allerede. Forberede eget prosjekt. Snakke med elever, foreldre, besteforeldre, lokale fiskere og andre for å skaffe seg et overblikk over hva man vet om hvor disse naturtypene er i distriktet. Snorkeltrening (se egen aktivitet).

\section{Etterbearbejdning}

En mulighet er å skrive opp resultatrapport for klassen og tegne et råkart på papir. Omgjøre dette til elektronisk format, f. eks. pdf eller mer avanserte digitale kart på nettet. Googlemaps eller lignende. Jobbe i 
grupper med å finne mer informasjon om hvilke dyr som bor i de ulike naturtypene, hvilken verdi naturtypene kan ha for mennesker og dyr.

En annen mulighet er å få med en minnebrikke med bilder og filmsnutter tatt under feltdagen, og lage sin egen "forskningsfunn" - presentasjon for You Tube e.l.

\section{Om trygghet i gruppen}

1. Innledende dag med forsiktig vanntrening og gjøre seg kjent med utstyret i skjermete omgivelser (basseng eller rett ved brygga).

2. Samlinger og forklaring fra feltveileder på flere faste punkter $\mathrm{i}$ programmet.

3. Elevene settes sammen i små team, med oppdrag å passe på hverandre akkurat som "dykkerbuddies."

4. Ingen får miste veileder og lærer av syne, eller omvendt.

5. Alle får velge selv om de jobbe fra land, fra båt eller i sjøen, og alle har uansett nyttige roller og er med i gruppa.

Å bygge opp trygghet og mestringsfølelse basert på frivillighet og nysgjerrighet er nøkkelen. Eleverne gjøres istand til å kunne se og observere under vann. Dette er kjernen i aktiviteten. I tillegg spiller kroppens følelse av vektløshet, vann og kulde/varme en viktig rolle.

\section{Om refleksion}

Refleksjon skapes gjennom "Sjokk og begeistring." Denne aktiviteten er så spennende og ny for mange av deltakerne at de ved å være med gjør seg mange refleksjoner. Veileders rolle blir da å være godt tilstede når spørsmålene kommer.

- Snorkling: Hvem har gjort dette før?

- Skjærgården/båt: Er det noen som pleier å være ute i båt på sommeren?

- Kartforståelse: Hvor er vi nå, og hvor skal vi?

- Ålegress: Hva er ålegress og hvorfor er det viktig?

\section{Andre refleksjoner}

Sikkerhet er svært viktig når man har med barn i båt og svømming. Må følge regelverk på dette, og feltlærer og klasselærer må ha den kompetansen som kreves, f.eks. skolenes eget sikkerhetskurs.

Det har fungert svært godt at feltlærer tilbyr klassene en "ferdig pakke." Lærernes egeninvolvering varierer nemlig, men de er uansett svært takknemlige for å stille til dekket bord. 
Opplegget er læring også for lærer og feltveileder. Hver dag byr på et nytt område, nytt vær og nye muligheter til oppdagelser, fremfor å bes $\emptyset$ ke samme sted igjen og igjen.

Tiltro elevene ansvar for feltoppgaver som normalt ville være forbeholdt voksne forskere. De leverer oftest godt.

Jekke ned de strengt faglige ambisjonene og se hvordan elevene blomstrer av begeistring knyttet til sanseopplevelser, og at dette gir direkte utslag i nysgjerrighet, refleksjon og godt skolearbeid.

Faste rammer rundt dagens logistikk gir gode resultater. Dette kommer naturlig når man bruker båt og er på sjøen. Skipper får da en naturlig autoritet, alle er i samme båt, og må følge reglene ombord. Elevene har godt av slike forbilder.

\subsubsection{Undersøkelse av Akerselva}

Følge opp hvordan nærnaturen forandres. Eksempel på hvordan naturforandringer kan følges.

- Målgruppe: 5.-7. klassetrinn, evt. også høyere alderstrinn.

- Nøkkelord: vassdrag, feltundersøkelser, engasjement i lokalsamfunn.

- Kontakt: Kristoffer Øverland, Oslo og Omland Friluftsråd, Tel: +47 22178400,+47 48287887, Mail: krisoof@online.no

\section{Beskrivelse av projektet}

Prosjektet vil søke å synliggjøre sårbarheten til et vassdrag og økosystem ved å gi deltagerne økt naturforståelse og kunnskap. Prosjektet vil skape interesse og kunnskap om bærekraftig utvikling blant deltagerne gjennom at disse aktivt følger rehabiliteringen og de suksessive økologiske forandringene i etterkant av et utslipp av giftige stoffer i elva.

- Utarbeide et prosjekt med høy overføringsverdi til andre deler av landet når lokalsamfunn stilles overfor alvorlige forurensninger i vassdrag.

- Sette fokus på miljømessige (lokale) utfordringer knyttet til Akerselva.

- Stimulere deltagerne til å dokumentere vesentlige sider av natur og kultur som underlag for å verne og vedlikeholde et vassdrag.

- Drive folkeopplysning gjennom mediedekning og annen informasjonsformidling av prosjektet.

- Drive uteundervisning som har faglig forankring i læreplaner. 
Prosjektet er et samarbeid mellom Oslo og Omland Friluftsråd og Oslo Elveforum og ble igangsatt på bakgrunn av et alvorlig klorutslipp i Akerselva, en elv i sentrale deler av Oslo, våren 2011.

Etter klorutslippet ble store deler av det akvatiske livet i elva utradert og det vil være særlig interessant å følge den kommende utviklingen med tanke på biologisk mangfold. Dette motiverer og forplikter skolene til å følge opp arbeidet over flere år.

Hovedprinsippet i prosjektet er at skolene "adopterer" en del av Akerselva med tilhørende forpliktelser.

Skolene vil aktivt drive undersøkelser og oppfølging av den delen av elva de adopterer der forholdet og samspillet mellom de ulike delene av et økosystem vil stå sentralt. Det vil hovedsakelig fokuseres på temaene vannkvalitet, bunndyr og fisk.

Skolene vil også oppfordres til å melde fra om ulovlig forurensning og holde vann og strandkanter fri for søppel.

Dersom det igangsettes fysiske tiltak som eksempelvis laksetrapp, vannkvalitetsforbedrende tiltak og lignende vil det samarbeides med ansvarlige aktører slik at skolene også kan involveres i dette.

Kort om praktisk gjennomføring:

1. Lage samarbeidsavtaler med skoler.

2. Avtale detaljer for prosjektet etter hva som passer den enkelte skole.

3. Lage undervisningsmateriell og fastsette dager med uteundervisning.

4. Gjennomføre uteundervisning.

5. Etterarbeid (skolene/lærerne gjør dette selv).

Naturveiledningen i prosjektet startet 2011 og 2 skoler har deltatt. Naturveiledningen har i 2011 hatt følgende tema:

- Dag 1: uteundervisning, tema vannkvalitet.

- Dag 2: uteundervisning, tema bunndyr og fisk.

- Dag 3: besøk på labratoriet til Vann- og avløpsetaten i Oslo kommune.

Naturveilederen møter skoleklassene ved skolen og har med utstyrspakke med utstyr for dagens tema. Skolene får utstyret etter endt dag slik at de kan jobbe videre.

Prosjektet har store muligheter i forhold til at man kan involvere mange temaer og stor tverrfaglighet. Prosjektet kan også overføres til andre vassdrag, ikke nødvendigvis i forbindelse med forurensning. 


\section{Utstyr}

- Utstyr til måling av vannkvalitet,

- Utstyr til innsamling og studier av bunndyr og fisk,

- Faglitteratur.

Naturveilederen lager utstyrspakker i forkant. F.eks. en pakke med utstyr til måling av vannkvalitet. Det er viktig å legge ved brukerveiledninger til utstyret så skolene/nye lærere kan bruke dette senere.

\section{Forberedelse på skolen}

I forkant av naturveiledningen har elevene blitt presentert for ulike "problemstillinger," f.eks:

- Hvor kommer vannet fra?

- Hvordan renner elven gjennom byen og ut i Oslofjorden?

- Hvorfor er byer som oftest oppstått ved elver, og hva brukte man elven til før?

- Hvordan bør eks elvebredden og kantvegetasjonen være for at dyr, fisk andre organismer skal trives?

\section{Etterbearbejdning}

I samarbeid med lærerne utarbeides det planer for etterarbeid. F.eks:

- Undersøke sammenhengen mellom vannkvalitet og biologisk mangfold.

- Studere variasjon i vannkvalitet og/eller biologisk mangfold gjennom årstidene.

- Sammenlikne resultater med andre vassdrag, andre deler av elva, og andre skoler.

- Studere innsamlet materiale i stereolupe på skolen.

- Delta på fysiske tiltak i Akerselva. F.eks. utsetting av fisk etc.

- Melde fra om mulige forurensninger.

\section{Om å skape eierskap og trygghet i gruppen}

Læreren deler klassen inn i grupper á 5-6 elever. Hvert medlem har sin rolle; materialansvarlig, måleansvarlig osv. Dette stimulerer til godt samarbeid og sikrer at ingen blir tilsidesatt.

Ved å lære grunnleggende økologiske prinsipper vil deltagerne få en høyere naturforståelse. Økt naturforståelse vil føre til at deltagerne eksempelvis vil reflektere over dyrelivet/naturen på hytta, i hagen hjemme, ferier, i de daglige omgivelser millimeter. 
Deltagerne gjøres oppmerksom på at man kan ha naturopplevelser midt i Oslo by. Ved å vandre langs elven "utelukker" man i en viss grad støy og "bylyder."

Som nevnt deles deltagerne i grupper der hvert medlem har et ansvarsområde. Deltagerne må derfor selv bestemme hvorledes de skal løse oppgaven-gjennom aktiv deltagelse.

Deltagerne gjøres oppmerksom på at man kan oppleve et høyt biologisk mangfold i storbyen, men at det er meget sårbart overfor menneskelig påvirkning. Økt naturforståelse $=\varnothing \mathrm{kt} \emptyset \mathrm{nske}$ om vern av naturen .

Deltagerne får også et eierforhold til Akerselva som fører til økt naturengasjement, også vedrørende andre lokaliteter.

Prosjektet har vært vellykket og ble utprøvd med 2 skoler i 2011. Prosjektet vil fortsette våren 2013, da vil flere skoler involveres.

\section{Utfordringer/suksesskriterier}

Man er, i det norske skoleverket, svært avhengig av å fă tak i lærere som er motiverte/interesserte i naturveiledning, og dessuten at naturveiledningen passer i forhold til pensum/ordinær klasseromsundervisning. Dette er en utfordring og krever ofte mye planlegging.

Ved å drive naturveiledning i storbyen må man ta hensyn til trygghet og utfordringer man ikke møter i eks skogen, som f.eks. biltrafikk, hunder og syklende, brukte sprøyter, fremkommelighet millimeter Langs Akerselva er det endel kriminalitet/rusmiljø. Dette er imidlertid klart mest synlig på kveldstid.

1 skoleklasse (ca. 25 elever) per naturveileder har fungert bra. Det er viktig at man inkluderer lærerne ved at disse bistår naturveilederen.

Programmet bør tilpasses noe etter aldersgruppen. Særlig ved måling av vannkvalitet bør dette tas i betraktning og veiledningen forenkles. 


\subsection{Eksempler fra Finland}

\subsubsection{Karin Korsspindel}

- Målgruppe: Barn i åldern 5-12 år.

- Nyckelord: skog, spindler, levevis, ekologi, at jobba undersökande.

- Kontakt: Kvarkens naturskola, Aleksis Hahn, Sandögatan 6, FIN65100 VASA, Tel: +358 40 4199756,

Mail:aleksis.hahn@naturochmiljo.fi

\section{Beskrivning av exemplet}

Spindelprogrammet är ett skogsäventyr tillsammans med Karin Korsspindel. Eleverna får leva sig in i en spindels vardag och får reda på hur spindlarna lever, vad de gör och hur de ser ut. Detta gör vi genom att olika sinnesövningar och lekar som har med spindelns liv att göra.

Programmets syfte är att öppna upp barnens ögonen för det lilla i naturen samt att visa att spindlar också är en viktig del av ekosystemet. Barn är nyfikna och övningar där lek, undersökningar och egna iaktagelser kombineras gör att innehållet blir mera lustfyllt men trots allt mycket faktabaserat.

Tanken är att programmet ska vara ett komplement till undervisningen i klassrummet och bidra till att barnen ska få jobba konkret och undersökande för att lära sig om naturen i naturen. Detta förfaringssätt kan sedan bidra till att ett positivtförhållande skapas till naturen och närmiljön.

Målet med Karin Korsspindelprogrammet är att:

- Eleverna lär sig spindelns grundläggande anatomi och veta skillnaden mellan insekter och spindeldjur.

- Eleverna lär sig om spindlars liv, t.ex. livscykel, jaktbetende, förökning o.s.v.

- Eleverna får positiva upplevelser av spindlar genom egna iaktagelser och undersökningar av riktiga levande spindlar.

- Eleverna lär sig spindelns roll i ekosystemet och enkla näringskedjor där spindeln ingår.

Syftet med och målen i Karin Korsspindelprogrammet är utarbetat så att den också stöder den nationella läroplanen i Finland, Grunderna för läroplanen för den grundläggande utbildningen 2004 (GLGU-04, Utbildningsstyrelsen (hittas bland annat på adressen http://www02.oph.fi/ svenska/ops/grundskola/LPgrundl.pdf). 
Exempel 1. Allmänna direktiv för årskurserna 1-4 i ämnet Miljö-och Naturkunskap. "undervisningen inriktad på erfarenheter och upplevelser utvecklar ett positivt förhållande till natur och miljö hos eleverna." (GLGU-04, s.170)

Exempel 2. Målen för åk 1-4 i ämnet Miljö-och Naturkunskap.

Eleven skall:

- Lära känna naturen och kulturmiljön i den närmaste omgivningen och lära sig att iaktta förändringar i dem och att uppfatta den egna hembygden som en del av Finland och Norden.

- Lära sig skaffa information om natur och miljö genom att iaktta, undersöka och använda olika slags källmaterial.

- Lära sig göra iakttagelser med hjälp av de olika sinnena och enkla verktyg och lära sig att beskriva, jämföra och klassificera observationer.

- Lära sig använda begrepp som används för att beskriva och förklara miljön och därmed sammanhängande fenomen (GLGU-04, s.170).

Exempel 3. Centrala innehållet i åk. 1-4.

- Olika livsmiljöer och organismers anpassning till dem.

- De vanligaste växterna, svamparna och djurarterna i närmiljön.

- Naturen under olika årstider.

- Livsskedena hos växter och djur (GLGU-04, s.171).

\section{Förberedelser}

Rigga upp/knyta ett spindelnät av en flagglina mellan två träd stort nog för att barn ska kunna krypa genom de största hålen (Karins dörr). Markera upp ett lekområde med t.ex. färgade lagband för leken "Vem är rädd för vargspindeln."

\section{Material}

Karin Korsspindel (stor självlagad spindeldocka eller handdocka), flagglina (för välkomstnätet), lagband (märka ut lekområde), laminerade bilder på hjulspindelns nät, skogsmesar och kungsfågeln, luppar och fångstburkar, vita lakan och paraply, insektsugar, finska flaggor, strumpbyxor och suddiga skyddsglasögon.

\section{Inledning}

Naturskolläraren möter barnen strax utanför det egentliga området och hälsar dem välkommna till skogen. Han berättar att Karin väntar på barnen men att vi först måste gå igenom hennes dörr. Naturskola-läraren 
avdramatiserar och förklarar redan nu att Karin bara är en docka och att hon inte är farlig utan bara är ett litet kryp som vill leva, bilda familj och gör allt för att ha det bra i skogen.

Program 1. Välkomnar barnen in i skogen, in genom hennes dörr = spindelnät. Naturskola-läraren riggar upp ett nät (av rep/flagglina) mellan träden. (Äldre barnen kan låtsas vara insekter som försöker ta sig igenom utan att vidröra/fastna i nätet.)

Karin (NS-läraren) berättar lite mera om sig själv och hur hon ser ut.

- Spindlar har en tvådelad kropp, huvud och bakkropp (jämför med insekterna!).

- Korsspindlar har fyra par ögon.

- De har kloliknande käkar som hon hugger sitt byte med och som sprutar in gift i det.

- Pedipalper som hon känner och smakar med.

- Spinnvårtor att spinna nät med som alla spindlar har.

- Fyra par håriga ben som hon också känner med.

- Det korsliknande mönstret på ryggen gör att man känner igen henne.

Alla vet att de flesta spindlar spinner ett spindelnät för att fånga sina byten det vill säga att spindeln är ett rovdjur. Det är oftast insekter som flyger in i nätet och fastnar på den klibbiga tråden som de spunnit från spinnvårtorna bak på kroppen. Karin är en korsspindel och spinner hjulformade nät (familjen hjulspindlar).

Program 2. Barnen delas in i smågrupper om två och två. Varje grupp får i uppgift att tillverka ett spindelnät av pinnar eller grässtrån på ett sittunderlag. Det ska likna en korspindels hjulformade nätkonstruktion som läraren visar med hjälp av en bild.

...och 3. Grupperna får dessutom tillverka sin egen spindel av naturmaterial. Använd kottar/svampar/löv som kroppar och pinnar, barr, bär, stenar o.s.v. till övriga delar av kroppen.

Karin berättar vidare att alla spindlar inte fångar sin mat med hjälp av nät. T.ex. vargspindeln och hoppspindeln springer i kapp eller väntar in sitt byte och överfaller det med ett språng/hopp. De har ögon som ser väldigt bra också byten som står helt stilla.

Program 3. Lek: "Vem är rädd för vargspindeln?" En är vargspindeln och de övriga är insekter. Alla barnen ska ta sig från en baslinje över till andra sidan utan att bli fast av vargspindeln. Vargspindeln gömmer sig $\mathrm{i}$ terrängen bakom ett träd, sten eller buske och "attackerar" då en insekt kommer tillräckligt nära. Den som blir fasttagen blir sedan också en vargspindel. Barnen vid baslinjen får inte titta var spindlarna gömmer 
sig utan måste vända bort blicken och en ur personalen säger när man får svänga sig om. Den ropar sedan också ut "Vem är rädd för vargspindeln?" o.s.v.

Program 4. Hoppspindeln kan hoppa 10x gånger sin egen längd! Vi provar alla att hoppa längd. Hur långt kan vi hoppa från jämfota? Hur långt skulle det bli om vi kunde hoppa 10x vår egen längd? Vi provar och mäter!

Men korspindlar och de flesta andra spindlar ser väldigt dåligt och otydligt. De kan endast se skuggor och reagerar bara på rörelser.

Program 5. Lek: Spegeln. Med specialtillverkade "spindelglasögon." Tillverkas av två stycken luppar som linser och gummiband så att eleven som är "spegeln" endast ser suddigt, som korsspindlarna gör. Spindlar hör ej heller något varför spegeln har öronproppar i öronen (De flesta spindlar ser dåligt och reagera enbart på rörelser och skuggor) Spegelleken går till så att ett barn ställer sig t.ex. vid ett träd vänd med ryggen mot de övriga barnen som står ca. femton meter ifrån på en baslinje. Barnens mål är att försöka smyga fram till "spegeln" utan att den ser någon röra på sig. Spegeln får när som hellst svänga på sig försöka upptäcka rörelse från de andra barnen, men måste vända ryggen till med jämna mellanrum för att ge de smygande barnen en chans att nå spegeln. Ifall spegeln upptäcker rörelse från något barn pekar den mot barnet och då måste den börja om från baslinjen. Det barn som först når fram till spegeln får vara spegel nästa gång.

Karin fortsätter och berättar att fast spindlar är rovdjur så blir också de jagade av andra. Vem är det som äter spindlar? (Småfåglar/mesar, ödlor, grodor t.ex.).

Program 6. Lek: Kungsfågeln och spindlarna. En är kungsfågel och går längs en stig ca. 20-30 meter. (jagar spindlar längs en grankvist). Spindlarna gömmer sig ute bland "småkvistarna" på grenen, d.v.s. så nära stigen att de kan se till stigen hela tiden. Kungsfågeln måste med hjälp av sin syn hitta sitt byte och enbart genom att titta runt omkring sig då hon går längs stigen. Hittar hon en spindel ropar hon namnet på den hon ser och som då måste komma fram till stigen och blir "kungsfågelmat."

Karin berättar vidare att korspindlar kan lägga 300-400 ägg under sensommaren och på hösten. De gömmer äggen t.ex. under en skyddande bit av bark på ett träd eller i ett skrymsle på en husvägg. De spinner tråd ovanpå äggen så att de skyddas ännu mera. Korspindlar kan lägga flera äggkokonger och lämnar dessa vind för våg. Då vintern kommer dör de vuxna spindlarna av kölden. Ungarna kläcks sedan på våren.

Program 8. Lek: Spindlar under alla årstider. Vi rör oss först långsamt och "smått" (små nykläckta spindlar på våren). På sommaren rör vi på oss mera raskt och spinner egna fina spindelnät (fullvuxna). På hösten 
igen rör vi på oss långsammare (det börjar bli kyligare). På hösten lägger vi även ägg och spinner in dessa i en varm "filt" och vaktar våra ägg. Då vintern kommer kurar vi ihop oss i ett litet krypin.

Program 9. Aktivitet: söka spindlar/insekter och spindelnät. Anv. paraply, vita lakan, insektsugar och luppar. Vi undersöker och försöker hitta spindelns alla delar som vi pratat om tidigare. Samtidigt försöker vi hitta hjulformade nät som kunde vara Karin korsspindels kusiners nät. OBS! Var försiktiga med spindlarna och näten. (Alla kan, om tid lämnar över, hitta ett kryp in åt Karin var hon kunde lägga sina ägg för vintern. En skyddad lite plats i en springa i barken på ett träd eller dylikt. Märka ut den med flagga och göra det mysigt och hemtrevligt.).

"Imse Vimse spindel klättra upp för trånn.

Ner faller regnet spola spindeln bort

Upp stiger solen torka bort allt regn.

Imse Vimse spindel klättra upp igen."

Extra: Program E1. Stafett: Fyra barn i grupp som håller i varann och ska springa tillsammans en bana. Benen ska samarbeta precis som spindeln klara av att gå med sina åtta ben.

Program E2. Träna på att bära ägg som vargspindeln gör. Ha en/flera kottar underhakan som ska transporteras en viss sträcka. Detta kan man också göra till en stafett om man vill. (Vargspindlen bär sina ägg i en kokong fäst på bakkroppen.)

Program E3. Spindelnätkonst: Ifall det är blött ute och det finns dagg på spindelnäten kan man med gruppen göra spindelnätkonst. Du behöver en bit paff, mjöl, sil, fixspary. Ta din bit paff och tryck den försiktigt mot ett vått spindelnät. Du får ett vått mönster på din paffbit. Häll sedan mjölet genom silen på din paffbit med mönstret på. Blåsförsiktigt bort överloppsmjöl som inte fastnat i det blöta spindelnätsmönstret. Avsluta med att spraya fixspary över ditt konstverk.

\section{Efterbearbejdning}

Man kan jobba med spindlar i ämnet bildkonst och småslöjd genom att tillverka egna fina spindelnät och spindlar av olika slag och med olika tekniker.

De äldre barnen kan jobba och forska mera om spindlar så att de lär sig ännu mera och redovisa på olika sätt. Powerpoint, collage o.s.v.

Skaffa ett terrarium och "plantera in" en spindelart som man fångat själv och följa med hur den beter sig. Se hur den bygger fångstnät. Följa med och se hur den fångar sitt byte. Hur den gör sen då bytet fastnat osv. Det är lätt att även hitta spindelnät i naturen och aktivt följa med hur spindeln beter sig. 


\section{Naturvejlederens egne refleksioner}

- Jag har alltid tydliga rutiner! För att avbryta en programpunkt eller för att fånga allas uppmärksamhet visslar jag i en speciell visselpippa som låter som talgoxe = samling.

- Alltid då vi samlas så bildar vi en ring och alla står fot mot fot = alla är med, ser och hör allt jag säger och gör.

- Inget barn tvingas att delta i någon av programpunkterna men uppmuntras vänligt.

- Viktigt är att läraren är entusiastik och själv intresserad av temat då ryks barnen med och deltar i allt "automatiskt."

- Visa gott exempel själv!

- Hjälpa och stöda speciellt de barn som har obehag för spindlar.

- Lyssna på varje barn och visa respekt men var trots allt en tydlig ledare.

- Om du inte känner gruppen från tidigare låt den egna läraren dela in i mindre grupper då det behövs. Han vet vem som kan jobba tillsammans och vem inte alls går ihop o.s.v.

\section{Om refleksion}

Efter varje lek eller övning håller jag ett kort reflektionstillfälle genom att samla gruppen och ställa någon kort konkret fråga. Jag ger även eleverna möjlighet att fråga mig om det finns något de undrar.

Några av övningarna/lekarna kräver mer eller mindre problemlösning och då ställer jag ofta lite ledande frågor beroende på ålder för att de ska komma till rimliga lösningar. Ibland kan jag även låta någon elev komma fram och visa för de övriga vad den har kommit på o.s.v.

I slutet av programmet håller jag alltid en sammanfattande diskussion/frågestund för att se vad barnen lärt sig under programmet.

\section{Om brug af sanser}

Av våra sinnen används specifikt endast syn och känslesinnet i de olika övningarna eftersom det är främst dessa sinnen som är mest relevanta för spindlar (dålig syn, mycket god känsel). Barnen får trots allt jobba med hela kroppen nästan hela tiden. De ställs också inför probelm och måste lösa dem. Det finns moment av spänning vilket gör att programmet det blir roligt och lustfyllt.

Alla övningar förutom den inledande "berättar stunden" (spindelfakta som Karin berättar) är aktiviteter där eleverna är aktiva på något sätt.

Problemlösning krävs framförallt vid tillverkning av egna spindelnät av naturmaterial och hoppspindelövningen. Ifall man vill kan man även 
låta eleverna söka sina spindlar själva först vilket kräver problemlösning för att hitta dessa. Var finns det spindlar? Var kan man hitta dessa lättast?

Genom att dämpa obehaget för spindlar samt att förklara för barnen spindlarnas viktiga uppgift i ekosystemet kan man få dessa barn att förstå en del av hur "allt hänger ihop." Man kan ta upp och diskutera enkla näringskedjor där spindlar ingår för de äldre barnen för att visa på detta. Genom kunskap och egna erfarenheter får barnen en egen uppfattning som jag tror säkert bidrar till en medvetenhet för den naturliga miljön. Då barnen "lär känna" något i naturen som lever bildas det även empati för detta levande. Försvinner sedan livsmiljöer och/eller dessa arter som man lärt känna så vill man värna om dessa.

Det är viktigt att vara en tydlig ledare/lärare som håller i trådarna med en fast hand men med glimten i ögat. Visa respekt, var rättvis, lyssna på barnen men sätt också gränser och ge konsekvenser för fel beteende. Det vitigaste är dock att var entusiastisk och genuint intresserad av spindlar då går oftast allt som planerat.

\subsubsection{Looking for the Old-Growth Forest}

The program has very clear idea of phases needed in every program: Introduction, inspiring enthusiasm, focusing attention, direct experience, shared enthusiasm. Many actions can be settled in one program if it is well planned.

- Target group: School classes grade 5-6 (11-13 year olds).

- Key words: Old forest, species of forest, ownership, hands in the ground, different styles of learning.

- Contact: Elina Pilke, Metsähallitus, Natural Heritage Services, Southern Finland/Nature Centre Haltia www.haltia.com, www.outdoors.fi, Kattilantie 33, 21280 ESPOO, FINLAND, Tel:+358 40581 3534, Mail:elina.pilke@metsa.fi

\section{Description of the example}

After the excursion, the students will have an understanding of the features of an old-growth forest, the scarceness of this forest type and the reasons that old-growth forest species are endangered.

- Students learn to study nature outdoors (national curriculum objective).

- Students learn to understand how old-growth forest species have adapted to their living environment (national curriculum objective).

- Students can describe the key features of an old-growth forest. 
- Students understand the scarceness of old-growth forests and the resulting endangered status of species.

The program takes 3 hours.

In the introductory part, the participants are welcomed to the national park, the rules are explained briefly and old-growth forests are described shortly.

In the action part, the participants familiarize themselves with the features of an old-growth forest through activities and personal exploration.

\section{Introduction}

On this excursion, you must remember the following rules:

- The guide is the one who knows where you are going. In other words, the guide always walks first.

- If you can be quiet, you will see and hear more.

- When you hear the call of a tawny owl, or when I blow on this whistle, everybody must gather around me.

- Picking plants and disturbing nature in any way is not allowed in the national park. You can only collect loose objects. Picking berries and fungi is allowed, however, unless we are in a strictly protected area.

The theme of this excursion is nature study and old-growth forests. You can see if you have what it takes to become a natural scientist. Together, we will determine if the area we are studying is a valuable and rare oldgrowth forest or the more common commercial forest.

The programme starts with a food chain game. In this game, some of the students are beard lichen, that is stuff hanging off the trees that looks like a beard. The beard lichens declined sharply twenty or thirty years ago, but now, thanks to measures to prevent pollution, they are on the increase again. Beard lichen is food for the dotted carpet moth, which is endangered in some areas. Dotted carpet moths, in turn, are food for the northern bat. The northern bat is a species that lives further north than any other bats. The northern bat needs hollow trees for its daytime hideouts.

\section{Food chain game (15 min.)}

A clothes peg each is needed for the players. The pegs represent plants (green), herbivores (blue) and carnivores (yellow). The plants are lichen, the herbivores are dotted carpet moths and the carnivores are northern bats. The number of plants is the highest, the number of herbivores the second highest and the number of carnivores the lowest - as it is in the 
wild. Before playing the game, the participants discuss food chains in nature. They should also consider which group humans belong to.

At the beginning of the game, everybody gets one peg. The animals close their eyes, while the plants take off and hide somewhere, as plants take root rather than run. After a while, the leader sends the herbivores out. They eat the plants by snatching up their pegs. Soon after the herbivores, the predators set out. They catch the herbivores and take their pegs. The last one to go out is the lumberjack, who cuts down the forest, or fells the nesting trees and tries to catch anybody at all. The game ends when everybody has been eaten, or when the lumberjack can no longer run. The players have to hand over their pegs voluntarily.

Variation 1: The game also includes decomposers that catch the carnivores, or anyone else.

\section{Focusing attention}

Old-growth forest Kim (15 min.).

The leader takes out distinctive features indicating that the forest is an old-growth forest, which he/she has collected in advance (e.g. a tree fungus, rot wood, cones, leaves and branches, etc., of various tree species, creepy-crawlies, a feather, flying squirrel droppings, etc. No more than 10 things should be used), and they are set out so that everybody can see them. The group is told that they can look at the objects for one min., then they have to remember what they saw. Everybody is asked to turn their backs, and one object is removed. The group turns around and tries to discover what is missing. Once the missing object has been discovered, the group is told why it is an indication of an old-growth forest. The game continues until all of the objects have been discussed.

When the objects are introduced to the group, the following features of an old-growth forest are discussed:

- Old trees, aged over 100 years

- Young trees in small clearings where trees have fallen over because of old age, a storm or a disease.

- Many different tree species.

- Rotten trees, old rotten hardwoods that are particularly valuable.

- Tree fungi as decomposers.

- Trees with hollows > woodpeckers make a new hole for themselves every year, thus building homes for many other species. 


\section{Research questions (20 min.)}

The students are asked to divide themselves into five groups, with an equal number of members in each group. The groups make up questions (2-3 questions/group); the answers to the questions will help the groups determine if the environment surrounding them is a valuable old-growth forest. The groups take turns reading out their questions. The participants work together to select the questions they consider the most important. Alone or in groups, the participants think about how they could find answers to their questions; in other words, a research plan is produced.

Key questions should take into account:

- Age.

- Number of tree species.

- Amount of rotten wood.

- The inhabitants of an old-growth forest.

\section{Direct experience}

- Tree species (15 min).

To start off with, the students should be taught that the most important tool for identifying trees is your neck. When you use your neck to tilt your head back, you can see the top of the tree, making it easier to identify the tree. If you only look at the tree trunk at eye level, it is difficult to tell one species of tree from another.

Tree species can also be studied by handing out tree species cards to groups of 2 to 3 persons. Each group finds the species on their card in the surrounding area and, finally, the groups take turns introducing the species to the others. The identifying features of the tree species in question are also discussed.

- Age of trees (15 min.).

The students study the age of an old, large tree that has been marked in advance (the same tree each time) using a bore to obtain a core sample, from which they can count the growth rings. The students that are willing to do so are allowed to operate the bore for half a turn or so. Instructions for using the bore are attached.

The students study the age of the younger trees. If there are young pine trees in the area, the students can work out their ages in the small groups that were formed earlier by counting the number of branch whorls. 
A spruce produces whorls, too, but it can grow several smaller and more fragile branches in between the whorls in the same year, which should not be counted. Unlike the spruce, the age of a birch or other hardwood trees cannot be estimated even roughly by looking at the branches.

- Hunting for species (30 min.).

When the students have studied the tree species and their ages in the forest together, they divide themselves into the five small groups that were formed earlier. The groups are handed the equipment and given their instructions. Each small group is also given the work instructions for their group in writing. Each group hunts for species so as to find out what organisms live in the area.

The guide joins the group hunting for creepy-crawlies. It is a good idea to send any other adults out with the remaining small groups. The more restless students can be picked for the groups focusing on creepycrawlies, tree fungi and animals, while plants and rotten trees are suitable for more quiet groups.

The small group members should prepare to act as experts for their own species hunt and to present their findings to the other groups.

- Hunting for species in groups.

Creepy-crawlies: The students check the jar traps and look under the corrugated cardboard on trunks. The creepy-crawlies are gently moved into sample jars while still alive. A piece of fabric is used to identify a couple of species.

Tree fungi: The group looks for any tree fungi occurring in the area. Tree fungi cards are used to identify a species. The cards for those tree fungi that were found in the forest are hung on a display string.

Animals: The group looks for traces and droppings of animals occurring in the area. They use trace cards to identify the species. The cards for those traces that were found in the forest are hung on a display string.

Plants: The group studies plants in a square metre plot 1 meter * 1 meter) marked in advance and uses plant cards to identify the species in it. The cards for the plants that have been identified are hung on a display string.

Rotten trees and dead standing pines: The group looks for rotten trees and dead standing pines. When they find one, they determine the tree species and the degree of rotting. A screwdriver is used to determine the degree of rotting in trees lying on the ground. A table of rotten trees is attached to a display string. 
- Old-growth forest or a commercial forest (15 min.).

Form the specialist groups, which contains one member of each species hunting group. Every member presents the findings of their species hunt group (working scheme and found species). After this all gather still together around the display strings and present findings all together.

The display string of the forest the students have been studying is compared with a ready-made string for reference forests, which the guide has displayed (the average 80-years old commercial forest from southern Finland). The students discuss the status of the forest, and they can vote on it if necessary: an old-growth forest or a common commercial forest? The guide briefly explains how few old-growth forests there are, the reasons why old-growth forest species are endangered and the differences in biodiversity between natural and commercial forests.

At the end, the creepy-crawlies that were caught are gently released back into the wild.

\section{Shared enthusiasm}

- Cornell's tree speech (10 min.).

The participants are asked to find a comfortable place where they can stand, for example leaning on a tree trunk. They are told to close their eyes and follow the instructions, imagining that they are trees.

"Trees are very important for life on Earth. They produce a major part of the oxygen in the world. They hold soil in place, preventing erosion. They give food and shelter to countless animals. In the winter, they warm up the area surrounding them, and in the summer, they cool it down with their shade."

Close your eyes and imagine that you are walking in an old-growth forest with large trees (a pause). You have just arrived at the heart of the forest. Stop and feel yourself becoming one of the valuable giant aspens in the forest.

Stand firmly with your feet slightly apart and feel how your root system starts to grow down from your shoulders. Feel how it grows further and further down through your sides, your knees, your ankles, your heels, deep into the ground beneath you. Your tap root goes down through the humus, sand and gravel, firmly digging its way through the ground (pause).

You now start growing side roots in all directions underneath you, just under the surface of the ground. You grow them to the left and right, 
behind you and in front of you. Send your roots out several metres in front of your trunk (pause).

Lightly sway back and forth. Feel how firmly you have taken root in the soil (pause). In your mind's eye, look at your strong trunk and see how big and tall you are (pause). Is your bark smooth or rough? Is it dark or light? Does it shelter insects (pause)?

Now follow your trunk up and up until you reach your largest boughs. Follow one of them and see how it divides into ever smaller branches that reach to the blue of the sky. What kind of leaves do you have? Are they already big, fluttering in the wind? Has a flying squirrel been nibbling at them?

Absorb energy from the warm rays of the sun. Take it into your leaves and turn it into nutrition using sunlight, air and water that you have brought up from the ground through your roots. Spread the nutrition down from the leaves, all the way to your roots. Store it there. Spring is the time for growth, summer the time for storing nutrition.

Feel how moisture rises from your root hairs and the roots to the trunk, the branches, the leaves - first in small rivulets, then in larger flows, until finally it evaporates through the leaves, moistening the surrounding air and the entire atmosphere...

Sense your uniqueness. You are a magnificent aspen, a key species in an old-growth forest. 120 different species depend on your existence. "During the 200 years of your life, hundreds of bird broods and mammal litters, from flying squirrels to willow tits, may be born in the hollows made by a great spotted woodpecker."

- What can I do? (20 min.).

Discuss with the group what kind of values you can find in natural or alike old forests, and what kind of values do the commercial forests have.

Students think together about what each of us can do to save oldgrowth forests. For example less paper means more forest. Each participant thinks of a promise and whispers it to a tree selected by him/her.

Give every student a card, which is same size than a credit card. Tell that a credit card is a card which you can have credit with, but you must pay back later. The card which students got is the credit card of the nature. Every of us borrow from nature every day, but we must pay back what we borrow. Everyone can glue a little piece of nature to his/her card and write, how he/she will pay the loan back (an own promise, what will he/she do for nature/forests). 
When the cards are ready, come together in circle and listen to this Beside the fire (the song of Gandalf the Grey) (words by J.R.R. Tolkien, The lord of the rings).

I sit beside the fire and think

of all that I have seen,

of gold meadow-flowers and butterflies

In summers that had been;

of yellow leaves and shining gossamer

In autumns that there were,

with morning mist and silver sun

And cool wind upon my hair.

I sit beside the fire and think

of how the world would be

When winter comes without any spring

For still there are so many many things

That I have never seen

In every wood clearing in every new spring

There are so many different kind of green,

I sit beside the fire and think

of people long ago,

And people who will see the a world

That maybe I shall never know

But all the while I sit and think

of times there were before,

I listen for returning feet

And voices at my door 
Figure 8.13

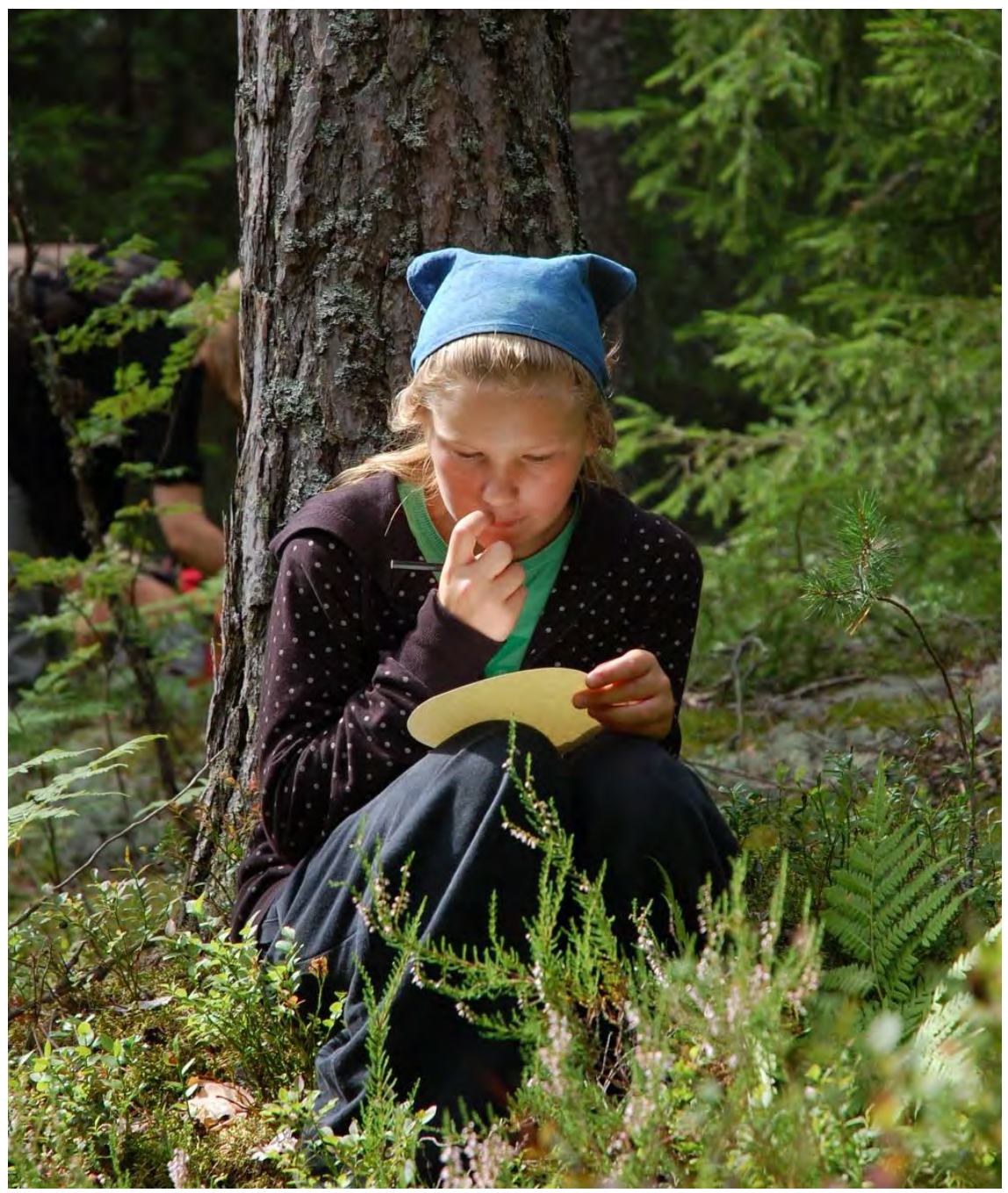

Fotograf: Elina Pilke.

\section{Equipment and materials}

In a rucksack: first aid kit, spare clothes (jumper, hat, raincoats), tawny owl whistle, a bag full of pegs in different colours, objects needed for the Kim game + piece of fabric, tree species cards, bore, laminated work instructions, sheet for identifying creepy-crawlies, trace cards, tree fungus cards, plant cards, string and pegs, screwdrivers, rotten tree table and a transparency marker, species cards for the reference forest, laminated tree speech in the forest: jars for creepy-crawlies, corrugated cardboard traps, a rope for marking the study area for plants. 
Outside The day before, attach two strips of corrugated cardboard to the research area on selected trees. Wrap the cardboard around the tree with the ridges facing the trunk, and attach them with string. For trapping the creepy-crawlies, dig a few jars into the ground so that their mouths are level with the surface of the ground. Set up a rope delimiting the study area for plants in the ground (approx. 1 meter * 1 meter).

\section{The group's preparation}

The group is sent an advance task and instructions for preparing for the excursion to the national park.

Advance task: Tree species memory game.

In groups of 4, the students make a tree species memory game either by collecting leaves outside or by using images found at the Metsä oppimispolku website:

http://www.oppimispolku.fi/metsa_suomi/polku.nsf/liitteetbyid/D4 1DEF52CA5EF0F7C2256EA900298D05/\$file/Puulajit_FI_bw.pdf.

The memory game should contain the following species: spruce, pine, birch (downy/silver birch), ash, rowan, alder (grey alder/common alder) maple, lime, goat willow and willow. The students play the memory game in groups of 4 .

They can also use the Tunnistatko suomalaisia puita (Do you know the Finnish trees) quiz, which can be found online at: http://www. tkukoulu.fi/ mmaalto/puita/puut.htm

The instructions for the advance task are sent to the school together with a confirmation of the reservation.

\section{Working after the visit}

A photo story of the excursion can be produced. The students can complete a comparison study in a forest near their school. They can think of practices that save trees and tell others about them, for example in a school magazine, in an event, or in letters to the editor.

\section{On feeling secure in the group on about the activity}

The guide is calm and reliable. In the beginning, the rules of the excursion are explained, at which point it becomes clear that the guide is very familiar with the area. Everybody follows the shared rules.

During the programme, the participants complete the tasks together within clearly defined, limited areas. Instructions are given clearly, and the guide makes sure that everybody understands them. 


\section{On reflection}

The programme has a section where key research questions are considered in a group. This is part of the Kim game, which includes a section on reflecting upon what has been learned. After hunting for the species, the results are collected on a string, they are examined together and they are compared to a reference forest. In this connection, the group discusses the observations, and the participants formulate a shared opinion on the results of the study. At the end of the programme, all participants consider what they would personally be prepared and willing to do to preserve old-growth forests.

\section{On involving all the senses in the activities}

In the exercises included in the programme, the senses of sight and hearing are needed above all. The sense of touch is also involved in identifying tree species.

\section{On involvement}

In particular, drawing up research questions and the comparisons made after hunting for the species require problem-solving skills. All exercises require active participation.

The programme gives young people knowledge about biodiversity, especially regarding old-growth forests. Towards the end of the programme, they consider means for protecting old-growth forests, and every participant gives his/her personal promise on this theme.

When the programme was created, its maximum duration was set at 2 hours. If the programme is extended to last an entire day at the nature school, exerting an influence in society can be introduced as a part of the actual programme, for example by writing letters to the editor, online articles, etc. In a two-hour programme, this section is left as an exercise to be completed afterwards at school.

If possible, the students should examine two different types of forest: one with a commercial forest structure and another with features of an old-growth forest. If there is enough time, expert groups (new groups consisting of one representative from each group that hunted for a species) would be a suitable way of sharing the results with all groups.

It is important to include the perspective of exerting an influence, if the group has enough time. 


\subsubsection{Mobile Learning Environments (The Mobiilisti maailmaan) project}

- Targetgroups: Basic education students in classes 5 to 9 (aged 10-15 years). Depending on the ICT skills of the group, even younger learners are welcome to take part in testing the model.

- Keywords: Mobile technology in Nature Interpretation, exploratory and participatory learning, flexible learning sites.

- Contact: City of Helsinki, Media Centre, Juhani Kärki, Mäkelänkatu 84, 00610 Helsinki, Tel: 09-31086988, Mail:juhani.karki@hel.fi, mobiilisti.maailmaan@gmail.com, https://sites.google.com/site/mobiilistim/

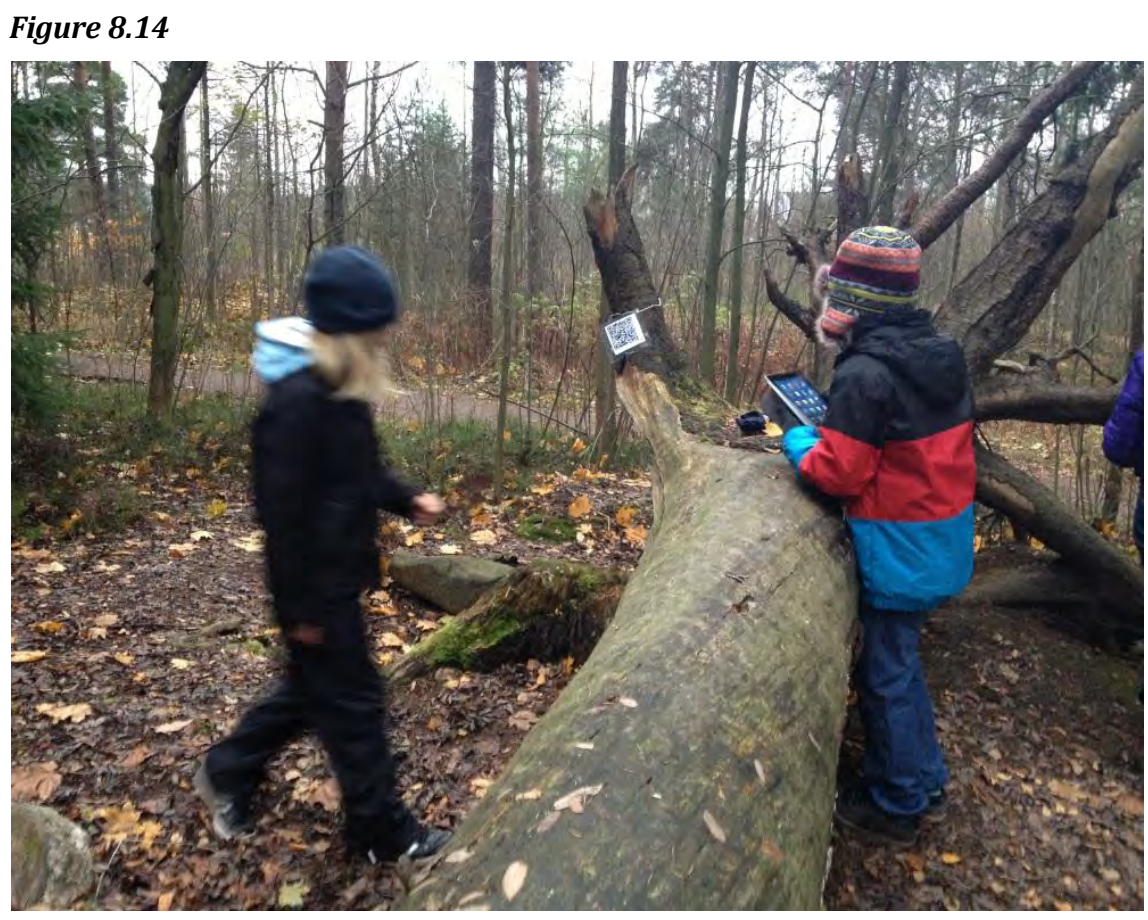

Photographer: Juhani Kärki.

\section{Description of the example}

The objective of the project is to create new practices for promoting exploratory and participatory learning on study excursions based on the use of tablet computers and geographical information. At the same time, new ways of making every day learning environments part of school education using mobile devices and online environments will be developed.

The goal of the operating model to be developed as part of the project is to lower the threshold for using learning environments outside the school 
in school education, to develop the pedagogical quality of study excursions and to create continuums and seamless transitions between everyday learning environments, virtual environments and work in the classroom.

The project aims to focus attention on interactive relations in learning situations, the students' personal sense-making processes and operating practices that reinforce the students' role as actors/subjects. The project will also test how ICT and online environments can offer communal and dialogical working methods as well as simplify and make more efficient the acquisition, documentation and analysis of information. The project also seeks more in-depth answers to the questions of how learning situations could be made into comprehensive and experiencebased sense-making events, and why it currently is not very common for schools to go out to everyday environments.

Under the national curriculum, teaching may be divided into subjects or it may be integrated. The Mobile Learning Environments project seeks to integrate the stated objectives of various theme areas as a part of studying. Humans and technology, responsibility for the environment and growing as a human being are theme areas that are relevant to the development of the operating model for exploratory learning and participatory pedagogy. The pedagogical possibilities of exploratory learning are also reflected in other curriculum-based study, depending on the theme that the students are focusing on at any one time.

During the process of exploratory learning, the main point is not always the end result but the journey the students complete to get to the result, in other words, the process. There may thus be great variations in the end results depending on the project.

Example 1. The group goes to Suomenlinna to study the environment of the island. As a form of debriefing, each participant uses a social media map application to create a game for the others in which the players have to identify plants. Each group member plays at least one game. (sovellusesimerkki: Grafetee).

Example 2. The groups examine the unique nature of Viikki at the Töyhtöhyyppä Nature School. They collect information and observations and take pictures related to a selected theme. The group uses a tablet device to create a pdf book on the theme and distributes it to the others for reading and commenting. (sovellusesimerkki: Creative Book Builder, iBooks Author).

Example 3. At the Heureka Science Centre, the groups are given the assignment of studying a certain phenomenon that they need to learn about. Each group brings with them media devices. They take pictures, shoot videos and make recordings of their interviews with experts. The 
groups use a tablet device to create a video with the material they recorded at Heureka, and at the end of the project, the groups watch the videos together. (sovellusesimerkki: iMovie).

\section{The Nature Interpreters preparations}

The group leader must specify the frame of reference of the study area in advance. What is the frame of reference - or theme area - of the studies? The group leader decides where the study will be carried out and makes arrangements for any reservations, meals and travel expenses that are required. He/she must also check that the media devices are working, that the batteries are fully charged and that the required software has been downloaded onto the tablet devices.

\section{Preparation before and after in the schoolclass}

The group should be informed well in advance of the theme area assigned to them so that each member can prepare and collect information ahead of time, should they wish to do so. Depending on the nature of the destination, the research problems may sometimes only be selected after arriving there. It should be noted that it is difficult for learners to find something that would interest them in an unfamiliar environment before the visit. In that case, it is a good idea to allow the learners to familiarise themselves for a while with the environment to be studied, for example by completing preliminary tasks or by exploring the environment for a while.

Depending on the duration of the project, the students can work on the material after the excursion. If the research project only lasts for one day and the aim is to turn out the finished product on the same day, it is not necessary to continue working on the subject. The processes of exploratory learning often take time, however, so it is natural that after spending time in nature, the students will continue to work on the material after returning to their school.

\section{The Nature Interpreters reflections}

The process of exploratory learning progresses in a controlled and cyclical manner through the following steps:

1. Context creation.

2. Problem setting.

3. Creation of the students' working theories.

4. Critical assessment.

5. Acquisition of new, in-depth information.

6. Developing more precise questions.

7. Creating theories that gradually become more specific. 
8. Shared expertise.

9. Publication of results.

The importance of shared expertise is specifically emphasised when reflecting on both your own research problem and content and the problems of others. Shared expertise is not specifically located under item eight in a chronological order, because it can be used in many stages, as necessary, while the study is in progress as a means of sharing, reflecting upon and deepening knowledge.

Learning that takes into account the personal learning style of the learner is at the core of exploratory learning. This contributes to guiding the learners towards learning through channels that work for them personally. Using the senses is a significant part of the whole process. When determining the nature of the projects, the sensory perception of nature is appreciated as one tool for collecting information. While the audiovisual aspect is a strong element in projects completed using tablet devices, it does not prevent involving the other senses in the study. For example, a group studying the archipelago environment in Suomenlinna can record or describe the scents of plants as part of the material collected.

Walking around in nature is also significant in terms of experiencing the environment.

In the Mobile Learning Environments project, the students explore issues related to nature and the environment in six different environments. The parties involved in the project include:

1. The Finnish Youth Centre Association. Located at the natural environment and historic fortification of Suomenlinna, which is on the UNESCO World Heritage List.

2. At Harakka Nature School, the students may study the unique maritime environment of the island.

3. The Töyhtöhyyppä Nature School (in Gardenia) in the Viikki Nature Reserve.

4. At the Helsinki Youth Centre's Nature House in Meriharju, the students can familiarize themselves with the maritime nature of Uutela in Eastern Helsinki.

5. In the Nature Scool Arkki, in Helsinki Zoo, the students can study both nature and animals.

6. Heureka, The Finnish Science Centre, offers perspectives on research and science as well as the chance to meet with experts.

7. Two Comprehensive Schools in Helsinki: Kallahti and Käpylä. 
The aim of the project is for the students to take part in developing each area based on its special characteristics. For example, the tasks challenge the students to create game-like features at the destinations. The game-like nature of learning is developed using a social media map application. At the moment, the Grafetee mobile application is being tested. The contents of the games are considered together with the students. In the Suomenlinna area, the participation of students in developing the area from a tourist's point of view is being planned - how does a child see Suomenlinna?

Participatory involvement and in-depth analysis of the environment when creating games enhances the students' understanding of the natural environment surrounding them. The viewpoints of environmental protection and moving around in nature can also easily be included as background features in the games.

Through exploratory learning and participatory pedagogy, it is easy to link the content currently being discussed to the project and move away from the traditional classroom space towards authentic learning experiences. Leaving the classroom behind will also help teachers dissociate themselves from ties to a particular subject. Replacing study based on school subjects with the study of phenomena and themes will create a more authentic basis for learning.

The Mobile Learning Environments project creates effective practices for using today's mobile devices when teaching at school and in learning environments outside the school. The project uses social media, map applications, online platforms, a blog, image services, online storage, tablet devices and other media devices.

\subsubsection{The Grey Lady's fairytale forest}

Storyline is a useful method in involving children. Many types of sensory exercises and drama are used effectively in this programme. Drama takes you from exercise to exercise and helps to reflect what you learn.

- Targetgroup: Children aged 3-8 from day-care centres and schools.

- Key words: senses, story line as motivator, biodiversity, active learner.

- Contact: Kirsi Sali, Environment School Regina/Youth Centre Anjala, Ankkapurhantie 15, 46900 Anjala, Tel: +358 20615 6332, Mail: kirsi.sali@kouvola.fi, www.nuorisokeskusanjala.fi

Description of the example

Aim of the activity: 
- Getting to know fairytales and forest animals.

- Getting to know some of the most common plants and animals.

- Learning to be observant and to use all the senses when walking in nature.

- Learning to appreciate nature.

- Learning to act alone and in a group.

The national curriculum states that the aim in the teaching of many subjects is to learn by experience. For example, this helps the pupil to form a positive relationship with nature and the environment. The national early childhood education plan stresses observation, exploration and experimentation as the means through which a child can form an idea of both animate and inanimate nature.

The ghost of Anjala Mansion, the Grey Lady, shows the children her fairytale forest. In the forest, the Grey Lady tells them the story of Thumbelina. The fairytale combines various exercises to sensitise the children to the environment, some of which are familiar from the Earth Education programme. At the same time, the children are introduced to common animals living in the wild, including frogs and mice. At the end of the excursion to the forest, the children go back inside to create their own "miniature worlds" using natural materials. The excursion in the forest takes approximately $1.5 \mathrm{hrs}$ and the craft activities approximately $1.5 \mathrm{hrs}$. A lunch break can be taken in between.

1. Introduction: "I am the Grey Lady and I live here in Anjala. I am very fond of nature, children and birds. I have my own secret fairytale forest nearby. Come with me, let's go to my magic forest!"

2. "I always tell the children a story when we are in the fairytale forest. Today, I will tell you the story of Thumbelina. Have you heard about her? The children read the first fairytale card: "Thumbelina is a little girl who was born inside a tulip. She lived with an old woman, who made her a bed out of a nutshell and a blanket out of a rose petal."

The group spends a moment thinking about how small Thumbelina is.

\footnotetext{
"Now you can all see for yourselves how small you can be. We will go through a gate that will take us to the Valley of Thumblings. Remember that once you step through that gate, you will only be as tall as your own thumb. Lift up your thumbs. It will help you understand how big you are."
}

The instructor walks through a "gate" and stops under a big tree. The children can sit, squat down or lie on their backs under the tree. 
"Now that we have come into the valley, you can all sit down comfortably. When you have found a nice place for a thumbling to sit, go and lie beside it. Now you see how different the world is when you are looking at it from the height of your own thumb. After you have looked at the view alone for a while, show it to somebody else. Doesn't everything look very big?

Now it is time to go back the way we came. Have one last look at the Valley of the Thumblings. Isn't it a wonderful place?" Source: Earth Education.

3. The group goes a bit further. The children read the second fairytale card: One day, when Thumbelina was sleeping in her bed, a frog jumped in through the window. The frog decided to bring Thumbelina to his son for a wife and took the girl and her bed to a lily pad. "Have you ever seen a frog? How do frogs move around? Let's try hopping like frogs. Did you know that toads do not hop, but walk instead. And did you know that there are three species of frogs living in Finland: common toads, frogs and moor frogs. A toad goes "croak-croak," a frog goes "kurr-kurr-kurr," but the moor frog, which is the smallest, goes "blup-blup-blup." The children hop...walk...make noises like frogs.

4. The children move on to the third fairytale card: Thumbelina did not end up as a frog's wife after all, because the lily pad starting drifting down the river. A flying cockchafer snapped Thumbelina up from the lily pad and took her to the forest, to the other cockchafers. "Do you know what a cockchafer is? It is a flying beetle that has funny antennae that stick out just like arms (the instructor lifts up her hands on either side of her head like antlers). The cockchafer's sense of smell is in its antennae, so it uses them to smell. Let's fly around like cockchafers, with our antennae ready to explore each other." The children fly around like cockchafers and examine each other with their antennae.

5. The children move on to the fourth fairytale card: Thumbelina ended up at the edge of the forest, where she lived all summer and played with the woodland animals. The sun shone, and sometimes when it rained, a rainbow shimmered in the sky. "Actually, we have pieces of a rainbow here, too. Can you see them? Look over there - and there! When I was walking here last week, it was drizzling, and a rainbow appeared in the sky. It was shining in all colours. It was such a wonderful sight that all I could do was stand and stare at it. But then, all of a sudden, the rainbow fell out of the sky, and little pieces of it were scattered on the ground. I went around quickly and picked up as many pieces as I could. Here you go, these are fragments of a rainbow." The instructor 
opens a bag that contains coloured strips cut out of paint catalogues. "Would you like to find pieces of a rainbow for yourselves? You can all take a few strips of colour. Then go and find something that is exactly the same colour. It may help to keep the piece at an arm's length from yourself. This will help your eyes focus. When you find something that is the same colour as the rainbow, tell somebody else." After everybody has spent some time looking for the colours, the group discusses where various colours can be found. Source: Earth Education.

6. The children move on to the fifth fairytale card: When autumn came, Thumbelina was looking for a warm hole for a nest at the edge of the field. A tiny field mouse then gave her a home for the winter. They went to visit a blind vole, who fell in love with Thumbelina. In the vole's tunnel Thumbelina found a swallow who had hurt its wing. Thumbelina looked after the swallow until the wing healed, and when spring came, the swallow flew off to live in the forest.

7. The children move on to the sixth fairytale card: As autumn came, the blind mole wanted to marry Thumblina. He had fallen in love with her voice. "Blind people cannot see what is around them. For that reason, their other senses have become more accurate. You can now practice your sense of touch by collecting various touches in very special touch boxes." The instructor gives small groups of children egg boxes. "Each group can collect ten different touches in this box. When you have finished collecting them, close your box and bring it over here. The groups can then examine the touches collected by the other groups, and try and guess whether they are soft, hard, wet, dry, cold, hot, etc." NB! The children can take the egg boxes with them to the crafts area, and the touches can be used in the craft activities later on in the day. Source: Earth Education.

8. The children move on to the seventh fairytale card: However, Thumbelina did not want to marry the mole. When the swallow came to say hello, and asked her to fly south with him, Thumbelina went with the swallow. They arrived in a warm country and settled down. One day, Thumbelina saw a wonderful sight. A small, thumbling-sized boy flew to her! The boy was the prince of fairies, and he wanted Thumbelina to come with him to the fairies. And so, Thumbelina lived with the fairies happily ever after. "This is the end of the story. How did you like my fairytale world?" The group discusses the excursion. "Look, Thumbelina and the prince of fairies have come out to that branch to say hello to us!" (two dolls have been placed on the branch in advance) "Let's take Thumbelina and the prince with us and go have something to eat." 
Lunch break.

9. After the break children come to a circle, and story and the exercises done together are repeated. Children can tell their experiences from the trip.

10. The children get a new task: how the story of Thumbelina continues? What happens to the animals Thumbelina met? Children can create the story together in a big group (the youngest), or have smaller groups (preschool and older ones). They can create a drama or a puppet show or a drawing.

Figure 8.15

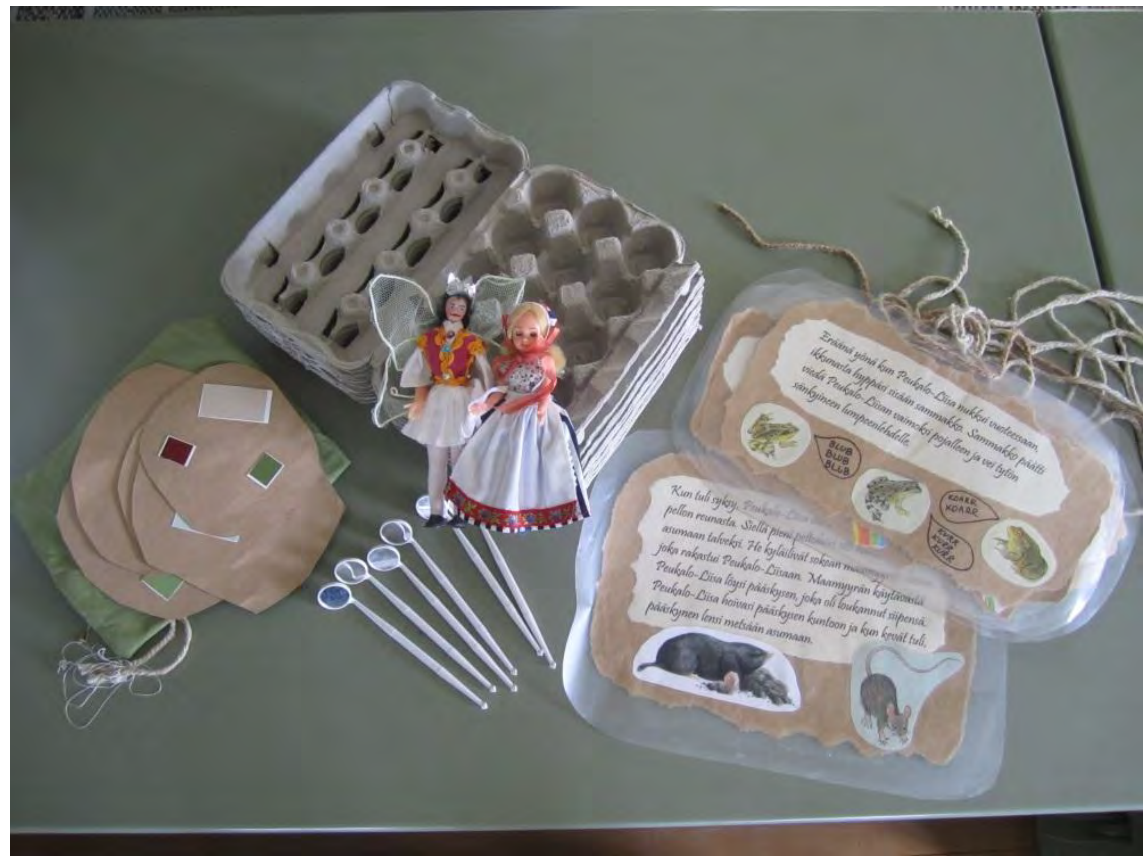

Photographer: Juhani Kärki.

\section{Equipment needed}

Laminated fairytale cards, colour strips; for the winter supply game, five bags, a container and grain; egg boxes, a Thumbelina doll and a prince doll. The supplies should be left in the selected places before the excursion. The group carries a first-aid bag throughout the excursion, for example in a basket.

For the crafts, cones, moss (remember to ask the landowner's permission), lichen and other natural materials should be collected in the woods before the excursion. The crafts area should be set up in advance. 
In addition to natural materials, for example sand, bits of wood, wooden discs, etc., can be used.

\section{Working with the story afterwards}

The group can work on their fairytale pictures or worlds and create stories, drawings or plays. The group can also develop the story of Thumbelina further and create stories and drawings about her life.

\section{The didatics of the activity}

The group is led by a single instructor (the Grey Lady), and joined by the group's own teachers, who are encouraged to actively take part in the tasks and games. Each task is explained to the whole group together once everyone has settled down and is listening. The fairytale card is read slowly, and the instructions for the tasks are given clearly and in short sentences. The group discusses the task after it has been completed, and the children can tell what they did and experienced. The instructor, the Grey Lady, strives to take all children in the group into consideration and to talk to them during the programme. She encourages them to complete the tasks and admires the results. The instructor can also create a safe atmosphere and inspire trust in the children by touching them lightly, for example by stroking their heads or patting them on the shoulder.

Questions that encourage reflection are put to the group; for example, what it would be like to be very small, how they felt about collecting food for the winter, how a blind person perceives the environment, etc. During the excursion the instructor can talk to participants and ask them in more detail about how they would cope during the wintertime if there was no food supply, etc.

Many types of sensory exercises are used in the programme.

Above all, the participants are required to be active in the games that they play together and in the winter food game. Finding different colour tones and touches requires problem-solving skills. Active participation and problem-solving skills are also required for the craft activities.

The programme will enhance the children's sensitivity to the environment and give them tools for looking at the ordinary environment from different perspectives. This will deepen the children's relationship with nature, which is the first step on the road to them becoming citizens who have a positive attitude towards the environment.

If the instructor meets with the children after the excursion, she can revisit it through stories and plays that they create together. This programme is a good example of our activities, because it combines an old, well-known fairytale and various environmental sensitivity exercises. 
If you want to strengthen the story line in the program also the participants can have role dresses like the instructor, for example aprons/vests and scarfs/caps. You can also make an own story, you don't have to use a known fairy tale. Then you can add more things from conservation of nature: children can for example solve some environmental problem, which could lead the story to different direction. This way we could also talk about small problems, like littering, and give some examples to the children. So they could learn that they have an impact to their environment (this case the story line. Environmental problems are too hard to understand for 3-6 years old, so I would use this only with children over 6 years.

\subsubsection{The shy and the beautiful, the bold and the ugly}

Drama is a way of figuring your pace as a part of nature and raise the interest for animals.

- Target group: Early childhood education, lower comprehensive schools, youth activities, adults.

- Key words: animals, bodily experience, creativity, co-operation.

- Contact: Riitta Nykänen, Metsähallitus Pohjanmaan Luontopalvelut, Syväyksenkatu 22, 89600 SUOMUSSALMI, Mail:Riitta.nykanen@metsa.fi

\section{Description of the example}

Creating characters based on observation and experiences, and producing a story, a description of an event or another such dramatized description of experiences.

Discuss with the group what the theatre and drama are. Stress the importance of listening ad creating together. Listening is more than just hearing the words: How can I understand the other and give him/her the space he/she needs.

To start with, the participants examine together the shapes of different animals, how they breathe and move in various situations, and what types of movements they display through the use of pictures, earlier personal observations and possibly a moving image.

The participants try and imitate together the various rhythms, breathing and general movements of the animals as well as their dynamics. They move like animals. They watch various suggestions for imitating animal behaviors. They think about the features that various animal groups share, such as wing and limb movements, head position, the length of their steps, speed. 
The instructor helps each participant decide which animal he/she would like to study in more detail, with the aim of trying out how it would feel to be that particular animal.

The participants use various methods to examine how their selected animals make noises, eat, act when startled, rest, hide...thus finding material for creating animal characters. If you need to talk during the drama, you could figure out what kind of voice would the animal have.

The participants decide which animals could be featured in the same story, and thus groups are formed. A suitable number of participants in a group is 3 to 5 . The groups get together to think about a story that they could start developing into a drama. The stories may, to various degrees, be based on truth. You could also work so that same spices work together, develop the characters of each other and create a story.

When the groups start sketching their ideas, the instructors help them, that is if they need help. The animal characters can be humanized to various degrees, but it is a good idea to agree together on what the animals can do in the story and to what extent the characters are humanized.

The stories are performed and praised. After each performance, the participants talk about what was funny, what part of the characters' actions showed clever insights, how the stories might continue.

\section{Working with the theme before the visit}

It may be better not to do any preliminary work, but the groups may gradually start watching moving images of animals and observe their movements and breathing.

\section{Reflections on the didactics}

To start with, the group warms up by playing games and running around, create feeling of flow and get vigilant. The participants gradually progress to the actual creation of the story. The instructors ensure that everyone feels that they are successful at creating the character. An instructor that knows the group is involved, for example in forming the groups and directing the task. Participants are engouraged to play together in their animal roles.

The entire programme consists of reflection and consideration and creating a story and characters based on what the participants have experienced. Participants examine the parts of the stories that have been played and the animal characters, and observations are discussed. 


\subsection{Eksempel fra Island}

\subsubsection{Vatnshellir - Visit the cave}

Experience a cave with all the senses. Reflect on the visit by using music, poems and drawings. This can lead to interesting discussions about species survival.

- Target group: Schoolgroups 6-15 years old.

- Keywords: Use singing, writing and drawing for reflection on the visit to the cave. Making connections to science.

- Contact: Guðbjörg Gunnarsdóttir, Pjóðgarðurinn Snæfellsjökull, Klettsbúð 7, 360 Hellissandur, Mail:gudbjorg@ust.is

\section{Description of the example}

A visit to the cave starts with an introduction on the park and nature conservation, on the cave and how to behave in caves. "Take nothing, leave nothing behind."

The children are asked to make sure that the adults who are with them behave well!

They all get helmets and lights and go down to the cave. We explain the geology in a simple way using things they know. We also turn on their imagination and ask them if they see any figures in the walls of the cave. Sometimes they make stories about the figures. We go down some 30 meter and there we turn off the light. We keep quiet for 1-2 min., listening to the sounds of the cave that has sounded like this for thousands of years, until we came. We also smell and there is hardly any smell at all. We sing in the dark and then we put one light on and see how brightly it shines. We also tell them about the use of caves in old times and skeletons of animals that have been discovered.

\section{How to enhance reflection among the visitors/children}

Down in the cave, Mother Earth is talking to the children, embracing them with the darkness.

\section{Connection with arts}

The children could express their feelings in the cave by painting a picture when they are back at school. This is not allowed in the cave itself. They could also make music, based on the sounds of the drops in the cave. They could even record the sounds of the cave and make a short documentary video about the visit, using the sound of the drops in the 
background. Each of them could then have a disk with the video or it could be published on YouTube.

\section{Connection with the language}

The children write a poem about their experience in the cave. Each of them could make one sentence, write it down in school and together they would put the sentences together, making a poem.

\section{Connection with science}

The children cannot take samples of the bacterias living in the cave, only scientists can do that. But the children could get informations on the bacterias from the scientists. They could use their imagination and discuss how it might be possible to use the bacterias (grown in laboratories). What changes could happen to the cave if there were too many of the bacterias or if they would become extinct?

\subsection{Eksempler fra Færøerne}

\subsubsection{At følge Storgærdet}

Vi følger levningerne af det gamle stengærde som i sin tid omkransede Torshavn og som adskilte fjeldområdernes husdyrgræsning fra den dyrkede mark.

- Målgruppe: 1.-3. klasse (6-9 år).

- Nøgleord: lokalhistorie, kultur, respekt for forfædrenes arbejde.

- Kontakt: Jón Kragesteen, Tórshavnar Kommuneskole, Tórsgøta 25

- F0 100 Tórshavn, Føroyar, Mail:jon.kragesteen@skulin.fo

\section{Beskrivelse af eksemplet}

1. At bevæge sig langs stengærdet (5-6 kilometer).

2. At studere hvordan stengærdet er bygget op (store sten nederst - kan mennesker løfte de største sten?).

3. At finde hvor gærdet fortsætter efter et brud på grund af bygning af huse.

4. Vurdere hvor lang tid det har taget at bygge gærdet-og hvor kom stenene fra?

5. Hvor slutter gærdet? 


\section{Materialer}

Spade, kniv, 2 klare krukker til vand. Skrivebræt (vandfast papir, som gør det muligt at skrive og tegne selv om det regner), blyant, foto/film-udstyr.

\section{Klassens forberedelse}

Læse/høre foredrag om baggrunden for, at stengærdet blev bygget. At stengærdet fortæller fattigmændenes kamp om at få deres egen jord at dyrke og til dyr.

Tale om nytten af stengærdet.

\section{Efterbearbejdning af aktiviteten}

Gennemgå billeder og snakke om de ting, de forestiller.

Skriveopgaver om emnet: skrive frit/diktat. Forskellige former for gruppearbejde.

Eleverne får spørgsmål om fakta omkring åen og lokalområdet, som de skal løse hjemme ved hjælp af forældrene. Spørgsmålene kan formuleres som påstande som kan give anledning til diskussion med forældrene.

\section{Naturvejlederens refleksioner}

Faste rutiner: Undervisningen ude i naturen noget der sker hver uge, en fast dag, uanset vejret. Eleverne ved, at turen varer 2-3 timer.

Der er indlagt fast frokostpause, som holdes et indarbejdet tidspunkt.

Klare regler om adfærd i trafikken, hvor man skal gå to og to. For at undgå at nogen bliver udelukket, bliver parrene skiftet, så at alle kommer at følge hinanden gennem et skoleår.

Når klassen bevæger sig i naturen, går man frit. Læreren forsøger at komme rundt og at få en snak med alle.

\subsubsection{Børns nysgerrighed for naturen vækkes gennem jagt på planter}

- Målgruppe: 6-8 årige.

- Nøgleord: Feltundersøgelser, opdage planter med alle sanser.

- Kontakt 1: William Simonsen, Blómubrekka 54, F0 100 Tórshavn, Mail:william@savn.fo

- Kontakt 2: Herborg N. Debess, J. Paturssonargøta 37, F0 100

Tórshavn, Tel: +298 311395/+298279312, Mail:hnyd@kallnet.fo

\section{Beskrivelse af eksemplet}

Det overordnede mål med projektet er at øge børnenes naturlige opmærksomhed, interesse og nysgerrighed for natur og miljø i det hele taget. Det er vigtigt at fange børns interesse for naturen og dens 
bæredygtighed så tidlig som overhovedet muligt. I denne forbindelse er der i den grad brug for sanserne og det er børn gode til. Giver deltagerne erfaringer at bruge, når de i skoleforløbet når til biologien. Planter skal identificeres i den spirende fase.

Optakt til aktiviteten: Naturvejlederen informerer (i dialog med deltagerne) overordnet om flora i det hele taget og om, hvilke planter aktiviteten handler om.

Lad deltagerne fortælle om erfaringer og forhåndsviden - luk op for spørgsmål.

Materialet der skal bruges udendørs, præsenteres og der fortælles, hvordan aktiviteten skal foregå.

Fysisk aktivitet: Ud at lede efter planter med udleveret billedmateriale som støtte. "Fangsten" skal plukkes og presses på stedet. Plantens navn skal straks skrives i hæftet. På turen bliver deltagerne gjort opmærksomme på, hvordan planterne udfordrer vores sanser:

- Lugt eks. en art timian Thymus praecox krydrede lugt.

- Smag eks. almindelig syres Rumex acetosa sure smag.

- Følesans eks. benbræks Narthesium ossifragum gummiagtige blade.

- Syn eks. deltagerne gøres opmærksomme på planternes farves og mønstres betydning i forhold til bestøvning.

- Andet eks. gå barfodet på græs eller mos.

Indendørs: Planterne tegnes lige efter aktiviteten.

Billede 8.16

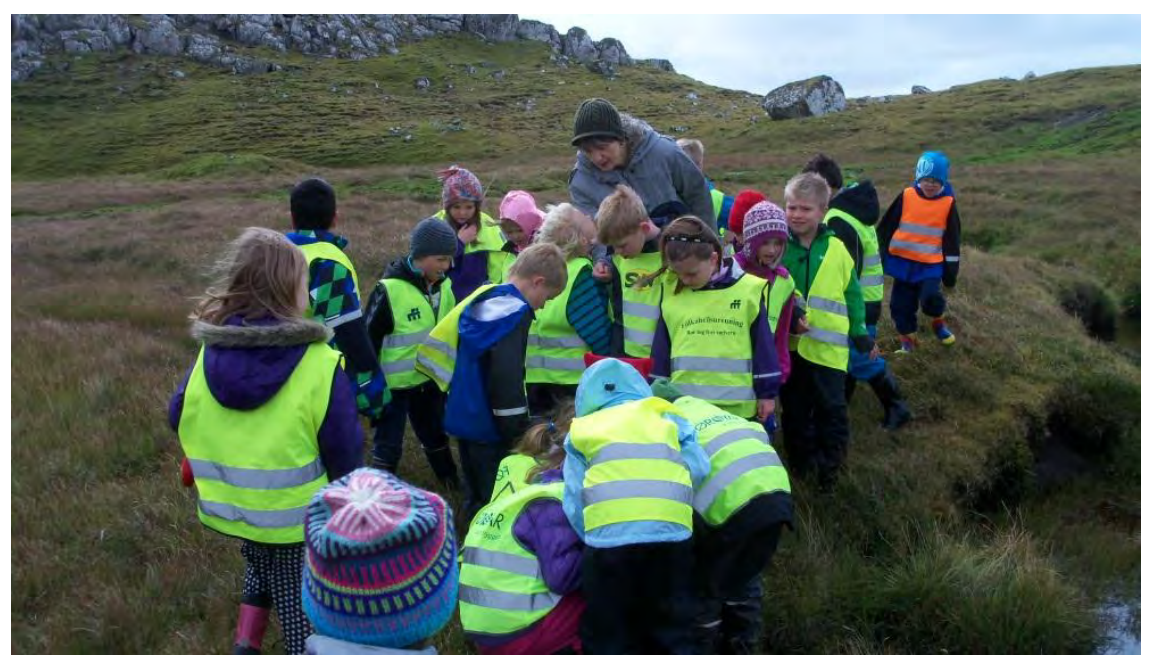

Fotograf: Herborg Debess. 


\section{Udstyr og materialer}

- Små "handy" laminerede ark med billeder og tekst af en bestemt plante skal laves - illustrerende f.eks. planten i dens forskellige faser og plantens habitat.

- Beskrivende tekst: er den f.eks. nytteplante (til hjælp mod sygdomme eller som føde/krydderi?).

- Arkene skal kun have tekst/billeder på den ene side, så de kan bruges til ophængning/udstilling. I nogle tilfælde skal billeder være større og teksten skal være med store staver og ikke så ordrig.

- Det laminerede ark skal have en elastik fastbundet, så det kan hænge i håndleddet.

- Små notesbøger - gerne med plastomslag - til presning på stedet.

- En blyant fastbundet til hæftet.

- Tegne- og farveudstyr.

- Medbring et sæt forstørrelsesglas.

\section{Skoleklassens forberedelse}

Læreren skal lukke op for emnet i dialog med eleverne om planters betydning i vores livscyklus - f.eks. fotosyntese og planters betydning for dyr (føde, skjul, bolig etc.).

Der kan kigges i bøger om vores flora, laves opgaver, læses historier, sås frø til iagttagelse.

\section{Hjemme på skolen efter aktiviteten}

Når de pressede dele er tørre, laves en udstilling af undervisningsmaterialet, de pressede planter og tegningerne.

\section{Om medindflydelse}

Når naturvejlederen har de samme elever med ud i løbet af et helt skoleår, kunne eleverne få lov til at komme med forslag til aktiviteter og til arten af undervisningsmateriale. Evt være med til at udforme materialet - dette for at øge følelsen af ejerskab af projektet.

Understreg, at aktiviteten ikke er en konkurrence. Gør det klart for børnene, at det er mindre vigtigt, hvad de finder eller om de finder det rigtige - det er mere vigtigt, at de kan beskrive, hvordan de finder det. Har de brugt syn, lugt, følesans, forhåndsviden o.s.v.

Lad børnene beskrive, hvordan de opdagede planten.

Vær forberedt på at aktivere de børn, der er særlig hurtige til at opdage planterne, med andre spørgsmål - de kan evt undersøge, hvad de ellers finder på vækststedet (andre planter, smådyr) - for at give resten af gruppen mere rum og tid. 


\section{Om refleksion}

Historiefortælling med indhold, der omhandler det aktuelle emne. Snakke om planten som evt. nytteplante.

Refleksion hos den enkelte: Undersøgelse af vækstområder hvilke dyr findes i nærheden - hvorfor planterne er føde, skjulested etc., og hvorfor lige præcis disse dyr (bestøvning f.eks.?).

Målet er først og fremmest at vække deres nysgerrighed - tillige gennem oplysning og dialog om f.eks: forureningens virkning på planter? Hvordan dræning af områder reducerer muligheden for liv i moser og enge? Hvilken skade invasive arter kan gøre?

Der er meget stor forskel på, om naturvejlederen møder de samme elever en eneste gang eller gang på gang/evt. ugentlig.

I forbindelse med dette projekt er der tale om, at vejlederen og eleverne er på samme skole hele tiden - ikke i "natursammenhæng," men dog på samme sted.

Selve projektet er fortløbende i et par timer en dag om ugen, men videreudvikles hele tiden med daglige elevspørgsmål og tilpasses derefter. Det er ikke muligt at køre med samme koncept, fordi eleverne som regel er de samme hele skoleåret - og de skulle nødig komme til at kede sig!

\subsubsection{Sedna-Havet, strandzonen og båden}

Unge mennesker tages med ud på havet, hvor de lærer om betydningen af at atge ansvar, at samarbejde og at have repsekt for naturens kræfter. Målet er stærke naturoplevelser og måske begyndelsen på en uddannelse til havs.

- Målgruppe: Elever som er 16 til 17 år gamle. Det er overvejende drenge, som har valgt fiskeri og havkundskab som linjefag. Formidlingen foregår over flere dage. Karakteristika for målgruppen er drenge, som ikke har klaret sig specielt godt i den gængse undervisning på skolen. De har et højt energiniveau og interessen forsvinder hurtigt, hvis der ikke foregår noget som fanger dem. De er tit høje og kluntede og tit meget usikre på dem selv og højt råbende. Typiske teenagerdrenge.

- Nøgleord: Sejlads på havet, samarbejde, mad fra naturen på naturens vilkår.

- Kontakt: Anna Louise Joensen, Nám X Eysturskúlin, Tel: +298 522787, Mail: joensens@live.com 


\section{Beskrivelse af eksemplet}

Færøerne er omgivet af hav til alle sider, et så overvældende element, at man er tvunget til at tage stilling til, om man vil prøve kræfter eller opgive på forhånd. Traditionelt har færingen overlevet årtusinder på klippeøerne på grund af de færdigheder og det kundskab som man har udviklet gennem tiderne. Denne viden er desværre ved at forsvinde fra folks bevidsthed. Dette er ærgerligt, fordi man har et meget fint udviklet eksempel på, hvordan mennesket kan leve i harmoni med havet ud fra havets vilkår. Kun en tåbe frygter ikke havet, men det betyder ikke at man skal holde sig væk. Derimod er det en fantastisk mulighed at lære at opføre sig på naturens principper. I en robåd ude i strømhvirvlerne mod vinden, er viden og respekt et spørgsmål om liv eller $\mathrm{d} ø \mathrm{~d}$ i bogstavlig forstand.

\section{Billede 8.17}

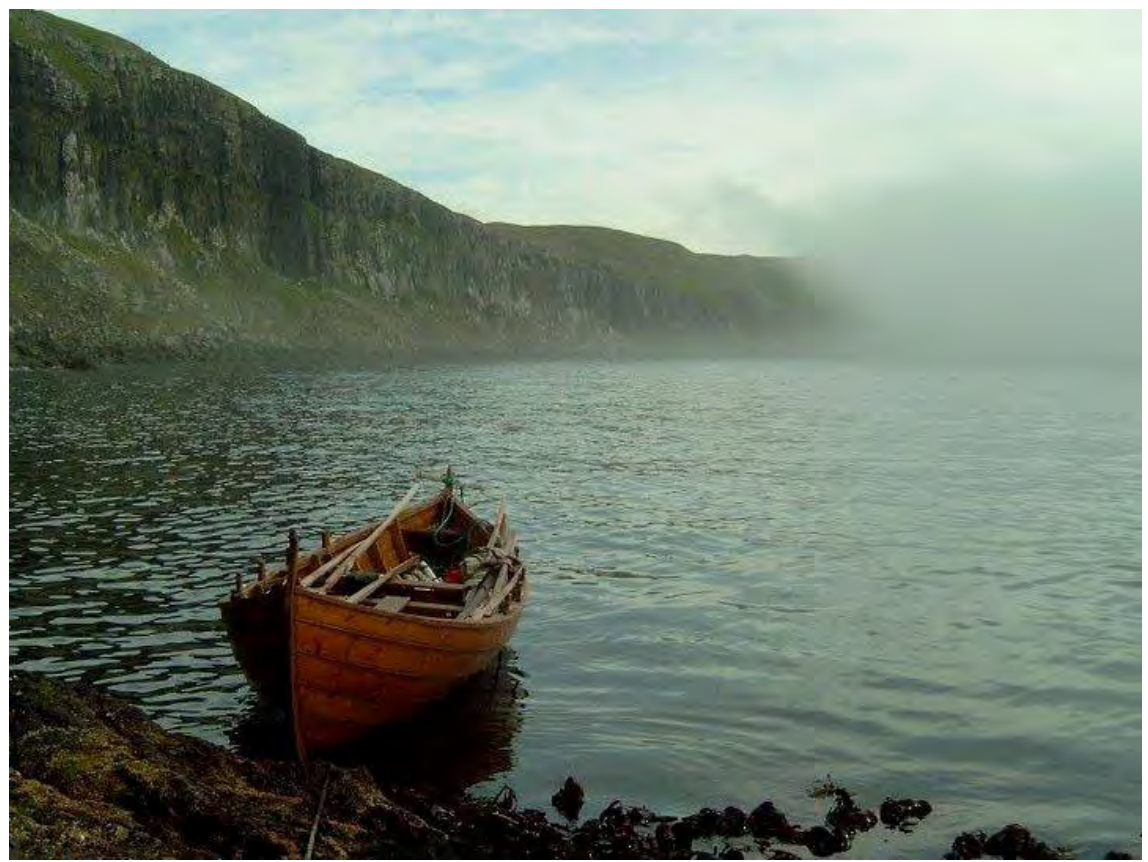

Fotograf: Anna Louise Joensen.

Formidlingen af dette forløb foregår i en robåd af træ af 8-mandsfarer type som jeg kalder Sedna, havets gudinde. Båden er bygget efter gammel tradition og blev brugt til havfiskeri I gamle dage. En vigtig epoke I den færøske historie er betinget af netop denne type robåde. Folks overlevelse var afhængig af, om de kunne skaffe sig mad fra havet. For at kunne gennemføre 
en fisketur, måtte man have et stort kendskab til naturen og have grejet I orden. Man måtte også være fysisk stærk og kunne roteknik.

Disse elementer er indbygget I formidlingen af denne session. De første timer drejer sig om strømforhold og hvordan man klæder sig på til omstændighederne. Dette foregår I klasselokalet.

Grunden til at jeg bruger tid på forberedelserne inden selve turen, er at vejr og strømforholdene på Færøerne er meget barske og man skal vide hvad man gør ellers kan en farlig situation hurtigt udvikle sig. Dette får eleven at vide inden vi begiver os ud.

For at kroppen skal kunne fungere optimalt, må man være godt klædt på. Varm trøje, gummistøvler let regntæt overtøj og hue og vanter. Redningsvest er standard og skal hele tiden blive brugt. Disse ting skal være I orden for at man kan ro optimalt og være en pålidelig del af mandskabet. En god madpakke er også vigtig, hvis man skal være flere timer ude på havet.

Eleven får også en kort indføring I strømforhold og hvordan man kan regne ud hvordan strømmen løber. Senere om vinteren făr de et mere indgående kendskab til disse ting og lærer selv at regne strøm og vurdere vejrforholdene.

Formålet med denne indføring er at kunne gå ud I en potentielt farlig natur og kunne færdes trygt og få de store oplevelser med hjem.

Drengene får at vide, at der er en kaptajn på Sedna. Det er meget vigtigt, at der bliver pareret ordrer, når man er ude på vandet. Der skal ikke forekomme farlige situationer på grund af pjank. Hele konceptet og oplevelsen er baseret på sikkerhed og viden, ellers er det ikke forsvarligt at begive sig ud på sådan et eventyr. En veldefineret ansvarsfordeling er grundlaget for trivsel og tryghed, når man er under sådanne forhold.

Selv om der er meget faste rammer, er der rig mulighed for at komme med forslag og stille spørgsmål undervejs. At jeg som kvindelig instruktør i et så mandsdomineret miliø, har absolut sine fordele. Drengene har meget nemt ved at spørge om hjælp og det er ikke pinligt at spørge mig om ting, som man måske forventede at en dreng i den alder vidste i forvejen i forhold til at stille en mand samme spørgsmål.

Når disse ting er på plads, går vi ned til strandzonen som vi kalder fjørðan. Her kan man finde mange forskellige muslinger, som er velegnet til agn eller madding. Her får man også lejlighed til at kigge nærmere på selve naturen, hvordan den er formet af bølgerne og på vegetationen, specielt tangplanter. Vi står et øjeblik og iagttager fuglelivet og skyerne for at orientere os og opleve. Her kan man også kigge på vandoverfladen og aflæse noget om strømmen og bølgerne og forberede sig mentalt til at tage ud på vandet. 
Det næste der sker, er at vi går ned på støðna, som er den lille lokale havn. Her ligger båden klar og venteren. Jeg giver en lille indføring omkring båden om roteknik og om hvordan man vender sig I en robåd. De får lidt at vide om hvordan det fungerer med takten, når man ror og hvad man skal gøre. De bliver gjort opmærksomme på at de faktisk skal føle rytmen i båden i stedet for så meget at kigge og tænke.

Fiskegrejet har man kigget lidt på inden man tog af sted. Vi bruger mest torskestang med store blink og lidt agn, men vi har også det traditionelle snøri med et tungt blylod og to kroge med agn, gerne makrel.

Af udstyr ellers, er alt det påkrævede sikkerhedsudstyr med om bord. Nødblus, nødraketter, kompas, tågehorn, radarreflektor, redningsveste og pøse. Almanak er også standardudstyr, her findes alle oplysninger om strøm og navigationsforhold som man har brug for.

Så kan vi kaste fortøjningen og begynde at ro. I starten er det så som så med rytmen, men da der næsten altid er en eller to af eleverne som er med I kaproning og kan teknikken og kan tage pladsen på lærið som det hedder, er det dem der styrer rytmen og de andre falder ind en efter en. Vi ror ud mod Gulanum der ligger lidt syd for Thorshavn, hvor der er fiskepladser man næsten altid kan fange torsk. Ofte fortøjer vi i en bøje, som ligger der ude. Dette gør at vi ligger stille på fiskepladsen og ikke behøver at ro tilbage hele tiden, fordi man driver væk med vind og strøm. Det er næsten fangst garanti og det er store flotte torsk vi fanger. Vi kan også fange gråsej, men de er ikke så populære som torsken. Når man har fået torsken ombord, er det vigtig at bløðga. Det er at skære I halsen så den dør og blodet løber ud. Senere når man er færdig med at fiske, kan man begynde at kryvja. Det er at rense fisken. Så har man rig lejlighed at kigge på indvoldene og se hvad er i mavesækken. Hvis fisken har en fin lever eller er med rogn, bliver det taget med hjem. Nogle gange bliver fisken bragt til hjemkundskab på Nám x og så der bliver lavet fiskefrikadeller.

En sådan fisketur varer gerne 3 til 4 timer. Min kollega har en motorbåd og sejler lang væk og sætter helleflynderline. Så er man væk en hele dag og har mulighed for at fange fisk på op mod $100 \mathrm{~kg}$.

Når vi er hjemme igen, lærer de at binde båden ordentlig. Her er der nogle vigtige knob som man skal kunne. Siden bliver fisken fordelt og brakt hjem. Efter en sådan dag har man nogle trætte og smilende drenge at tage afsked med.

Senere på året går vi op på Nationalmuseet og hører mere detaljeret om den færøske robåd. Her reflekterer vi omkring omstændighederne før i tiden og nu. Hvad er bevaringsværdigt og hvad er lige meget?

Vinteren går også med sysler som at rigge fiskeliner til og smøre båden med tjære og små reparationer. Drengene får også et professi- 
onelt kursus om sikkerhed om bord så de kan monstre som mandskab på et skib efter endt skolegang. De lærer selv at sætte kurs, regne strøm og tolke vejrkort således at de bliver i stand til selv at tage af sted ud og fiske.

Da aktiviteten foregår omkring den traditionelle færøske robåd, som efter min mening er højst bevaringsværdig og et fantastisk dokument på den æstetik og håndværksmæssige kunnen som man har oparbejdet helt fra vikingetiden, vil denne aktivitet øge bevidstheden og respekten for kulturhistorie og naturen og være med til at bibeholde det tætte samhørighed som færingen oprindelig har haft til naturen.

Vores gamle ordsprog som siger at færingen er født med åren i hånden, skal vi også i fremtiden kunne forholde os til og være en del af vores identitet. 
9. Appendix B/Bilag B 


\begin{tabular}{|c|c|c|c|}
\hline Navn & Adresse & Mail og tel $\mathrm{nr}$. & Rolle \\
\hline Aleksis Hahn & Kvarkens naturskola & aleksis.hahn@naturochmiljo.fi +358 404199756 & Deltager Finland \\
\hline Anna Louise Joensen & Nám X Eysturskúlin, samt privat ridecenter & joensens@live.com +298522787 & Deltager Færøerne \\
\hline Bjarne Christensen & Fredericia Kommune & Bjarne.christensen@fredericia.dk +45 25105552 & Deltager Danmark \\
\hline Elina Pilke & Metsähallitus, Natural Heritage Services & elina.pilke@metsa.fi +358 405813534 & Deltager Finland \\
\hline Felix Becker & Vesterbro Miljø- og naturværksted & Felix.christian.becker@okf.kk.dk +45 20337060 & Deltager Danmark \\
\hline Guðbjörg Gunnarsdóttir & Nationalparkleder på Snæfellsnes & snaefellsjokull@umhverfisstofnun.is* +354-4366860 & Deltager Island \\
\hline Herborg N. Debess & Frískúlin í Havn, Velbastađur & hnyd@kallnet.fo +298 311395 & Deltager Færøerne \\
\hline Ingvild Høyland & Norges Jeger og fiskerforbund & Ingvild@njff.no + 4792649535 & Deltager Norge \\
\hline Jon Kragesteen & Tórshavnar Kommuneskole & Jon.kragesteen@skulin.fo +298 220449 & Deltager Færøerne \\
\hline Juhani Kärki & City of Helsinki Media Centre & Jukani.karki@hel.fi +358 (0)31086988 & Deltager Finland \\
\hline Kirsi Sali & Environment School Regina & Kirsi.Sali@kouvola.fi +358 206156332 & Deltager Finland \\
\hline Kristoffer $\varnothing$ verland & Oslo og Omland Friluftsråd & krisoof@online.no +47 48287887 & Deltager Norge \\
\hline Leif H. Sørensen & Trente Mølle Natur-, miljø og Lokal Agenda 21 center & nv@trente.dk +45 62681979 & Deltager Danmark \\
\hline Michaela Lundell & Naturskyddsforeningen & michaela.lundell@glocalnet.net + 44 070-28 44075 & Deltager Sverige \\
\hline Daniel Åberg & Naturum Kullaberg & Daniel.aberg@lansstyrelsen.se Tel: 040-252392 & Deltager Sverige \\
\hline Per-Erik Schulze & Naturvernforbundet & pes@naturvernforbundet.no +47 41856697 & Deltager Norge \\
\hline Peter Eriksson & Stensjögård & stensjogard@gmail.com + 46176263322 & Deltager Sverige \\
\hline Petter Jørgensen & Kragerøb arne- og ungdomsskole & Petter.jorgensen@kragero.kommune.no +4792255593 & Deltager Norge \\
\hline Riitta Nykänen & Metsähallitus & Riitta.nykanen@metsa.fi +358 408251918 & Deltager Finland \\
\hline Sofie Lindblom & Naturum Hprnborgasjön & Sofie.lindblom@lansstyrelsen.se +46 1+ 2245659 & Deltager Sverige \\
\hline Stein-Roar Slotter $\varnothing y$ & Dalane Friluftsråd & naturligvis@friluftsrad-dalane.no & Deltager Norge \\
\hline Thor Hjarsen & Red Barnet Danmark & thj@redbarnet.dk +45 40113373 & Deltager Danmark \\
\hline Vibe Winckles & Naturskolen ved Hald & viw@viborg.dk +45 20199612 & Deltager Danmark \\
\hline William Simonsen & Føroya Náttúrugripasavn, Søvn landsins & William@savn.fo +298 790579 & Deltager Færøerne \\
\hline Navn & Adresse & Mail og tel nr. & Rolle \\
\hline Søren Breiting & Danmarks Pædagogiske Universitet, Danmark & breiting@dpu.dk & Oplægsholder \\
\hline Lill-Ann Wolff & Åbo Akademi University Faculty of Education, Vaasa & liwolff@abo.fi +35863247413 & Oplægsholder \\
\hline Navn & Adresse & Mail og tel $n r$. & Rolle \\
\hline Mette Aaskov Knudsen & Skov \& Landskab, Københavns Universitet & mek@life.ku.dk & Projektleder \\
\hline Brita Homleid-Lohne & Statens Naturoppsyn/Direktoratet for Naturforvaltning & Brita-Homleid.Lohne@dirnat.no & Projektgruppe N \\
\hline Carina Wennström & Metsahällitus, Forststyrelsen & carina.wennstrom@metsa.fi & Projektgruppe Fin \\
\hline Eva Sandberg & Centrum for Naturvejledning, SLU, Uppsala & Eva.k.sandberg@slu.se & Projektgruppe $S$ \\
\hline Niina Mykra & Finlands natur- och miljöskolförbund & niina.mykra@luontokoulut.fi & Projektgruppe Fin \\
\hline Per Sonnvik & Centrum for Naturvejledning, SLU, Uppsala & Per.Sonnvik@slu.se & Projektgruppe $\mathrm{S}$ \\
\hline Poul Hjulmann Seidler & Skov \& Landskab, Københavns Universitet & phs@life.ku.dk & Projektgruppe DK \\
\hline Ragnar Frank Kristjánsson & Agricultural University of Iceland & ragnarf@Ibhi.is & Projektgruppe is \\
\hline Torfinn Rohde & Statens Naturoppsyn/Direktoratet forNaturforvaltning & torfinn.rohde@dirnat.no & Projektgruppe $\mathrm{N}$ \\
\hline Trondur Leivsson & Umhvørvisstovan, Environment Agency, Færøerne & trondurl@us.fo & Projektgruppe Fo \\
\hline
\end{tabular}




\section{Appendix C/Bilag C}

\subsection{Workshop in Östersund $17^{\text {th }}-19^{\text {th }}$ September 2012}

\section{The aim}

To discuss and develop approx. 60 nature interpretation examples with a special focus on:

- Urban nature.

- Protected nature.

- Cultural Heritage sites in the landscape.

The examples are supposed to contribute to the development of Nature Interpretation Methods that promote learning and democracy.

We're especially interested in activities that contribute to the motivation for participation in democratic processes in nature conservation, use and management.

\begin{tabular}{|c|c|}
\hline Mon. $17^{\text {th }}$ Sep. & \\
\hline During the morning & Participants arrives. Accommodation at the Hostel \\
\hline KI. 13.00-14.00 & Lunch/Restaurang Hov \\
\hline KI. $14.00-15.50$ & $\begin{array}{l}\text { Welcome to the workshop and the Nordic Project. Mette Aaskov. Welcome til Jamtli. } \\
\text { Henrik Zipsane, head of Jamtli Museum. Presentation of participants. Presentation of } \\
\text { the programme and the Nordic project }\end{array}$ \\
\hline KI. $15.30-16.00$ & Coffeebreak \\
\hline KI. $16.00-17.00$ & $\begin{array}{l}\text { Short presentation of the project group and the status of nature interpretation in } \\
\text { the Nordic countries }\end{array}$ \\
\hline KI. $17.00-18.00$ & $\begin{array}{l}\text { Nature Interpretation and sustainable development. Presentation from one of our } \\
\text { guest lecturer Søren Breiting, Denmark }\end{array}$ \\
\hline KI. $18.00-19.00$ & Dinner/Restaurang Hov \\
\hline KI. $19.00-20.00$ & $\begin{array}{l}\text { Nature Interpretation and sustainable development.Presentation from guest } \\
\text { lecturer Lili-Ann Wolff, Finland }\end{array}$ \\
\hline KL. $20-20.30$ & Workshop Groups meet \\
\hline KI. 20.30 & Campfire \\
\hline
\end{tabular}


Tues. $18^{\text {th }}$ Sep.

\begin{tabular}{|c|c|}
\hline KI. $7.30-8.30$ & Breakfast/Restaurang Hov \\
\hline KI. $8.30-8.45$ & Start of the day, practical info and a song \\
\hline KI. 8.45-9.30 & Working in groups \\
\hline KI. $9.30-10.30$ & Tour of Jamtli \\
\hline KI. 10.30-10.45 & Coffeebreak \\
\hline KI. $10.45-12.30$ & Working in groups \\
\hline KI. $12.30-13.30$ & Lunch \\
\hline KI. $13.30-15.30$ & Working in groups \\
\hline KI. $15.30-16.00$ & Coffeebreak \\
\hline KI. 16.00 & Søren og Lill-Ann Wolff presents some of their reflections upon the workshop \\
\hline KI. $17.00-18.00$ & Working in groups \\
\hline KI. $18.00-19.00$ & Dinner/Restaurang Hov \\
\hline KI. 19.00 & Nordic Night \\
\hline \multicolumn{2}{|l|}{ Wedn. $19^{\text {th }}$ Sep. } \\
\hline KI. $7.30-8.30$ & Breakfast /restaurang Hov \\
\hline KI. $8.30-8.45$ & Start of the day, practical info and a song \\
\hline KI. $8.45-10.00$ & Working in groups \\
\hline KI. 10.00 & Coffeebreak \\
\hline KI. 10.30 & Joint session:The result of the workshop, evaluation, networking and goodbye \\
\hline KI. 12.30 & Lunch /restaurang Hov \\
\hline KI. 13.30 & Departure \\
\hline
\end{tabular}




\section{Appendix D/Bilag D}

\section{Working in the groups}

There should be 5 persons in each group. Person A presents its example and Person B make the interview/help on the way. Person C, D and $\mathrm{E}$ are listening.

\section{$10 \mathrm{~min}$. for presentation and interview}

Person A, who described the example tells briefly about his/her example. Tell something that can complement the written example. Person B can ask the following questions: In what way does example show how you try to give children and young people good experiences in nature? How do you create a good setting in your activity? How do you ask questions to the participants, so it causes them to reflect on their experiences of nature and understanding of nature?

\section{0 min.of reflections in the group}

Person C-E together talk together. It is important that the group does not speak directly to the person who has been interviewed, but have a mutual conversation where they think out loud about what they have heard. Ways to talk to would be to start the conversation out of these ways:

- I wonder if she (Person A) have thought of ...?

- I wonder if it would make sense for xx that ...?

- What she says makes me think of ...!

- I get the idea that ...!

- I wonder how $\mathrm{xx}$ think about this?

- It amazes me that ...!

- I wonder where it brings xx going to ...?

- Let us imagine that ...!

\section{0 min. for final thoughts between Person $A$ and $B$}

Person B can now target Person A and ask for the thoughts she now makes on her example and in what way, she sees that the example can be further developed. 
$5 \mathrm{~min}$. for own reflections and notes (all)

Everyone gets $5 \mathrm{~min}$. to themselves to write down their thoughts about what they have heard and learned. Think of your own example and how new thought may change it. 
Nordic Council of Ministers

Ved Stranden 18

DK-1061 Copenhagen K

www.norden.org

Nature Interpretation for Children and Young People

in the Nordic Countries

This TEMA-Nord report is a result of a one-year project with all of the Nordic countries participating. The primary goal of the project has been to collect, develop and mediate a series of good examples of how nature interpretation, aimed at children and young people, can encourage children's understanding of nature, and inspire them to involve themselves with questions on humans nature and thus help contribute to sustainable development. Several issues should be considered when planning nature interpretation activities if nature interpretation aims to lead to sustainable development. These points of view are concerned especially with how nature interpreters can encourage children and young people to take ownership, to be involved with their body and mind, and to reflect and put the experience and the activities in nature into a wider context.

TemaNord 20xx:xxx

ISBN 978-92-893-2549-3

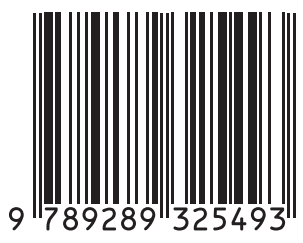

